UNIVERSIDADE DE SÃO PAULO

FACULDADE DE ECONOMIA, ADMINISTRAÇÃO E CONTABILIDADE DE RIBEIRÃO PRETO

DEPARTAMENTO DE CONTABILIDADE

PROGRAMA DE PÓS-GRADUAÇÃO EM CONTROLADORIA E CONTABILIDADE

ROGIENE BATISTA DOS SANTOS

\title{
How do reputation risks affect powerful taxp(l)ayers' behavior?
}

ORIENTADOR: Prof. Dr. Amaury José Rezende

COORIENTADOR: Prof. Dr. Fernando Pigeard de Almeida Prado

Ribeirão Preto

2020 
UNIVERSIDADE DE SÃO PAULO

FACULDADE DE ECONOMIA, ADMINISTRAÇÃO E CONTABILIDADE DE RIBEIRÃO

PRETO

DEPARTAMENTO DE CONTABILIDADE

PROGRAMA DE PÓS-GRADUAÇÃO EM CONTROLADORIA E CONTABILIDADE

ROGIENE BATISTA DOS SANTOS

\section{How do reputation risks affect powerful taxp(l)ayers' behavior?}

Tese apresentada ao Programa de Pós-Graduação em Controladoria e Contabilidade da Faculdade de Economia, Administração e Contabilidade de Ribeirão Preto da Universidade de São Paulo para a obtenção do grau de Doutor em Ciências. Versão corrigida. A versão original está disponível na FEA-RP/USP.

ORIENTADOR: Prof. Dr. Amaury José Rezende

COORIENTADOR: Prof. Dr. Fernando Pigeard de Almeida Prado

Ribeirão Preto

2020 
Prof. Dr. Vahan Agopyan

Reitor da Universidade de São Paulo

Prof. Dr. André Lucirton Costa

Diretor da Faculdade de Economia, Administração e Contabilidade de Ribeirão Preto

Profa Dra Adriana Maria Procópio de Araujo

Chefe do Departamento de Contabilidade

Prof. Dr. Amaury José Rezende

Coordenador do Programa de Pós-Graduação em Controladoria e Contabilidade 
Autorizo a reprodução e divulgação total ou parcial deste trabalho, por qualquer meio convencional ou eletrônico, para fins de estudo e pesquisa, desde que citada a fonte.

O presente trabalho foi realizado com apoio da Coordenação de Aperfeiçoamento de Pessoal de Nível Superior - Brasil (CAPES) - Código de Financiamento 001.

Santos, Rogiene Batista dos

How do reputation risks affect powerful taxp(l)ayers' behavior?, Ribeirão Preto, 2020. 84 p. ; $30 \mathrm{~cm}$

Tese apresentada à Faculdade de Economia, Administração e Contabilidade de Ribeirão Preto

Área de concentração: Controladoria e Contabilidade

Orientador: Prof. Dr. Amaury José Rezende.

Coorientador: Prof. Dr. Fernando Pigeard de Almeida Prado .

1. Tax avoidance. 2. Game theory. 3. Financial institutions. 4. Propensity Score Matching. 


\section{How do reputation risks affect powerful taxp(l)ayers' behavior?}

Tese apresentada ao Programa de Pós-Graduação em Controladoria e Contabilidade da Faculdade de Economia, Administração e Contabilidade de Ribeirão Preto da Universidade de São Paulo para a obtenção do grau de Doutor em Ciências. Versão original. Área de concentração: Controladoria e Contabilidade

Aprovada em:

\section{Banca examinadora}

Prof. Dr: Instituição:

Julgamento: Assinatura:

Prof. Dr:

Julgamento:

Prof. Dr:

Julgamento:
Instituição:

Assinatura:
Prof. Dr:

Julgamento:
Instituição:

Assinatura:
Prof. Dr:

Julgamento:
Instituição:

Assinatura: 


\section{AGRADECIMENTOS}

Agradeço, primeiramente, a Deus por ter sido minha força e refúgio durante esta jornada.

Aos meus pais, Roberto e Gicelda, por terem me dado o dom da vida.

Às minhas irmãs, Rogilene e Rosângela, pelo apoio incondicional.

À minha avó Maria pelas palavras de sabedoria.

Ao meu orientador, Prof. Dr. Amaury José Rezende, por ter me mostrado a importância do trabalho duro e consistente.

Ao meu coorientador, Prof. Dr. Fernando Pigeard de Almeida Prado, por ter me apresentado o mundo encantador da teoria dos jogos.

Ao meu supervisor do doutorado-sanduíche no MIT, Prof. Dr. Rodrigo Verdi, por ter extraído o melhor de mim desde o dia que nos conhecemos.

Ao Prof. Dr. Gabriel Pündrich pelo suporte durante a minha passagem pelo MIT.

À Prof ${ }^{\mathrm{a}} \mathrm{Dr}^{\mathrm{a}}$ Maísa Ribeiro por não ter permitido que eu me sentisse sozinha.

Aos coordenadores do LEPES, Prof. Dr. Daniel Domingues Santos e Prof. Dr. Luiz Guilherme Dácar da Silva Scorzafave, por sempre me incentivarem a ir além.

Ao Prof. Dr. Carlos Yorghi Khoury, por ter visto em mim o que nem eu mesma via.

Aos meus colegas do grupo de pesquisa NECCT pelas preciosas contribuições.

Aos meus colegas do doutorado pelo apoio.

Agradeço, em especial, aos meus colegas: Henrique Velasco, Bruna Alves e Ricardo Vale por me auxiliarem com a parte econométrica desta pesquisa e ao Marcelo Domingues por sempre ter um conselho certo na hora certa.

A todo o corpo de funcionários da FEA-RP.

A todos os professores que passaram por minha vida e que contribuíram para que eu chegasse até aqui. 
"Dificuldades preparam pessoas comuns para destinos extraordinários."

"Hardships often prepare ordinary people for an extraordinary destiny."

C.S. Lewis 


\section{RESUMO}

SANTOS, Rogiene Batista dos. (2020). Como os riscos de reputação afetam o comportamento dos grandes contribuintes (jogadores)?. 2020. 84 f. Tese (Doutorado em Controladoria e Contabilidade) - Faculdade de Economia, Administração e Contabilidade de Ribeirão Preto, Universidade de São Paulo, 2020.

O presente estudo investiga as práticas de planejamento tributário realizadas por instituições financeiras. Há duas principais motivações neste estudo: uma teórica e outra empírica. A primeira diz respeito à modelagem teórica baseada na teoria dos jogos para analisar planejamento tributário de bancos. A segunda motivação refere-se à investigação dos resultados por meio da análise empírica dos dados. Este estudo é composto por duas partes. A primeira parte propõe um modelo teórico baseado na teoria dos jogos que considera a interação do IRS com dois tipos de contribuintes: Complexos e Simples, Bancos e Não-bancos, respectivamente. Quando se considera que os custos de reputação são similares para estes dois grupos, encontrou-se que, no equilíbrio, Bancos são mais agressivos ao praticar planejamento tributário. Porém, ao considerar que os Bancos têm maiores custos de reputação, encontramos que Não-bancos são mais agressivos. Ao realizar a análise da estática comparativa nós encontramos que os Bancos se beneficiam quando a multa aumenta. A solução é aumentar a multa e o custo de reputação deles, simultaneamente. A segunda parte deste estudo, testa o primeiro resultado do modelo teórico que mostra que Bancos não são tão agressivos ao praticar planejamento tributário. Para isso, utilizou-se uma amostra de dados das empresas americanas de capital aberto, para o período de 2000-2018, totalizando 110.030 observações. Os resultados empíricos mostram que não há diferença na prática de planejamento tributário entre empresas financeiras e empresas de outros setores. Economicamente, não ter confirmado a hipótese de pesquisa que empresas financeiras praticam menos evasão fiscal que empresas de outros setores implica que talvez os custos de reputação tenham pouco efeito sobre as práticas de evasão fiscal das instituições financeiras. É possível que o efeito dos custos de reputação não afete diretamente as empresas financeiras. Portanto, o seu efeito seria marginal. Este estudo, composto por duas partes, fornece evidências para uma melhor compreensão acerca das práticas de planejamento tributário e dos custos de reputação de tais práticas para instituições financeiras. Os resultados encontrados são relevantes para pesquisadores e legisladores.

Palavras-chave: Planejamento tributário. Teoria dos jogos. 3. Instituições financeiras. 4. Propensity Score Matching. 


\begin{abstract}
SANTOS, Rogiene Batista dos. (2020). How do reputation risks affect powerful taxp(l)ayers' behavior?. 2020. 84 p. Tese (Doutorado em Controladoria e Contabilidade) - Faculdade de Economia, Administração e Contabilidade de Ribeirão Preto, Universidade de São Paulo, 2020.

This study investigates the practices of tax avoidance of financial institutions. There are two main motivations for this study: one theoretical and other empirical. The first relates to theoretical modeling based on game theory to analyze tax avoidance of banks. The second involves to the examination of the results of the theoretical model by, empirically, analyzing a database. This study is composed of two parts. The first part proposes a theoretical model based on game theory that considers the interplay of the IRS and two types of taxpayers: Complex and Simple (Banks and Non-banks, respectively). When considering that the reputation costs are similar for these two groups, we find that, at the equilibrium, Banks are more aggressive than Non-banks in practicing tax avoidance. However, when considering that Banks have higher reputation costs, we find that Non-banks are more aggressive. By performing comparative statics we find that Banks benefit when the fine increases. A solution is to increase the reputation cost and fine, simultaneously. The second part of this study, empirically, tests the first result of the theoretical model, showing that Banks are not so aggressive when practicing tax avoidance. For this purpose, we use a sample composed by U.S. public firms, covering the period 2000-2018, totaling 110,030 firm-years. The empirical results show no difference in the level of tax avoidance between financial companies and companies from other sectors. Economically, not having confirmed the research hypothesis that financial companies practice less tax avoidance than companies from other sectors implies that perhaps reputation costs have little effect on financial institutions' tax avoidance practices. It is possible that the effect of reputation costs does not directly affect financial companies. Therefore, its effect would be marginal. This study provides evidence for a better understanding of tax avoidance and the reputation costs of this practice of financial institutions. The results obtained are relevant for academics and policymakers.
\end{abstract}

Keywords: Tax avoidance. Game theory. 3. Financial institutions. 4. Propensity score matching. 


\section{List of Figures}

Figure 2.1 - Summary of the results . . . . . . . . . . . . . . . 23

Figure 3.1 - Propensity score matching graph: Sarbanes-Oxley Act (SOX): GAAP ETR . 53

Figure 3.2 - Graph before matching: Sarbanes-Oxley Act (SOX): GAAP ETR . . . . . 54

Figure 3.3 - Graph after matching: Sarbanes-Oxley Act (SOX): GAAP ETR . . . . . . . 54

Figure 3.4 - Propensity score matching graph: Sarbanes-Oxley Act (SOX): CASH ETR . 58

Figure 3.5 - Graph before matching: Sarbanes-Oxley Act (SOX): CASH ETR _ . . . . 59

Figure 3.6 - Graph after matching: Sarbanes-Oxley Act (SOX): CASH ETR . . . . . . . 59 


\section{List of Tables}

Table 3.1 - Sample selection - Panel A . . . . . . . . . . . . . . . . . 32

Table 3.2 - Sample selection - Panel B . . . . . . . . . . . . . . . . 32

Table 3.3 - Sample selection Panel C . . . . . . . . . . . . . . . . . 33

Table 3.4 - Variable measurement . . . . . . . . . . . . . . . . 36

Table 3.5 - Descriptive statistics . . . . . . . . . . . . . . . . . 38

Table 3.6 - Pearson (below) and Spearman (above) correlations of tax avoidance measures 39

Table 3.7 - Difference of means . . . . . . . . . . . . . . . . . 40

Table 3.8 - Tax avoidance of Financial and Non-financial firms (GAAP ETR) . . . . . . 43

Table 3.9 - Tax avoidance of Financial and Non-financial firms (CASH ETR) . . . . . . 44

Table 3.10-Quantile regression GAAP ETR . . . . . . . . . . . . . . . . . 48

Table 3.11-First-stage prediction model of Propensity Score Matching (GAAP ETR) . . 50

Table 3.12-Propensity Score Matching sample (GAAP ETR) . . . . . . . . . . . . . 51

Table 3.13-Matching - Sarbanes-Oxley Act (SOX): GAAP ETR . . . . . . . . . . . 52

Table 3.14-First-stage prediction model of Propensity Score Matching (CASH ETR) . . 55

Table 3.15-Sample of Propensity Score Matching (CASH ETR) . . . . . . . . . . . . 56

Table 3.16-Matching - Sarbanes-Oxley Act (SOX): CASH ETR . . . . . . . . . . . 57 


\section{Contents}

A GENERAL INTRODUCTION . . . . . . . . . . . . . . 1

2.2.1 Game theory and tax avoidance . . . . . . . . . . . . 5

2.2.2 Game theory and reputation . . . . . . . . . . . . . . . . 5

2.2.3 Asymmetric information and signaling theory . . . . . . . . . 6

2.2.4 Financial institutions . . . . . . . . . . . . . . 6

2.2.5 Game theory models in corporate finance . . . . . . . . . . . . . 7

$2.3 \quad$ An interactive tax avoidance model . . . . . . . . . . . . . . . 8

2.3.1 Formal model . . . . . . . . . . . . . . . . . . 10

$2.4 \quad$ Results . . . . . . . . . . . . . . . . . . 14

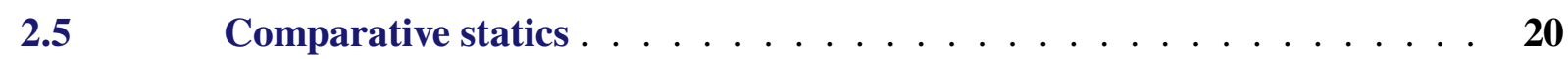

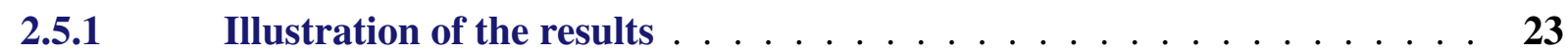

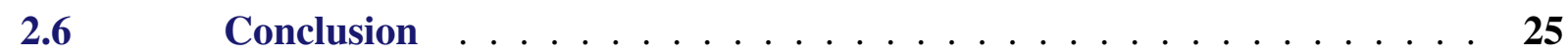

3 DO FINANCIAL INSTITUTIONS PRACTICE LESS TAX AVOIDANCE THAN OTHER COMPANIES? ................. 26

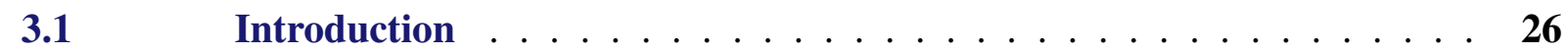

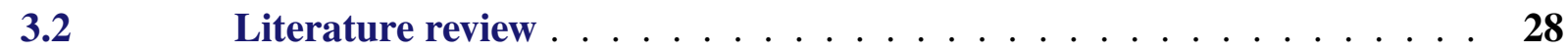

3.2.1 Tax avoidance and agency theory $\ldots \ldots \ldots \ldots$

3.2.2 Tax avoidance and corporate governance . . . . . . . . . . . . . 29

3.2.3 Tax avoidance and reputation . . . . . . . . . . . . . 30

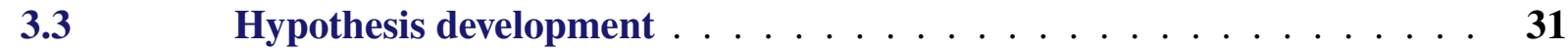

$3.4 \quad$ Sample and research design . . . . . . . . . . . . . . 31

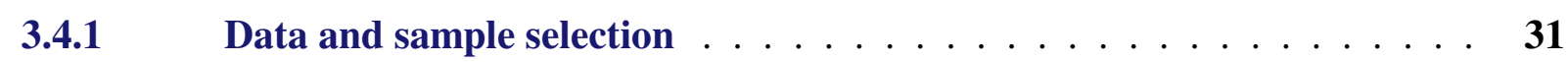

3.4.2 $\quad$ Research design . . . . . . . . . . . . . . . . . 33

$3.5 \quad$ Empirical analysis $\ldots \ldots \ldots \ldots \ldots \ldots \ldots$

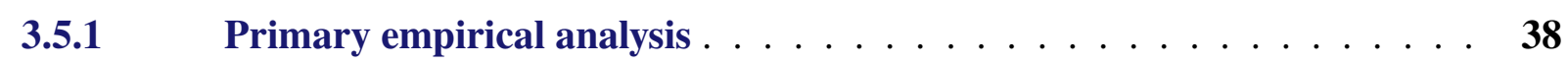

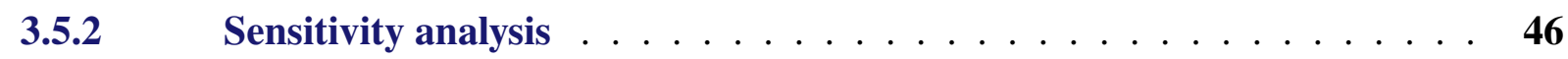

3.5.3 Additional analysis $\ldots \ldots \ldots \ldots \ldots$

$3.6 \quad$ Conclusion $\ldots \ldots \ldots \ldots \ldots \ldots \ldots$

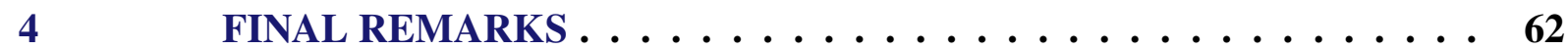


Bibliography $\ldots \ldots \ldots \ldots \ldots \ldots$

$\begin{array}{ll}\text { Appendices } & 71\end{array}$

Methodological procedures $\ldots \ldots \ldots \ldots \ldots \ldots$ 


\section{A GENERAL INTRODUCTION}

Many countries face tax avoidance problems, and according to the International Monetary Fund (IMF), this causes lost revenue of some $\$ 600$ billion each year. The main countries that face this problem are United States (losses of $\$ 188.8$ billion annually), China ( $\$ 66.8$ billion), Japan ( $\$ 46.8$ billion) and India ( $\$ 41.2$ billion).

This issue is relevant and demands solutions. Thus, both governments and academics tried to find solutions and ways to inhibit this behavior. The US Internal Revenue Service (IRS) has published some results of its studies about tax compliance (Plumley, 1996; Ritsema, Thomas, $\&$ Ferrier, 2003). On the other hand, some studies performed by academics have investigated the problem of tax avoidance by proposing theoretical models based on game theory (Allingham \& Sandmo, 1972; Graetz, Reinganum, \& Wilde, 1986; Greenberg, 1984).

Empirically, other studies have addressed this problem from the perspective of agency theory (Armstrong et al., 2015; Chen \& Chu, 2005; Crocker \& Slemrod, 2005; Khan et al., 2017; Slemrod, 2004). Others have analyzed this topic from the standpoint of corporate governance (Desai et al., 2007; Hoi et al., 2013; Minnick \& Noga, 2010). This topic has also been examined from the viewpoint of reputation (Chyz, 2013; Chyz \& Gaertner, 2018; Dyreng, Hanlon, \& Maydew, 2010; Rego \& Wilson, 2012)

In all these previous studies about tax avoidance, the banking was excluded from the sample. However, this sector is very important local and global economies. The economic crisis of 2002 highlighted the importance of better understanding how banks work. Many studies have investigated the reputation of financial institutions (Barakat, Ashby, Fenn, \& Bryce, 2019; Baselga-Pascual et al., 2018; Fiordelisi et al., 2013; Lee \& Masulis, 2011; Ruiz, Esteban, \& Gutiérrez, 2014). More recently, some authors have studied tax avoidance of financial institutions (Agyei et al., 2019; Hasan, Hoi, Wu, \& Zhang, 2014; Kovermann, 2018; Moore \& Xu, 2018).

The scarcity of studies analyzing tax avoidance of financial institutions leaves a gap to be filled. It is intuitive that as banks make complex transactions and they are large, thus they have more incentives to be more aggressive when practicing but the previous studies did not explain why banks are not as aggressive as they are supposed to be. We fill this gap by answering to the research question: How do reputation risks affect powerful taxp(l)ayers' behavior?

Therefore, there are two motivations for answering this question. The first to apply game theory to model the tax avoidance of financial institutions. This theory is useful to model the behavior of players that act strategically. The second refers to the empirical investigation of the results obtained from the theoretical model. By examining the theoretical results empiricaly we can show that the theoretical model can be applicable to the real context. For these purposes, the study is divided into in two parts.

In the first part, we propose a theoretical model based on game theory that analyzes the 
interplay among the IRS and two types of taxpayers: Complex and Simple (Banks and Non-banks, respectively). When we consider that the reputation cost is similar for these two groups, we find that, in equilibrium, Banks are more aggressive when practicing tax avoidance than Non-banks. However, when we consider that Banks have higher reputation costs, we find that, in equilibrium, Non-banks are more aggressive. By analyzing the comparative statics we find that Complex taxpayers (Banks) benefit when the fine increases. However, Complex taxpayers are sensitive to reputation cost, which restrains them from engaging in tax avoidance. A solution is to increase the fine and the reputation cost, simultaneously. The reputation cost can be increased by increasing the disclosure of tax avoidance cases.

The second part, empirically, tests the result obtained in the theoretical model according to which banks are not that aggressive when practicing tax avoidance. To date, we did not find studies analyzing the interaction of these two groups with the IRS. Moreover, the literature does not indicate whether there are differences in the level of tax avoidance between Financial institutions and Non-financial institutions. Thus, this leaves a gap to fill. We use a sample of all U.S. public firms and various methods to reach the objective of this part. By performing OLS regressions and panel data with with robust standard errors, we find that statistically there is no difference between financial companies and companies from other sectors. One explanation for this result is that financial institutions have higher reputation costs. Therefore, they practice the same level of tax avoidance as other companies. In this part, we also analyze the impact of the Sarbanes-Oxley Act and conclude that it forced the public companies to be less aggressive when practicing tax avoidance.

This study contributes to the literature in many ways. Unlike previous studies, we propose a theoretical model based on game theory that analyzes the interplay among IRS, Banks and Nonbanks. This study also provides evidence for a better understanding of tax avoidance of Financial and Non-financial companies. Moreover, this study adds to the literature on tax avoidance by bringing evidence about the reputation costs of financial institutions of practicing tax avoidance.

This study has two parts. Although each part has a specific objective, each one is connected with the others. However, these parts compose a complete research. The purpose of this General Introduction section is to provide an overview of the study and our motivations, as well as to present our contributions. Below we present the development of each part. Finally, we present the main conclusions. 


\section{A GAME THEORY APPROACH TO TAX AVOIDANCE OF BANKS}

This section proposes a theoretical model that reconciles the assumptions of game theory and the reputation costs of practicing tax avoidance by banks. The previous theoretical models that analyze tax avoidance are broad and ignore the reputation costs. Thus, our mission in this part is to propose a specific model by analyzing tax avoidance of banks. For this, we consider the interplay of two important parameters: the ability of banks to influence the success of IRS audits and reputation costs. Therefore, by developing a game theory model that considers the interplay of these two types of taxpayer and the IRS, it is possible to understand their behavior and the level of tax-avoidance in the equilibrium. The IRS faces two types of taxpayers: Complex and Simple (Banks and Non-banks, respectively). In the first moment of the analysis, we consider that the differences between the reputation cost of Complex and Simple taxpayers are negligible.

Thus, we find that in equilibrium, banks are more aggressive when practicing tax avoidance than Non-banks. However, at the second moment, when we consider that banks have higher reputation costs than Non-banks, this result changes. Since banks are large, they receive more attention from the IRS, society and the media, and consequently they have higher reputation costs. We find that in equilibrium, Non-banks are more aggressive. This happens because practicing tax avoidance is more costly for Banks than for Non-banks. We conclude that the only parameters that affect the Nash equilibria are: the audit cost benefits, the probability of success of the audit for each group and the reputation costs.

The results obtained in this part of the study contribute to the literature in many ways. Unlike previous studies, we propose a theoretical model specifically analyzing the banking sector. We also extend previous models by considering reputation costs. Finally, the theoretical model can help improve the tax collection policy and promote greater tax justice.

\subsection{Introduction}

Many countries face the problem with tax avoidance causing billions of dollars in revenue shortfalls ${ }^{1}$. The International Monetary Fund (IMF) estimates a huge loss of about $\$ 600$ billion profit each in forgone revenue each year globally. A new article published by UNU-WIDER ${ }^{2}$ analyzed the issue more closely at the national level and showed that the United States is the country that loses the most, in absolute terms, from tax avoidance. The data show that every year, the U.S. loses about $\$ 189$ in corporate taxes, or about $1.13 \%$ of gross domestic product (GDP). China loses about $\$ 66.8$ billion, while Japan is also affected to the tune of $\$ 47$ billion due to tax avoidance. The IMF also showed that the Organization for Economic Cooperation and

\footnotetext{
https://www.statista.com/chart/8668/the-global-cost-of-tax-avoidance/

2 https://www.wider.unu.edu/publication/estimating-tax-avoidance
} 
Development (OECD) countries typically lose about $2 \%$ to $3 \%$ of their total annual tax revenue. However, this loss is bigger percent-wise in countries with low income.

This problem has puzzled both government and academics. Because of that, the U.S. Internal Revenue Service (IRS) published some results of its studies about tax compliance (Plumley, 1996; Ritsema, Thomas, \& Ferrier, 2003). Several academics have analyzed this problem, including, from the perspective of game theory (Allingham \& Sandmo, 1972; Graetz, Reinganum, \& Wilde, 1986; Greenberg, 1984). However, both the causes and the appropriate responses to this problem remain controversial.

The game theory is a theory that models the economic behavior among players that act strategically. According to Samuelson (2016), game theory can be applied in many areas, such as financial studies, where it has been used to propose that dividends are signals (Allen \& Michaely, 1995; Black, 1972; Fama \& Babiak, 1968; Lintner J., 1956).

Many other studies have used game theory to understand reputation (Sloof \& Winden, 2000; Taleb \& Sandis, 2014; Warin, De Marcellis-Warin, Sanger, Nembot, \& Mirza, 2015a). When there is asymmetric information, practices or actions are interpreted as signals to other companies, government and investors. These signals can affect companies' reputation. Spence (1973) first proposed signaling theory based on asymmetric information.

Unfortunately, the existing economic analysis of tax avoidance provides an incomplete explanation for this problem. One reason for this is that the previous studies do not consider the reputation cost of tax avoidance for the companies that practice it. Moreover, these studies use a general theoretical model to explain tax avoidance. Thus, here we propose a theoretical model that analyzes the interplay among the IRS, Banks and Non-banks. The banking system has a great importance for both the local and global economy. Many studies have investigated the banking system (Adrian \& Shin, 2009; Barth, Caprio, \& Levine, 2001; Georgescu \& Jeflea, 2015; Wray, 2010). A good review article of banking theory is Bhattacharya \& Thakor (1993).

According to the literature, since banks as a rule are large, more capable of engaging in tax avoidance. However, they also have higher reputation costs when doing this. For instance, in February 2015, The Guardian ${ }^{3}$ reported that a scandal about systematic practice of tax avoidance caused huge damage to the reputation of HSBC. Thus, in this part we propose a specific theoretical model based on game theory that models tax avoidance of banks.

This part many contributions. Unlike the previous studies, we propose a theoretical model that analyzes the interplay among the IRS, Banks and Non-banks. We also extend previous models by considering reputation costs. Moreover, the theoretical model can contribute by improving the tax collection policy and promotion of greater tax justice.

The remainder of this section is structured as follows: Section 2.2 presents the literature review, Section 2.3 describes the theoretical model, Section 2.4 presents the results, Section 2.5 
shows the comparative statics; and Section 2.6 presents some relevant concluding remarks.

\subsection{Literature review}

\subsubsection{Game theory and tax avoidance}

Allingham \& Sandmo (1972) were the first academics to try to shed light on the tax avoidance puzzle. For this, they examined some features that involve the decision to evade taxes. In the same sense, Greenberg (1984) proposed an optimal auditing scheme for tax authorities that face given tax and penalty functions and a given budget constraint. Graetz, Reinganum \& Wilde (1986) showed that when considering enforcement in the theoretical analysis one can better understand the role of law enforcement in this game.

In contrast, some studies have analyzed this problem from the perspective of incentives (Holt \& Laury, 2002), while others have investigated it based on the view of specialists (Clemente \& LÃrio, 2018; Lipatov, 2012). Coricelli, Rusconi, \& Villeval (2014) investigated the problem of tax avoidance by considering emotions in this process. Dalamagas (2011) used a dynamic approach to solve the puzzle. Carfì \& Musolino (2015), in turn, proposed a theoretical model that investigates the interplay between the state and taxpayers, by using a realistic probability approach to examine evasion strategy.

\subsubsection{Game theory and reputation}

Many studies have used game theory to understand reputation. For example, Gordon (1989) proposed a model using non-pecuniary costs of evasion to reconcile theory and evidence that some individuals do not evade taxes because of reputation costs. To investigate how people take risks, Taleb \& Sandis (2014) proposed a model considering the morality underpinning the decision of taxpayers to evade taxes due to the harm caused to other people.

On the other hand, Sloof \& Winden (2000) proposed a theoretical model to analyze lobbying and pressure. According to them, lobbying and pressure are strategies to transmit information to policymakers. They found that pressure imposes costs on policymakers and that lobbying cannot be substituted in place of pressure. They concluded that pressure is a way to build reputation and lobbying works to maintain it. From social perspective, Warin et al. (2015) analyzed reputation by using a game theory approach to understand the relation between corporate reputation and social media. Litina \& Palivos (2016) theoretically explained the relation between political corruption and tax evasion when countries do not consider social values.

Through empirical testing, Fiordelisi, Soana, \& Schwizer (2013) investigated what determines banks' reputation. For this, they calculated the reputation risk for European and American banks covering the period from 2003 to 2008 . They found two main results. First, they showed 
that reputation harm increases as profits and size increase. Second, they demonstrated an inverse relation between capital invested plus intangible assets and reputation damage.

\subsubsection{Asymmetric information and signaling theory}

When there is asymmetric information, practices and actions act as signals, which can affect reputation. Incomplete information has been the topic of various studies (Akerlof, 1970; Harsanyi, 1967; Mitzkewitz \& Nagel, 1993; Nachbar, 2001). Other studies have focused on the informational asymmetries in financial institutions (Leland H. E \& Pyle, 1977; Myers \& Majluf, 1984).

Signaling theory is useful for describing the behavior when two parties can access different levels of information. Spence (1973) was the first to propose signaling theory based on asymmetric information. Subsequently, other studies were carried out to shed light of the role of signaling in the market. In the same direction, Cho \& Kreps (1987) proposed signaling games using stable equilibria. Their demonstration showed that their tests were very powerful in many applications and they produced reasonable results, in particular, demonstrations in signaling games. According to Morris (1987), signaling and agency theories are not competing theories. He demonstrated how these theories can be reconciled.

Milde \& Riley (1988) analyzed signaling in credit markets. They showed that the private information of borrowers in the market for loans is determined by screening. They found that banks consider this information in setting the interest rates on the loans. From the perspective of the adverse selection theory, Adelino, Gerardi \& Hartman-Glaser (2019) claimed that a central result of this theory is that informed sellers can use information to increase prices. To consolidate the studies in this topic, Connelly, Certo, Ireland \& Reutzel (2011) carried out a literature review.

\subsubsection{Financial institutions}

The previous models of tax avoidance are generic so, here propose a theoretical model of tax avoidance by financial institutions. This sector some particularities, which can cause the previous theoretical models not applicable to it. Many studies have investigated the banking system, such as, Wray (2010), who analyzed what banks should do and what they actually do. According to him, banks' liabilities are commitments established in advance in order to make payments according to the demands on a certain date or if any contingency occurs.

In contrast, Barth et al. (2001) discussed the differences between countries' financial systems, ranging from the simplest to the most sophisticated and from the most fragile to the most stable. According to them, several studies have shown a relationship between the financial system and economic growth. From the perspective of regulation, Adrian \& Shin (2009) investigated the "shadow banking system? and the impacts of the regulation of financial institutions. They argued that the recent financial crisis showed that the shadow banking system had great importance in 
the financial system.

Georgescu \& Jeflea (2015) analyzed the particularity of the banking information system. They focused on the features of bank information systems by analyzing the integrative and multidisciplinary elements that involve economic computing, organizational management, marketing and other elements. Bhattacharya \& Thakor (1993) presented a review of contemporary banking theory.

\subsubsection{Game theory models in corporate finance}

Gamee theory has been used in many financial studies, such as to propose that dividends act as signals (Allen \& Michaely, 1995; Black, 1972; Fama \& Babiak, 1968; Lintner J., 1956). Over the years, companies have used about half of their profits to pay dividends. Thus, many investors who receive these dividends pay large amounts of taxes.

Other studies have used game theory to understand capital structure (Harris \& Raviv, 1991; Myers, 1984; Ross, 1977). The capital structure tradeoff theory has been a basic theory for many years. Even though it has provided a better explanation of firms' choices than the initial dividend models, the theory does not fully explain the reasons for the theory does not explain the practical reasons for bankruptcy costs.

Game theory also has been useful to analyze the market for corporate control (Bradley, Desai, \& Kim, 1988; Fishman, 1988; Grossman \& Hart, 1980; Hirshleifer, 1995; Jennings \& Mazzeo, 1993). The concept of the market for corporate control was first developed by Manne (1965). According to him, for resources to be used efficiently, companies need to be managed by the best prepared managers.

Several studies have used game theory to model initial public offerings (IPOs) (Franklin Allen \& Faulhaber, 1989; Ibbotson \& Ritter, 1995; Logue, 1973; Rock, 1986; Ruud, 1993). For instance, Ibbotson \& Ritter (1995) they found that for the period 1960 to 1992 there was an average increase in stock prices of $15.30 \%$ on the first day of trading. The reason for this high return of IPOs has long been a challenge to explain based on efficient market theory.

Finally, game theory has been used to understand intermediation (Chari \& Jagannathan, 1988; Diamond, 1984; Diamond \& Dybvig, 1983; Stiglitz \& Weiss, 1981; Thakor, 1996). In general, banks and other financial intermediaries are considered as acting to reduce transaction costs. According to Diamond \& Dybvig (1983), the initial descriptions of banks' behavior were relatively limited. This field has been drastically altered by the modeling techniques.

All the theories that previous studies used to explain the practices of tax avoidance cannot explain completely how firms decide to engage in tax avoidance. Thus, by using game theory we try to provide a deeper understanding how companies decide to practice it. 


\subsection{An interactive tax avoidance model}

In 1986, Graetz, Reinganumand \& Wilde (1986) proposed a tax compliance game. Unlike previous models of tax avoidance, they explicitly included a law enforcement agency, more specifically, the Internal Revenue Service (IRS). They made a substantial contribution to the literature because they also considered the actions involved in the collection process. Previous studies of IRS policies and actions had treated them as exogenous parameters. According to them, the law enforcement power of the IRS had a positive effect on tax revenue.

Since the publication, 36 years ago, Graetz, Reinganumand \& Wilde (1986)'s results have been widely cited in the literature. However, their model may not apply to all cases nowadays, in particular to tax avoidance of financial institutions. Thus, this part of the study proposes a specific model based on game theory to analyze tax avoidance of banks by expanding on the study of Graetz, Reinganumand \& Wilde (1986). We propose and analyze a model that fills the gap in the literature by considering the interplay of two important parameters: the ability of banks to influence the success of IRS audits and the reputation costs of banks.

This contributes to the literature in many ways. We propose a specific theoretical model for banks because previous models may be not applicable to the context of the banking sector due to the many differences in relation to other sectors. We also consider the reputation costs that firms incur when they evade taxes. This is important because the existence and influence of reputation costs have been confirmed in empirical studies. However, no previous model has considered these costs from theoretical point of view. Moreover, after the financial crisis of 2002, the need became evident to better understand how banks work.

The basic assumption here is that all players try to maximize their utility. Consequently, each one chooses the option that maximizes its payoffs. The IRS faces two types of taxpayers: Complex and Simple ones (Banks and Non-banks, respectively). By developing a game theory model that considers the interplay of these two types of taxpayer and the IRS, it is possible to understand their behavior and the level of tax avoidance in equilibrium.

We follow closely the general Graetz, Reinganumand \& Wilde (1986)'s model according to who both taxpayers and the IRS are players of a game having pursuing conflicting goals. The main difference is that in our model we consider two subgroups of taxpayers: Complex and Simple taxpayers, whose true incomes are more likely to be discovered in the audit process more or less likely depend on the complexity of the transactions of them. In addition, we assume that each taxpayer has a subgroup-specific reputation cost whenever if it is reveled to be higher than they declared.

If the taxpayer is not audited or if it is audited but its true income is not discovered, then the taxpayer's report determines its final tax liability; if the taxpayer is audited and its true income is discovered, then its tax liability is computed on the basis of true income, plus any applicable fines, penalties, or interests. 
We assume that there are two types o taxpayers: 1) Big and complex taxpayers; and 2) Small and simple tax payers, here we called 1) Complex; and 2) Simple taxpayers. If a taxpayer is audited, its true income is less likely to be discovered if it is complex rather than simple. As mentioned, we as banks make complex transactions, we consider that they are complex taxpayers. On the other hand, we consider that Non-banks are simple. This is due to the complexity of bank's products (e.g. financial products like complex derivatives offered by financial institutions).

Financial derivatives perform an increasingly common role in corporate tax avoidance.According to Donohoe (2015), the derivatives are an integral part of the global economy, with over-the-counter transactions estimated to be in excess of $\$ 710$ trillion. Thus, in general, derivatives help companies to manage financial risks that threaten revenue, costs of products sold and various expenses. But, as this area is complex and has ambiguous tax legislation, derivatives also generate lucrative tax planning opportunities.

Raskolnikov (2011) points out that the derivatives facilitation mechanism in relation to corporate tax avoidance is largely hidden from society and regulators, because companies rarely reveal such details in their financial reports. With the adoption of IFRS, companies were asked to disclose more information about the use of derivatives; however, this disclosure does not allow a greater understanding of how these financial instruments are used for tax avoidance.

Donohoe (2015) presents four aspects by which derivatives are useful in the process of evading taxes. First, there is extensive ambiguity in the taxation of derivative transactions. Second, the taxation of derivatives is inconsistent, as not all economically comparable transactions receive the same tax treatment. Third, new derivatives are routinely created to meet a variety of financial needs and goals; at the same time, more traditional derivatives are being dissected and repackaged as intriguing new financial products. Finally, a final source of ambiguity stems from the asymmetric tax treatment of the same derivative transaction.

If the true income of a complex taxpayer is discovered, we assume that it will incur in a higher reputation cost ${ }^{4}$ (in addition to the common penalties and interests imposed by the IRS on both types of taxpayers). This is because we are focusing on complex tax payers that are big in the sense that they have more attention from society, the IRS and the media. As consequence, the impact of bad news on the taxpayers stock price is supposed to be larger when the taxpayer is assumed to be big and complex. ${ }^{5}$ For example, Blaufus et. al. (2019) by analyzing 176 tax news items regarding listed German firms over the period from 2003 to 2016, find a negative abnormal returns for tax evasion news. Similarly as in Graetz, Reinganumand \& Wilde (1986), we assume, for simplicity, that there are only two income levels: high and low. A high income taxpayer is

4 Here reputation cost is defined as the various ways of economic and other harm that a firm may experience as a result of damage to its reputation with customers or others. We do not use political costs in this study because they are costs that particular groups external to the firm may be able to impose on the firm as a result of various actions. Thus, reputation costs are wider than political costs.

5 That large firms have higher reputation costs than small ones was already recognized by According to Zimmerman (1983). According to him, large firms are subjected to greater government scrutiny. Consequently, these companies have more reputation costs. 
successfully audited if the IRS detects that the taxpayer's true income is higher than declared. If a high income taxpayer is not successfully audited then the IRS assumes that the taxpayer's income is the declared one. Each type of high income taxpayers, complex or simple, is successfully audited with a certain probability, which is type specific and exogenous. In addition, each type of high income taxpayer incurs a type specific and exogenous reputation cost (valuated monetarily), whenever the IRS detects that the taxpayer's income is higher than declared. ${ }^{6}$ We also we treat income levels (high and low), tax rates, and fines as exogenous parameters of the model as well. The IRS cannot observe the true income. Thus, it plays with incomplete information. When the IRS receives the tax return from the taxpayers, it does not know if they report income truthfully or not. Thus, we assume that the IRS is subject to budget constraints so it always has to evaluate whether it is financially worthwhile auditing firms.

The final conclusion of the model is reached when solving the game and analyzing its Nash equilibria. In this game, the strategy of the IRS is denoted by the probability of auditing and the strategies of Complex and Simple taxpayers are represented by their respective probabilities of tax evasion. A Nash equilibrium in this context is defined as a three dimensional vector of strategies chosen by taxpayers (Complex and Simple) and the IRS that are best responses to one another. Therefore, in Nash equilibrium, neither the IRS nor potential avoiders have incentives to change their strategies. That is, in Nash equilibrium, each player's strategy is optimal. Next we present the formal model.

The reason why we use the concept of equilibrium in this theoretical model is that it will be suggestive of directions and tendencies in the responses of relevant parties in the context of a complex dynamic process. When analyzing these responses, we find a, apparently, counterintuitive resul: an increase in the fine, increases total evasion. This result happens because there is a specific point where the discontinuity occurs. The Laffer theorem may explain this counterintuitive result because it states that increasing tax rates beyond a certain point becomes unproductive, as revenue also decreases (Bender, 1984). Following, we will discuss these results. The next section will present the formal model.

\subsubsection{Formal model}

We denote by $q$ and $1-q$ the proportions of taxpayers with high and low income, respectively. Like Graetz, Reinganumand \& Wilde (1986), we consider only two levels of income: high and low, denoted by $I_{H}$ and $I_{L}$, respectively, where $I_{L}<I_{H}$. The IRS cannot observe taxpayers' incomes. Thus, taxpayers can choose which type of income to declare (high or low). We denote by $T_{H}$ and $T_{L}$ the tax payments owed by high and low income taxpayers, respectively. We assume that $T_{L}<I_{L}, T_{H}<I_{H}$, and $T_{L}<T_{H}$. There are two types of taxpayers, Complex (Banks) and Simple (Non-banks), of which the proportions are $\delta$ and $1-\delta$, respectively. We denote

6 It is well known that news about corporate tax evasion affects negatively the tax evader's stock prices (Blaufus et al., 2019) Needless to say that, depending on size and visibility of the taxpayer, such bad news affect the taxpayer's stock differently. 
by $\gamma_{C}$ and $\gamma_{S}$, the probabilities of audit success of Complex and Simple taxpayers, respectively, where $\gamma_{C}<\gamma_{S}$. If a high-income taxpayer underreports its income and is caught, then it will pay a positive fine $F$, the tax difference $T_{H}-T_{L}$ and a reputation cost $R_{C}$, for Complex, and $R_{S}$ for Simple taxpayers.

The audit process is expensive for the IRS. We denote by $c>0$ the cost of a single audit. We assume that $T_{H}+F-T_{L}>c$; that is, the revenue of successfully auditing a high-income taxpayer that reports low income should exceed the audit cost. We also assume that $T_{L}+F \leq I_{L}$ and $T_{H}+F \leq I_{H}$; the total of taxes plus fines cannot exceed the income of a taxpayer. Finally we assume that the taxpayers that report honestly are never fined and suffer no other costs if they are audited. So far we have presented and discussed all the fixed parameter of the model, which are: the tax levels $\left(T_{H}\right.$ and $\left.T_{L}\right)$, the income levels $\left(I_{H}\right.$ and $\left.I_{L}\right)$, the fine $(F)$, the probabilities of audit success $\left(\gamma_{C}\right.$ and $\left.\gamma_{S}\right)$, the reputation costs $\left(R_{C}\right.$ and $\left.R_{S}\right)$, and the audit cost $(c)$. We now turn to the strategies of taxpayers and the IRS.

We assume that taxpayers that report honestly do not incur any costs when being audited, and low-income taxpayers always report honestly. In this way, a strategy for both Complex and Simple taxpayers with high income is to declare low income with a certain probability when, in fact, they had high income. We denote these probabilities by $\alpha_{C}$ and $\alpha_{S}$ for Complex and Simple taxpayers, respectively.

Bearing in mind that the IRS cannot distinguish a priori between those that declare low income but in fact have high income and those that declare low income and really have low income, the IRS can at most choose a probability $\beta \in[0,1]$ with which it audits a taxpayer that reports low income. In addition, it is assumed that the IRS does not audit taxpayers that report high-income since there is no benefit for the IRS to do so. As a consequence, the model under consideration reduces to a tax evasion game, hereafter denoted by $G$, between Complex and Simple high-income taxpayers and the IRS. The players' strategies of $G$ are $\alpha_{C}, \alpha_{S}$, and $\beta$.

In order to choose $\beta$, the IRS estimates the probability $\mu$ that a taxpayer reporting a low income in fact has high income if performing an audit. Given that Complex and Simple highincome taxpayers declare low income with probabilities $\alpha_{C}$ and $\alpha_{S}$, respectively, this probability is:

$$
\mu=\mu\left(\alpha_{C}, \alpha_{S}\right)=\frac{q\left[\delta \gamma_{C} \alpha_{C}+(1-\delta) \gamma_{S} \alpha_{S}\right]}{q\left[\delta \alpha_{C}+(1-\delta) \gamma_{S} \alpha_{S}\right]+1-q} .
$$

Taking (2.1) into account, the utility function of the IRS is:

$$
\Pi\left(\beta, \alpha_{C}, \alpha_{S}\right)=\beta\left[\mu\left(T_{H}+F-c\right)+(1-\mu)\left(T_{L}-c\right)\right]+(1-\beta) T_{L} .
$$

The first part of this expression is the expected return from auditing minus the audit costs and the second part is the revenue received if no audit is performed.

Let $u$ be taxpayers' utility of money. The utility function of high-income Complex and 
Simple taxpayers can be written as follows:

$$
U_{C}\left(\alpha_{C}, \alpha_{S}, \beta\right)=\alpha_{C}\left[\beta \gamma_{C} u\left(I_{H}-T_{H}-F_{C}\right)+\left(1-\beta \gamma_{C}\right) u\left(I_{H}-T_{L}\right)\right]+\left(1-\alpha_{C}\right) u\left(I_{H}-T_{H}\right),
$$

$$
U_{S}\left(\alpha_{C}, \alpha_{S}, \beta\right)=\alpha_{C}\left[\beta \gamma_{S} u\left(I_{H}-T_{H}-F_{S}\right)+\left(1-\beta \gamma_{S}\right) u\left(I_{H}-T_{L}\right)\right]+\left(1-\alpha_{S}\right) u\left(I_{H}-T_{H}\right)
$$

where

$$
F_{C}=F+R_{C} \quad \text { and } \quad F_{S}=F+R_{S}
$$

In both Equation (2.3) and Equation (2.4), the first part is the utility received by the high-income taxpayer when declaring low income and the second part is the utility received by the taxpayer when reporting high-income.

The best response functions of high-income Complex and Simple taxpayers are:

$$
\hat{\alpha}_{C}(\beta)\left\{\begin{array} { l l } 
{ = 1 } & { \text { if } \beta < \beta _ { C } , } \\
{ \in [ 0 , 1 ] , } & { \text { if } \beta = \beta _ { C } , } \\
{ = 0 } & { \text { if } \beta > \beta _ { C } , }
\end{array} \quad \hat { \alpha } _ { S } ( \beta ) \left\{\begin{array}{ll}
=1 & \text { if } \beta<\beta_{S}, \\
\in[0,1], & \text { if } \beta=\beta_{S}, \\
=0 & \text { if } \beta>\beta_{S} .
\end{array}\right.\right.
$$

where,

$$
\beta_{C}=\frac{u\left(I_{H}-T_{L}\right)-u\left(I_{H}-T_{H}\right)}{\left[u\left(I_{H}-T_{L}\right)-u\left(I_{H}-T_{H}-F_{C}\right)\right] \gamma_{C}}, \quad \beta_{S}=\frac{u\left(I_{H}-T_{L}\right)-u\left(I_{H}-T_{H}\right)}{\left[u\left(I_{H}-T_{L}\right)-u\left(I_{H}-T_{H}-F_{S}\right)\right] \gamma_{S}}
$$

Note that $\beta_{C}$ and $\beta_{S}$ may be viewed as a threshold value of $\beta$ for Complex and Simple taxpayers, respectively. If $\beta$ is less than $\beta_{C}$, then the Complex taxpayers will evade with probability 1. If $\beta$ is equal to $\beta_{C}$, the Complex taxpayers will be indifferent. Finally, if $\beta$ is greater than $\beta_{C}$, then Complex taxpayers will evade with probability 0 . Analogous relations hold for $\beta$ and $\beta_{S}$.

The best response function of the IRS considers the strategies of both Complex $\left(\alpha_{C}\right)$ and Simple $\left(\alpha_{S}\right)$ taxpayers. It is given by

$$
\hat{\beta}\left(\alpha_{C}, \alpha_{S}\right)\left\{\begin{array}{ll}
=1 & \text { if } \mu\left(\alpha_{C}, \alpha_{S}\right)>\bar{\mu}, \\
\in[0,1], & \text { if } \mu\left(\alpha_{C}, \alpha_{S}\right)=\bar{\mu}, \\
=0 & \text { if } \mu\left(\alpha_{C}, \alpha_{S}\right)<\bar{\mu},
\end{array} \quad \text { where } \quad \bar{\mu}=\frac{c}{T_{H}+F-T_{L}}\right.
$$

Recall that $\mu=\mu\left(\alpha_{C}, \alpha_{S}\right)$ as defined in (2.1). Note that $\bar{\mu}$ may be viewed as a threshold value of $\mu$ for the IRS. If $\mu$ is less than $\bar{\mu}$, then the IRS does not audit. If $\mu$ is equal to $\bar{\mu}$, the IRS is indifferent. Finally, if $\mu$ is greater than $\bar{\mu}$, then the IRS audits with probability 1 .

In summary, the best response for the IRS is a strategy that maximizes its utility given the possible strategies of taxpayers. Likewise, the best response of Complex and Simple taxpayers 
are strategies that maximize their expected utility, given the strategy of the IRS. Finally, a Nash equilibrium is a vector $\left(\beta, \alpha_{C}, \alpha_{S}\right)$ of players' strategies that are best responses to one another. Consequently, in a Nash equilibrium, neither the IRS nor taxpayers (Complex and Simple) have an incentive to change their strategies, and as such it serves as a predictor of reality.

Following, we summarize the parameters and the strategies of this tax evasion game:

\section{Parameters}

$q$ - Proportion of of taxpayers with high income.

$\delta$ - Proportion of taxpayers (Complex) with higher reputation cost.

$c$ - Cost of audit for the IRS.

$R_{C}-$ Reputation cost for the Complex taxpayers.

$R_{S}$ - Reputation cost for the Simple taxpayers.

$F$ - Fine.

$T_{H}-$ Tax for high income.

$T_{L}-$ Tax for low income.

$I_{H}$ - High income level.

$I_{L}$ - Low income level.

$\gamma_{C}-$ Probability successful audit on Complex taxpayers.

$\gamma_{S}$ - Probability successful audit on Simple taxpayers.

\section{Strategies}

$\alpha_{C}$ - Probability of tax avoidance of Complex taxpayers.

$\alpha_{S}$ - Probability of tax avoidance of Simple taxpayers.

$\beta$ - Probability of audit.

In the next section, we present and analyze the equilibria of the game $G$. First, we assume there is no difference between the reputation costs of Complex and Simple taxpayers $\left(R_{C}=R_{S}\right)$. Then, analyze how the difference between these reputation costs affects the game's equilibria. This is particularity relevant since Complex taxpayers are larger and receive more attention from the IRS, society and the media. As will be seen, in equilibrium, the level of tax evasion of Complex taxpayers decreases discontinuously as its reputation costs increase. This may be one of the reasons why there is no statistical evidence to believe that Complex taxpayers evade more than Simple ones (See the part 3 of this the study). 


\subsection{Results}

First, we analyze the game results in the case where $q=0$ or $\bar{\mu}=1$. Let $r=T_{H}+F-T_{L}$ and recall that $\bar{\mu}=c / r$. If $q=0$. Then, all taxpayers have low income, and in any equilibrium, there is no tax avoidance and the IRS does not audit. On the other hand, if $\bar{\mu} \geq 1$, then the IRS also does not audit because the potential revenue $r$ per audit unit never compensates the unit cost $c$. In this case, all taxpayers with high income will evade in equilibrium.

We now consider the most interesting case, in which $q>0$ and $\bar{\mu}<1$. In this case, $q(1-\bar{\mu})>0$ and the best response function of the IRS, presented in (2.8), reduces to

$$
\hat{\beta}\left(\alpha_{C}, \alpha_{S}\right)\left\{\begin{array}{ll}
=1 & \text { if } \delta_{C} \alpha_{C}+\delta_{S} \alpha_{S}>b, \\
\in[0,1], & \text { if } \delta_{C} \alpha_{C}+\delta_{S} \alpha_{S}=b, \\
=0 & \text { if } \delta_{C} \alpha_{C}+\delta_{S} \alpha_{S}<b
\end{array} \quad \text { where } \quad b=\frac{(1-q) \bar{\mu}}{q(1-\bar{\mu})},\right.
$$

where $\delta_{C}=\gamma_{C} \delta$ and $\delta_{S}=\gamma_{S}(1-\delta)$.

We assume that

$$
\delta_{C}\left(=\gamma_{C} \delta\right)>0 \quad \text { and } \quad \delta_{S}\left(=\gamma_{S}(1-\delta)\right)>0
$$

Note that the above assumptions are reasonable insofar as we want to analyze the effect of a positive proportion of two groups of taxpayers $\delta>0$ where $1-\delta>0$. In addition, we assume that neither type of taxpayer has the power to escape from being successfully audited, that is, we assume that both $\gamma_{C}$ and $\gamma_{S}$ are positive, although one or the other is possibly very small, depending on the taxpayer's persuasiveness.

The parameter $b$, defined in (2.9), corresponds to the total cost divided by the total net gain for the IRS when it decides to audit all taxpayers that declare low income, and when all taxpayers who have high income declare low income. To see this fact, note that $b$ can be written as $b=[N(1-q)(r \bar{\mu})] /[N q(1-\bar{\mu}) r]=[N(1-q) c] /[N q(r-c)]$, where $N$ is the total number of taxpayers, $q$ is the proportion of high income taxpayers, and $r=T_{H}+F-T_{L}$ is the revenue received by the IRS when it successfully audits a high income taxpayer that declares low income.

It turns out that we can characterize the equilibria of the game $G$ in terms of the parameters $\delta_{C}, \delta_{S}, \beta_{C}, \beta_{S}$ and $b$, only. In order to present these characterizations, we use the fact that

$$
\beta_{C}>0 \text { and } \beta_{N}>0 \text {. }
$$

where $\beta_{C}$ and $\beta_{S}$ are defined in (2.7).

The inequalities in (2.11) result from (2.10) and the assumption that $T_{H}>T_{L}$ together with the fact that the taxpayers' utility of money $u$ is a strictly increasing function.

Lemma 1. Suppose that $b>\delta_{C}+\delta_{S}$. It follows that $\left(\beta, \alpha_{C}, \alpha_{S}\right)$ is an equilibrium if and only if

$$
\left(\beta, \alpha_{C}, \alpha_{S}\right)=(0,1,1) .
$$


Proof 1. If $\left(\beta, \alpha_{C}, \alpha_{S}\right)=(0,1,1)$, then $\delta_{C} \alpha_{C}+\delta_{S} \alpha_{S}=\delta_{C}+\delta_{S}<b$. In view of (2.9), we conclude that $\beta=0$ is the best response for the IRS. In contrast, since $\beta=0$ and (2.11) holds, we have that $\beta<\beta_{C}$ and $\beta<\beta_{S}$. Therefore, in view of (2.6), it follows that $\alpha_{C}=1$ and $\alpha_{S}=1$ are the best responses for taxpayers. From the above, it follows that $\left(\beta, \alpha_{C}, \alpha_{S}\right)$ is a Nash equilibrium of $G$.

Suppose now that $\left(\beta, \alpha_{C}, \alpha_{S}\right)$ is a Nash equilibrium of $G$. Since $b>\delta_{C}+\delta_{S} \geq \delta_{C} \alpha_{C}+$ $\delta_{S} \alpha_{S}$, it follows by (2.9) that $\beta=0$, and by (2.11, it follows that $\beta<\beta_{C}$ e $\beta<\beta_{S}$. From the last inequalities and (2.6), we conclude that $\alpha_{C}=1$ and $\alpha_{S}=1$.

Lemma 2. Suppose that $0 \leq b \leq \delta_{C}+\delta_{S}$. If $\left(\beta, \alpha_{C}, \alpha_{S}\right)$ is an equilibrium of $G$, then

$$
\delta_{C} \alpha_{C}+\delta_{S} \alpha_{S} \geq b
$$

Proof 2. Suppose, by way of contradiction, that $\delta_{C} \alpha_{C}+\delta_{S} \alpha_{S}<b$. Then, it follows, by (2.9), that the IRS does not audit. That is, $\beta=0$. But if the IRS does not audit, then all taxpayers evade in accordance with (2.6) and (2.11). That is $\alpha_{C}=\alpha_{S}=1$. As a consequence, $\delta_{C}+\delta_{S}=$ $\delta_{C} \alpha_{C}+\delta_{S} \alpha_{S}$, and hence, $\delta_{C}+\delta_{S}=\delta_{C} \alpha_{C}+\delta_{S} \alpha_{S}<b$. However, the latter inequality $\left(\delta_{C}+\delta_{S}<b\right)$ contradicts the hypothesis of the lemma, which requires that $b \leq \delta_{C}+\delta_{S}$.

Lemma 3. Supposes that $0<b=\delta_{C}+\delta_{S}$. Then $\left(\beta, \alpha_{C}, \alpha_{S}\right) \in[0,1]^{3}$ is an equilibrium of $G$ if and only if $\beta \leq \beta_{C}, \beta \leq \beta_{S}, \alpha_{C}=1$ e $\alpha_{S}=1$.

Proof 3. It is easy to see that any $\left(\beta, \alpha_{C}, \alpha_{S}\right) \in[0,1]^{3}$, where $\beta \leq \beta_{C}, \beta \leq \beta_{S}, \alpha_{C}=1$ and $\alpha_{S}=1$, is an equilibrium. In fact, since $\alpha_{C}=\alpha_{S}=1$ and $\delta_{C}+\delta_{S}=b$, then $\delta_{C} \alpha_{C}+\delta_{S} \alpha_{S}=$ $\delta_{C}+\delta_{S}=b$. Then it follows, by (2.9), that any $\beta$ is a best response for the IRS. On the other hand, since $\beta \leq \beta_{C}$ and $\beta \leq \beta_{S}$, it follows, by (2.6), that $\alpha_{C}=1$ and $\alpha_{S}=1$ are best responses to $\beta$, too.

Suppose $\left(\beta, \alpha_{C}, \alpha_{S}\right)$ is an equilibrium of $G$. We show first that $\alpha_{C}=1$ and $\alpha_{S}=1$. Suppose, by way of contradiction, that $\alpha_{C}<1$ or $\alpha_{S}<1$. In that case, $\delta_{C} \alpha_{C}+\delta_{S} \alpha_{S}<\delta_{C}+\delta_{S}=b$ and, by (2.9), the best response of the IRS is $\beta=0$. But if $\beta=0$, it follows, by (2.6) and (2.11), that the best responses of taxpayers are $\alpha_{C}=1$ and $\alpha_{S}=1$, in turn contradicting $\alpha_{C}<1$ or $\alpha_{S}<1$. Given that $\alpha_{C}=1$ and $\alpha_{S}=1$, we now show that $\beta \leq \beta_{C}$ and $\beta \leq \beta_{S}$. Suppose, by way of contradiction, that $\beta>\beta_{C}$ or $\beta>\beta_{S}$. In that case it follows, by (2.6), that $\alpha_{C}=0$ or $\alpha_{S}=0$, which contradicts the fact that $\alpha_{C}=1$ and $\alpha_{S}=1$.

Lemma 4. Suppose that $0 \leq b<\delta_{C}+\delta_{S}, \beta_{C}>1$ and $\beta_{S}>1$. Then $\left(\beta, \alpha_{C}, \alpha_{S}\right) \in[0,1]^{3}$ is an equilibrium of $G$ if and only if $\beta=\alpha_{C}=\alpha_{S}=1$.

Proof of Lemma 4. Since $\beta_{C}>1$ and $\beta_{S}>1$, it follows that that $\beta<\beta_{C}$ and $\beta<\beta_{S}$ for all values of $\beta \in[0,1]$. In view of (2.6), $\alpha_{C}$ and $\alpha_{S}$ are best responses to $\beta$ if and only if $\alpha_{C}=\alpha_{S}=1$. Now, if $\alpha_{C}=\alpha_{S}=1$, it follows that $\delta_{C} \alpha_{C}+\delta_{S} \alpha_{S}=\delta_{C}+\delta_{S}>b$, which, in view of (2.9), implies that $\beta$ is a best response to $\alpha_{C}$ and $\alpha_{S}$ if and only if $\beta=1$. 
For further characterization of the equilibria of $G$, we define:

$$
E=\text { Set of mixed Nash equilibria of } G
$$

Lemma 5. Suppose that $0 \leq b<\delta_{C}+\delta_{S}$, $\beta_{S}=1<\beta_{C}$. Then

$$
\left(\beta, \alpha_{C}, \alpha_{S}\right) \in E \quad \Leftrightarrow \quad \beta=1, \alpha_{C}=1 \text { and } \alpha_{S} \geq\left(b-\delta_{C}\right) / \delta_{S}
$$

In particular, if $b<\delta_{C}$, then $\left(\beta, \alpha_{C}, \alpha_{S}\right) \in E$ if and only if $\beta=1, \alpha_{C}=1$ and $\alpha_{S} \geq 0$.

Proof of Lemma 5. Taking into account the best response functions (2.6) and (2.9), it is immediately seen that the implication " $\Leftarrow$ " is satisfied. Next, we show the reverse implication “ $\Rightarrow$ ". Suppose that $\left(\beta, \alpha_{C}, \alpha_{S}\right)$ is an equilibrium of $G$. Since $\beta \leq 1<\beta_{C}$, we have, by (2.6), that $\alpha_{C}=1$. In addition, it follows by Lemma 2 that $\delta_{S}+\delta_{C} \alpha_{C}=\delta_{S} \alpha_{S}+\delta_{C} \alpha_{C} \geq b$, so $\alpha_{S} \geq\left(1-\delta_{C}\right) / \delta_{S}$. Now suppose, by way of contradiction, that $\beta<1$. In that case, we would have that $\beta<\beta_{S}=1<\beta_{C}$, and as a consequence of (2.6), that $\alpha_{S}=\alpha_{C}=1$. Using the hypothesis of the lemma, it follows that $\delta_{S} \alpha_{S}+\delta_{C} \alpha_{C}=\delta_{S}+\delta_{C}>b$. Now, in view of the best response function of the IRS (2.9), it follows that $\beta=1$, which contradicts the supposition that $\beta<1$.

Proposition 1. Suppose that $0<b<\delta_{C}+\delta_{S}, \quad \beta_{S}<1$, and $\beta_{S}<\beta_{C}$.

$$
\begin{aligned}
& \text { If } \delta_{C}<b \text {, then } \\
& \qquad\left(\beta, \alpha_{C}, \alpha_{S}\right) \in E \Leftrightarrow \beta=\beta_{S}, \alpha_{C}=1 \text {, and } \alpha_{S}=\left(b-\delta_{C}\right) / \delta_{S} . \\
& \text { If } \delta_{C}=b \text {, then }
\end{aligned}
$$

$$
\left(\beta, \alpha_{C}, \alpha_{S}\right) \in E \quad \Leftrightarrow \quad \beta_{S} \leq \beta \leq \beta_{C}, \alpha_{C}=1 \text {, and } \alpha_{S}=0 .
$$

To prove Proposition 1 and other results, use the following lemma.

Lemma 6. Suppose that $\left(\beta, \alpha_{C}, \alpha_{S}\right)$ is an equilibrium of $G$, where $\beta_{S} \leq 1$ and $\beta_{S} \leq \beta_{C}$. If $0 \leq b<\delta_{C}+\delta_{S}$, then $\beta_{S} \leq \beta$. If $0<b<\delta_{C}+\delta_{S}$, then $\beta_{S} \leq \beta \leq \beta_{C}$.

Proof of Lemma 6. First we show that $\beta_{S} \leq \beta$. Suppose, by way of contradiction, that $\beta<\beta_{S}$. Since $\beta_{S} \leq 1$, we have that $\beta<1$, and since $\left(\beta, \alpha_{C}, \alpha_{S}\right)$ is an equilibrium of $G$, it follows, by (2.9), that $\delta_{C} \alpha_{C}+\delta_{S} \alpha_{S} \leq b$. Taking into account Lemma 2, we conclude that $\delta_{C} \alpha_{C}+\delta_{S} \alpha_{S}=b$. Furthermore, under the assumption that $\beta<\beta_{S}$, we have $\beta<\beta_{S} \leq \beta_{C}$ and therefore $\alpha_{S}=$ $\alpha_{C}=1$. Since $b=\delta_{C} \alpha_{C}+\delta_{S} \alpha_{S}$ and $\alpha_{S}=\alpha_{C}=1$, it follows that $b=\delta_{S} \alpha_{S}+\delta_{C} \alpha_{C}=\delta_{S}+\delta_{C}$. But the latter equality contradicts the hypothesis of the Lemma that requires that $b<\delta_{S}+\delta_{C}$.

Now suppose that $b>0$. We next show that $\beta \leq \beta_{C}$. Suppose, by way of contradiction, that $\beta>\beta_{C}$. Since $\beta_{C} \geq \beta_{S}$, it follows, by (2.6), that $\alpha_{S}=\alpha_{C}=0$ and so $\delta_{S} \alpha_{S}+\delta_{C} \alpha_{C}=0$. Therefore, by Lemma 2, we have $0=\delta_{S} \alpha_{S}+\delta_{C} \alpha_{C} \geq b$, which contradicts the hypothesis that $b>0$. 
Proof of Proposition 1. Taking into account the best response functions (2.6) and (2.9), one can immediately see that the implications " $\Leftarrow$ " in equivalences (2.16) and (2.17) are satisfied. Next, we show the reverse implications " $\Rightarrow$ ". Suppose that $\left(\beta, \alpha_{C}, \alpha_{S}\right)$ is an equilibrium of $G$. Then, if $\delta_{C}<b$, the condition on the right-hand side of (2.16) holds, and if $\delta_{C}=b$, then the condition on the right-hand side of (2.17) holds. The proof is presented in the following steps.

1. If $\delta_{C}<b$, then $\beta=\beta_{S}$ and $\alpha_{C}=1$.

Proof. By Lemma 6, we have that $\beta \geq \beta_{S}$. To show that $\beta=\beta_{S}$, it is sufficient to show that that $\beta \leq \beta_{S}$. Suppose, by way of contradiction, that $\beta>\beta_{S}$. Then $\alpha_{S}=0$ and therefore, by Lemma 2, we conclude that $b \leq \delta_{S} \alpha_{S}+\delta_{C} \alpha_{C}=\delta_{C} \alpha_{C} \leq \delta_{C}$. However, the previous inequality contradicts the hypothesis that $b>\delta_{C}$. Since $\beta=\beta_{S}<\beta_{C}$, it holds also that $\alpha_{C}=1$.

2. If $\delta_{C}=b$, then $\alpha_{S}=0, \alpha_{C}=1$ and $\beta_{S} \leq \beta \leq \beta_{C}$.

Proof. Taking into account the best response functions of the taxpayers (2.6), it is sufficient to show that $\alpha_{S}=0$, and $\alpha_{C}=1$. We show this in two cases $\left(\beta>\beta_{S}\right.$ and $\left.\beta \leq \beta_{S}\right)$. Suppose first that $\beta>\beta_{S}$. Then it follows, by (2.6), that $\alpha_{S}=0$ and, by Lemma 2, it follows that $\delta_{C} \alpha_{C}=\delta_{C} \alpha_{C}+\delta_{S} \alpha_{S} \geq b=\delta_{C}$. Since $\delta_{C} \alpha_{C} \geq \delta_{C}$ and $\delta_{C}>0$, it follows that $\alpha_{C} \geq 1$, that is, $\alpha_{C}=1$. Now suppose that $\beta \leq \beta_{S}$. Then we have that $\beta \leq \beta_{S}<\beta_{C}$, which, by (2.6), implies that $\alpha_{C}=1$. Since $\beta_{S}<1$, it follows also that $\beta<1$. Taking into account the best response function of the IRS (2.9), it follows that $\delta_{C} \alpha_{C}+\delta_{S} \alpha_{S} \leq b$. Since $\alpha_{C}=1$, we conclude that $\delta_{C}+\delta_{S} \alpha_{S} \leq b=\delta_{C}$, which implies that $\delta_{S} \alpha_{S} \leq 0$. Since $\delta_{S}>0$ and $\alpha_{S} \geq 0$, we conclude that $\alpha_{S}=0$.

3. It holds that $\alpha_{S}=\left(b-\delta_{C}\right) / \delta_{S}$.

Proof. By Items 1 and 2, we know that $\alpha_{C}=1$. Therefore, it is sufficient to show that $\delta_{C} \alpha_{C}+\delta_{S} \alpha_{S}=b$. In view of Lemma 2 , it is sufficient to show that $\delta_{C} \alpha_{C}+\delta_{S} \alpha_{S} \leq b$. We show that $\delta_{C} \alpha_{C}+\delta_{S} \alpha_{S} \leq b$ in two cases $\left(\delta_{C}<b\right.$ and $\left.\delta_{C}=b\right)$.

Suppose first that $\delta_{C}<b$. Then it follows, by Item 1 , that $\beta=\beta_{S}<1$ and therefore $\beta<1$. Using the best response function of the IRS (2.9), we conclude that $\delta_{C} \alpha_{C}+\delta_{S} \alpha_{S} \leq b$. Suppose now that $\delta_{C}=b$. Then it follows, by Item 2 , that $\alpha_{S}=0$ and $\alpha_{C}=1$. Therefore, $\delta_{C} \alpha_{C}+\delta_{S} \alpha_{S}=\delta_{C} \leq b$.

Now, note that the right-hand side of (2.16) follows immediately from Items 1 and 3, while the right-hand side of (2.17) follows immediately from Item 2.

Lemma 7. Suppose that $\beta_{S}<1, \beta_{S}<\beta_{C}$ and $0 \leq b<\delta_{C}$. If $\left(\beta, \alpha_{C}, \alpha_{S}\right)$ is an equilibrium of $G$, then $\alpha_{S}=0$.

Proof. Suppose, by way of contradiction, that $\alpha_{S}>0$. Then, by (2.6), it follows that $\beta \leq \beta_{S}<\beta_{C}$, where $\beta_{S}<1$. Therefore, $\beta<\beta_{C}$ and $\beta<1$. As a consequence, it follows, by (2.6) and (2.9), 
that $\alpha_{C}=1$ and $\delta_{C} \alpha_{C}+\delta_{S} \alpha_{S} \leq b$, respectively. From the two previous assertions we conclude that $\delta_{C} \leq \delta_{C}+\delta_{S} \alpha_{S}=\delta_{S} \alpha_{S}+\delta_{C} \alpha_{C} \leq b$, which implies that $\delta_{C} \leq b$. But the previous inequality contradicts the hypothesis that $\delta_{C}>b$.

Proposition 2. Suppose that $\beta_{S}<1, \beta_{S}<\beta_{C}$ and $0 \leq b<\delta_{C}$.

If $\beta_{S}<1<\beta_{C}$, then

$$
\left(\beta, \alpha_{C}, \alpha_{S}\right) \in E \quad \Leftrightarrow \quad \beta=1, \alpha_{C}=1, \text { and } \alpha_{S}=0
$$

If $\beta_{N}<1=\beta_{I}$, then

$$
\left(\beta, \alpha_{I}, \alpha_{N}\right) \in E \quad \Leftrightarrow \quad \beta=1, \alpha_{I} \geq b / \delta_{I}, \text { and } \alpha_{N}=0
$$

If $\beta_{S}<\beta_{C}<1$ and $0<b$, then

$$
\left(\beta, \alpha_{C}, \alpha_{S}\right) \in E \quad \Leftrightarrow \quad \beta=\beta_{C}, \alpha_{C}=b / \delta_{C}, \text { and } \alpha_{S}=0
$$

If $\beta_{S}<\beta_{C}<1$ and $0=b$, then

$$
\left(\beta, \alpha_{C}, \alpha_{S}\right) \in E \quad \Leftrightarrow \quad \beta \geq \beta_{C}, \alpha_{C}=b / \delta_{C}=0 \text { and } \alpha_{S}=0 .
$$

Proof of Proposition 2. Taking into account the best response functions (2.6) and (2.9), it can be immediately noted that the implications " $\Leftarrow$ " in equivalences (2.18)-(2.21) are satisfied. Next, we show the reverse implications " $\Rightarrow$ ". Suppose that $\left(\beta, \alpha_{C}, \alpha_{S}\right)$ is an equilibrium of $G$. We show that if the preconditions of Equivalences (2.18)-(2.21) so are satisfied, are their respective right-hand sides. The proof is presented in the following steps.

1. If $\beta_{S}<1<\beta_{C}$, then

$$
\left(\beta, \alpha_{C}, \alpha_{S}\right) \in E \quad \Rightarrow \quad \beta=1, \alpha_{C}=1 \text { and } \alpha_{S}=0 .
$$

Proof. Since $\beta \leq 1<\beta_{C}$, it follows, by (2.6), that $\alpha_{C}=1$. Suppose, by way of contradiction, that $\beta<1$. Then it follows, by (2.9), that $\delta_{C} \alpha_{C}+\delta_{S} \alpha_{S} \leq b$, and therefore, $\delta_{C} \leq \delta_{C}+\delta_{S} \alpha_{S}=\delta_{C} \alpha_{C}+\delta_{S} \alpha_{S} \leq b$, which in turn contradicts $b<\delta_{C}$. Therefore, $\beta=1$. Since $\beta=1>\beta_{S}$, it follows, by (2.6), that $\alpha_{S}=0$.

2. If $\beta_{S}<1=\beta_{C}$, then

$$
\left(\beta, \alpha_{C}, \alpha_{S}\right) \in E \Rightarrow \beta=1, \alpha_{C} \geq b / \delta_{C} \text { and } \alpha_{S}=0
$$

Proof. Suppose, by way of contradiction, that $\beta<1$. Then it follows, by (2.9), that $\delta_{C} \alpha_{C}+\delta_{S} \alpha_{S} \leq b$. In addition, $\beta<1=\beta_{C}$, which by (2.6) yields $\alpha_{C}=1$. As a consequence, $\delta_{C} \leq \delta_{C}+\delta_{S} \alpha_{S}=\delta_{C} \alpha_{C}+\delta_{S} \alpha_{S} \leq b$, which in turn contradicts $b<\delta_{C}$. 
Therefore, it must hold that $\beta=1$. Now, suppose, by way of contradiction, that $\alpha_{S}>0$. Then it follows, by (2.6), that $\beta \leq \beta_{S}<1$, which contradicts $\beta=1$. Therefore, it must hold that $\alpha_{S}=0$. Finally, applying Lemma 2, we conclude that $\delta_{C} \alpha_{C}=\delta_{C} \alpha_{C}+\delta_{S} \alpha_{S} \geq b$, and hence, $\alpha_{C} \geq b / \delta_{C}$.

3. If $\beta_{S}<\beta_{C}<1$ and $0<b$, then

$$
\left(\beta, \alpha_{C}, \alpha_{S}\right) \in E \Rightarrow \beta=\beta_{C}, \alpha_{C}=b / \delta_{C} \text { and } \alpha_{S}=0
$$

Proof. First we show that $\beta=\beta_{C}$. Since $b>0$, it follows, by Lemma 6 , that $\beta \leq \beta_{C}$. Next we show that $\beta \geq \beta_{C}$. Suppose, by way of contradiction, that $\beta<\beta_{C}$. Then it follows, by (2.6), that $\alpha_{C}=1$. Since $\beta_{C}<1$, it follows also that $\beta<\beta_{C}<1$. Since $\beta<1$, it follows, by (2.9), that $\delta_{C} \alpha_{C}+\delta_{S} \alpha_{S} \leq b$. Finally, since, $\alpha_{C}=1$, it follows that $\delta_{C} \leq \delta_{C}+\delta_{S} \alpha_{S}=\delta_{C} \alpha_{C}+\delta_{S} \alpha_{S} \leq b$, which contradicts the hypothesis of the proposition which requires that $\delta_{C}>b$. Therefore, it must hold that $\beta=\beta_{C}$. Now, since $\beta=\beta_{C}>\beta_{S}$, it follows, by (2.6), that $\alpha_{S}=0$. Finally, by Lemma 2, we conclude that $\delta_{C} \alpha_{C}=\delta_{C} \alpha_{C}+\delta_{S} \alpha_{S} \geq b$, and therefore $\alpha_{C} \geq b / \alpha_{C}$.

4. If $\beta_{S}<\beta_{C}<1$ and $0=b$, then

$$
\left(\beta, \alpha_{C}, \alpha_{S}\right) \in E \Rightarrow \beta \geq \beta_{C}, \alpha_{C}=b / \delta_{C}=0 \text { and } \alpha_{S}=0
$$

Proof. Suppose, by way of contradiction, that $\alpha_{C}>0$ or $\alpha_{S}>0$. Since $\delta_{C}>0$ and $\delta_{S}>0$, it follows that $\delta_{C} \alpha_{C}+\delta_{S} \alpha_{S}>0=b$. By (2.9), it follows that $\beta=1$, and since $1>\beta_{C}>\beta_{S}$, we have that $\beta>\beta_{C}>\beta_{S}$. Now, in view of (2.6), we further conclude that $\alpha_{C}=0$ and $\alpha_{S}=0$, which contradicts the assumption that $\delta_{C}>0$ and $\delta_{S}>0$. Therefore, it must hold that $\alpha_{C}=0$ and $\alpha_{S}=0$. Finally, since $\alpha_{C}=0$, it follows, by (2.6), that $\beta \geq \beta_{C}$.

Now note that the right-hand sides of (2.18)-(2.21) follow immediately from Items 1, 2, 3, and 4, respectively.

Proposition 3. Suppose that $0 \leq b<\delta_{C}+\delta_{S}$ and $\beta_{S}=\beta_{C}$.

1. If $\beta_{S}=\beta_{C}=1$, then

$$
\left(\beta, \alpha_{C}, \alpha_{S}\right) \in E \Leftrightarrow \beta=\beta_{S}=\beta_{C} \text { and } \delta_{C} \alpha_{C}+\delta_{S} \alpha_{S} \geq b \text {. }
$$

2. If $0<\beta_{S}=\beta_{C}<1$ and $0<b$, then

$$
\left(\beta, \alpha_{C}, \alpha_{S}\right) \in E \Leftrightarrow \beta=\beta_{S}=\beta_{C} \text { and } \delta_{C} \alpha_{C}+\delta_{S} \alpha_{S}=b \text {. }
$$


3. If $0<\beta_{S}=\beta_{C}<1$ and $0=b$, then

$$
\left(\beta, \alpha_{C}, \alpha_{S}\right) \in E \quad \Leftrightarrow \quad \beta \geq \beta_{S}=\beta_{C} \text { and } \delta_{C} \alpha_{C}+\delta_{S} \alpha_{S}=b .
$$

Proof of Proposition 3. Taking into account the best response functions (2.6) and (2.9), it can immediately be noted that the implications " $\Leftarrow$ " in equivalences (2.22), (2.23), and (2.24) are satisfied. Next, we show the reverse implications " $\Rightarrow$ ". Suppose that $\left(\beta, \alpha_{C}, \alpha_{S}\right)$ is an equilibrium of $G$. If the preconditions of Equivalences (2.22), (2.23), and (2.24) are satisfied, so are their respective right-hand sides. The proof is presented in the following steps.

1. If $\beta_{S}=\beta_{C}=1$, then $\beta=\beta_{S}=\beta_{C}$ and $\delta_{C} \alpha_{C}+\delta_{S} \alpha_{S} \geq b$.

Proof. By Lemma 2, it is sufficient to show that $\beta=\beta_{S}=\beta_{C}$. Suppose, by way of contradiction, that the last equality does not hold. Since $\beta_{S}=\beta_{C}=1$, it follows that $\beta<1=\beta_{S}=\beta_{C}$, and by (2.6), we conclude that $\alpha_{C}=\alpha_{S}=1$. Since $\beta<1$, it follows, by (2.9), that $\delta_{C} \alpha_{C}+\delta_{S} \alpha_{S} \leq b$. Taking into account that $\alpha_{C}=\alpha_{S}=1$, we conclude that $\delta_{C}+\delta_{S}=\delta_{C} \alpha_{C}+\delta_{S} \alpha_{S} \leq b$, which contradicts the hypothesis that $b<\delta_{C}+\delta_{S}$.

2. If $0<\beta_{S}=\beta_{C}<1$ and $0<b$, then $\beta_{S} \leq \beta \leq \beta_{C}$ and $\delta_{C} \alpha_{C}+\delta_{S} \alpha_{S}=b$.

Proof. By Lemma 6, we have that $\beta_{S} \leq \beta \leq \beta_{C}$. It remains to show that $\delta_{C} \alpha_{C}+\delta_{S} \alpha_{S}=b$. Suppose, by way of contradiction, that $\delta_{C} \alpha_{C}+\delta_{S} \alpha_{S}<b$ or $\delta_{C} \alpha_{C}+\delta_{S} \alpha_{S}>b$. In the first case, it follows, by (2.9), that $\beta=0$, and in the second case, it follows, also by (2.9), that $\beta=1$. However, in either of these two cases, there is contradiction of $0<\beta_{S} \leq \beta \leq \beta_{C}<1$.

3. If $0<\beta_{S}=\beta_{C}<1$ and $0=b$, then $\beta \geq \beta_{S}=\beta_{C}$ and $\delta_{C} \alpha_{C}+\delta_{S} \alpha_{S}=b$.

Proof. By Lemma 6, we have that $\beta \geq \beta_{S}=\beta_{C}$. It remains to show that $\delta_{C} \alpha_{C}+\delta_{S} \alpha_{S}=b$. By Lemma 2, $\delta_{C} \alpha_{C}+\delta_{S} \alpha_{S} \geq b$. Suppose, by way of contradiction, that $\delta_{C} \alpha_{C}+\delta_{S} \alpha_{S}>b$. Then, it follows, by (2.9), that $\beta=1>\beta_{S}=\beta_{C}$. Then, by (2.6), it follows that $\alpha_{S}=$ $\alpha_{C}=0$ and $\delta_{C} \alpha_{C}+\delta_{S} \alpha_{S}=0=b$, contradicting the assumption that $\delta_{C} \alpha_{C}+\delta_{S} \alpha_{S}>b$.

Now note that the right-hand sides of (2.22), (2.23) and (2.24) follow immediately from Items 1, 2 , and 3 , respectively.

\subsection{Comparative statics}

Let $\alpha_{*}(F)$ be the fraction of high-income taxpayers that evade in equilibrium of $G$ among all high-income taxpayers, respectively. Since low-income taxpayers do not evade, $\alpha_{*}(F)$ is proportional to the overall fraction of taxpayers that evade in equilibrium, which is $q \times \alpha_{*}(F)$. In the previous notation, we stressed the dependence of $\alpha_{*}(F)$ on fine $F$, although $\alpha_{*}(F)$ also depends on the other model parameters, which are initially meant to be fixed but arbitrary. 
Next we show that $\alpha_{*}(F)$ has at most one discontinuity point, hereafter denoted by $F_{*}$, if it exists. In addition, we show that if the reputation cost $R_{C}$ is sufficiently large, then $\alpha_{*}(F)$ is discontinuous (at $F_{*}$ ), and more relevantly, $\alpha_{*}(F)$ is non-monotonic around $F_{*}$, no matter how $\alpha_{*}(F)$ is defined in the case when the game $g$ has multiple equilibria.

The non-monotonicity of $F \rightarrow \alpha_{*}(F)$ is not intuitive and has important consequences. In particular, it shows that the total fraction of tax-evaders may even increase when the fine $F$ increases. To prove these results, we will assume that the utility function for money is the identity function, that is, $u(x)=x$ of all $x \in \mathbb{R}$. Although this assumption is not necessary, it facilitates the arguments that support our findings.

Let $\alpha_{*}^{+}:[0, \infty) \rightarrow[0,1]$ and $\alpha_{*}^{-}:[0, \infty) \rightarrow[0,1]$ be two functions defined as follows:

$\alpha_{*}^{+}(b)=\left\{\begin{array}{ll}\frac{b}{\gamma_{C}} & \text { if } b \in\left[0, \delta_{C}\right), \\ \frac{b}{\gamma_{S}}+\frac{\left(\gamma_{S}-\gamma_{C}\right) \delta}{\gamma_{S}} & \text { if } b \in\left[\delta_{C}, \delta_{C}+\delta_{S}\right), \\ 1 & \text { if } b \in\left[\delta_{C}+\delta_{S}, \infty\right),\end{array} \quad \alpha_{*}^{-}(b)= \begin{cases}\frac{b}{\gamma_{S}} & \text { if } b \in\left[0, \delta_{S}\right), \\ \frac{b}{\gamma_{C}}+\frac{\left(\gamma_{C}-\gamma_{S}\right) \delta}{\gamma_{C}} & \text { if } b \in\left[\delta_{S}, \delta_{C}+\delta_{S}\right), \\ 1 & \text { if } b \in\left[\delta_{C}+\delta_{S}, \infty\right),\end{cases}\right.$

where $\delta_{C}=\gamma_{C} \delta$ and $\delta_{S}=\gamma_{S}(1-\delta)$. Further, we set

$$
F_{*}=\frac{\gamma_{C} R_{C}-\gamma_{S} R_{S}}{\gamma_{S}-\gamma_{C}}-\left(T_{H}-T_{L}\right) .
$$

Now, denote by $\mathrm{A}_{*}$ the set of fractions of high-income tax evaders in an equilibrium of $G$.

Lemma 8. Let $b(F)=[(1-q) c] /\left[q\left(T_{H}-T_{L}\right)+F-c\right]$. If $F=F_{*}$, then

$$
\alpha \in \mathrm{A}_{*} \quad \Leftrightarrow \quad \alpha_{*}^{-}\left(b\left(F_{*}\right)\right) \leq \alpha \leq \alpha_{*}^{+}\left(b\left(F_{*}\right)\right) .
$$

Moreover, if $F \neq F_{*}$, then $\mathrm{A}_{*}$ has a unique element, given by

$$
\alpha_{*}(F)= \begin{cases}\alpha_{*}^{+}(b(F)) & \text { if } F<F_{*}, \\ \alpha_{*}^{-}(b(F)) & \text { if } F>F_{*} .\end{cases}
$$

Proof of Lemma 8. Equations (2.29) and (2.28) follow straightforwardly from the characterization of the Nash equilibria $\left(\beta, \alpha_{C}, \alpha_{C}\right)$ of $G$ presented in the previous section, taking into account that $\alpha_{*}(F)=\delta \alpha_{C}+(1-\delta) \alpha_{S}$.

The functions $\alpha_{*}^{-}(b)$ and $\alpha_{*}^{+}(b)$, defined as in (2.25), are continuous. In addition, both functions are strictly increasing in the interval $\left[0, \delta_{C}+\delta_{S}\right] \alpha_{*}^{-}(b)<\alpha_{*}^{+}(b)$ for $b \in\left(0, \delta_{C}+\delta_{S}\right)$; 
and both functions equal 1 for $b \in\left[\delta_{C}+\delta_{S}, \infty\right)$. As a consequence, if the reputation cost $R_{C}$ is sufficiently large, then $b\left(F_{*}\right) \in\left(0, \delta_{C}+\delta_{S}\right)$, and $\alpha_{*}(F)$ is discontinuous at $F_{*}$. Since $b(F)=[(1-q) c] /\left[q\left(T_{H}-T_{L}\right)+F-c\right]$, it follows that $b(F)$ is decreasing in $F$, and so

$$
\lim _{F \rightarrow F_{*}^{-}} \alpha_{*}(F)=\alpha_{*}^{-}\left(b\left(F_{*}\right)\right)<\alpha_{*}^{+}\left(b\left(F_{*}\right)\right)=\lim _{F \rightarrow F_{*}^{+}} \alpha_{*}(F) .
$$

In particular, there are fines $F_{1}<F_{2}$ such that $\alpha_{*}\left(F_{C}\right)<\alpha_{*}\left(F_{2}\right)$. Although the nonmonotonicity of $\alpha_{*}(F)$ holds around the discontinuity point $F_{*}$, the function $\alpha_{*}(F)$ is continuous and monotonic in the intervals $\left[0, F_{*}\right)$ and $\left(F_{*}, \infty\right)$, separately. See Figure 2.1.

Lemma 8 states that a policymaker should be careful when dealing with Complex taxpayers, or more specifically, when taxpayer groups have strong influence and reputation costs point in the opposite direction. In particular, a policymaker should not increase a fine in any case to mitigate tax-evasion. As will be seen (from Lemma 9), a more advisable policy is to increase the fine and reputation cost simultaneously such that the discontinuity point $F_{*}$ (as a function of the reputation costs) increases as fine $F$ approaches $F_{*}$. In order to increase evaders' reputation costs, a policymaker can make tax evasion more transparent, such that it has a greater negative impact on the evader's stock price.

To be specific, suppose that:

$$
R_{C}=r_{C} P \text { and } R_{S}=r_{S} P\left(r_{C}>r_{S}\right)
$$

where $P>0$ stands for the level of publicity of tax-evasion provided by a policymaker.

Suppose that an Complex taxpayer's reputation costs is more sensitive to the publicity of tax evasion such that $r_{C}>\left(\gamma_{S} / \gamma_{C}\right) r_{S}$. In view of (2.30), Equation (2.26) reduces to

$$
F_{*}=F_{*}(P)=\frac{\gamma_{C} r_{C}-\gamma_{S} r_{S}}{\gamma_{S}-\gamma_{C}} P-\left(T_{H}-T_{L}\right)
$$

Then the following lemma operates:

Lemma 9. The function $F_{*}(P)$ is increasing in $P$. In addition, $F_{*}(P)$ does not depend on $F$ and $\alpha_{*}^{+}(b(F))$ and $\alpha_{*}^{-}(b(F))$ do not depend on $P$.

Proof of Lemma 9. The monotonicity of $F_{*}(P)$ and the fact that $F_{*}(P)$ does not depend on $F$ follows immediately from the definition of $F_{*}(P)$ as in (2.31) and the inequality $r_{I}>\left(\gamma_{S} / \gamma_{C}\right) r_{S}$. The fact that $\alpha_{*}^{+}(b(F))$ and $\alpha_{*}^{-}(b(F))$ do not depend on $P$ follows from the definitions of the functions $\alpha_{*}^{+}$and $\alpha_{*}^{-}$, presented in (2.25), and the definition of $b(F)$, which is given by

$$
b(F)=\frac{(1-q) c}{q\left[\left(T_{H}-T_{L}\right)-c\right]+q F}
$$


According to Lemma 9, it is possible to combine an increase $\Delta F$ of $F$ with an increase $\Delta P$ of $P$ (such that $\Delta P=\xi \Delta F$ for a certain constant $\xi>0)$ such that $\Delta \alpha_{*}:=\alpha_{*}(F+\Delta F, P+$ $\Delta P)-\alpha_{*}(F, P)$ is nonnegative. ${ }^{7}$ There are two advantages in doing so. First, the variation of the tax evasion $\Delta \alpha_{*}$ is never negative, no matter how small $\Delta F$ and $\Delta P$ are. Moreover, it is certainly positive if $F$ is sufficiently large. In contrast, if only $F$ increases (and $P$ remains constant), then the resulting increment $\Delta \alpha_{*}$ may be even negative, as shown in Lemma 8. Second, if $F$ is close to the discontinuity point $F_{*}(P)$ and if $F<F_{*}(P)$, then a very small increase of $P$ (even when it is coupled with an increase of $F$ ) leads to a discontinuous decrease of $\alpha_{*}(F, P)$. This gives a good opportunity to decrease tax evasion substantially at negligible costs (whenever the government incurs political costs to increase $F$ or $P$ ).

In the next section, we summarize and illustrate the results so far.

\subsubsection{Illustration of the results}

The aim of this section is to illustrate and summarize the results from the equilibria (2.4) and the results obtained from the comparative statics (2.5). Figure 2.1 summarizes these results. In this figure the orange line represents Complex taxpayers (Banks) and the green line represents Simple taxpayers (Non-banks).

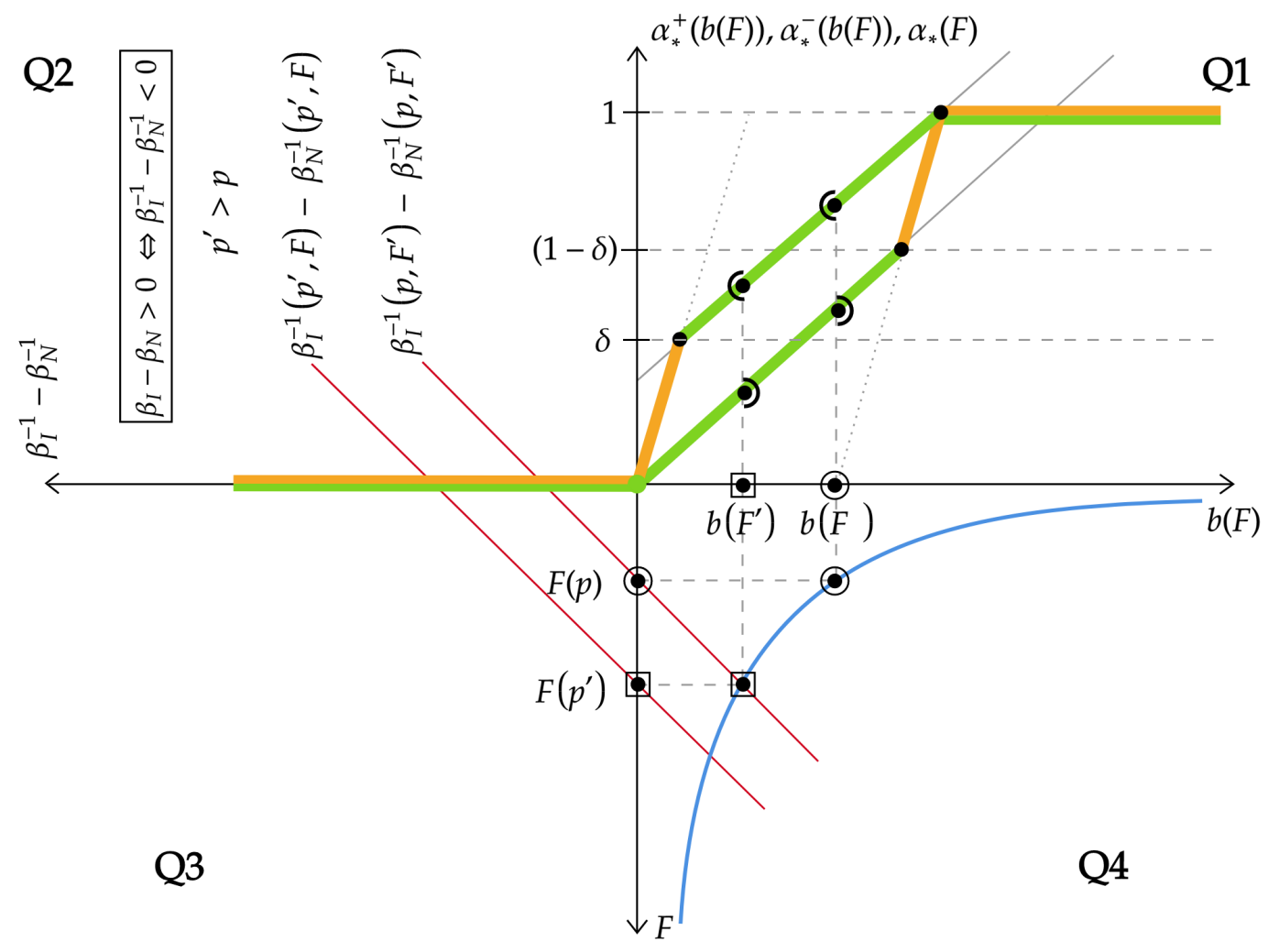

Figure 2.1 - Summary of the results

$7 \quad$ In the previous notation, we stress the dependence of the total fraction of tax evaders $\alpha_{*}(F, P)$ on both the fine $F$ and the Publicity level of tax evasion $P$. 
Our theoretical model based on game theory models the dilemma of powerful taxpayers. The results show that reputation affects discontinuously the taxpayers' behavior. When reputation costs increase, there comes a moment when this cost goes beyond the threshold which involves their persuasion power of affecting the probability of success of the IRS audit. Therefore, the reputation risk becomes mandatory and these taxpayers will no longer evade taxes because reputation is the determining factor in this dilemma. The Complex taxpayers are powerful. However, they need to pay attention to reputation cost. In our model, we demonstrate to what extent they should pay attention to this cost.

Moreover, we find that if the reputation risk is greater than the threshold reputation risk, these taxpayers will not evade and only the other taxpayers will evade. We also find that the reputation risk depends on the fine, negatively or positively. This shows that increasing the fine can increase the evasion level of the more powerful taxpayers (Complex taxpayers) because they affect the likelihood of being detected when evading taxes. In other words, increasing the fine has an opposite effect for these taxpayers. Interestingly, the Complex taxpayers will benefit from the increase of the fine. This happens because this type of taxpayer can affect the probability of audit success. This result is counterintuitive!

However, there is reputation cost threshold. Thus, if the reputation cost is above this threshold, these taxpayers will begin to evade less. In contrast, if it is below, they will evade more. We find that the threshold is a function of the fine and it grows when the fine rises. Therefore, if the threshold grows, these taxpayers have more incentive to evade taxes. Curiously, increasing the fine changes the behavior of the Complex taxpayers since they begin to engage in more tax avoidance. In other words, as the fine increases, the Complex taxpayers (Banks) become more aggressive when practicing tax avoidance.

On the other hand, Complex taxpayers have higher reputation cost due to their size. As mentioned, large firms receive more attention from society, the IRS and the media. Thus, this cost restrains them from being aggressive when practicing tax avoidance. Therefore, it is very important to increase their reputation cost. A way to do this is to increase the disclosure of tax avoidance cases. Interestingly, increasing the fine serves to increase tax evasion as a whole. The solution is to increase the reputation cost and the fine simultaneously. In this way, the number of evaders will decrease, creating a huge gain for the IRS.

In summary, our results show: a) how Complex taxpayers (Banks) benefit when the fine increases; b) What the threshold fine is, above which all taxpayers begin to evade; c) how banks are sensitive to reputation cost; d) how the IRS can decrease tax avoidance; and e) how increasing disclosure of tax avoidance cases can restrain banks from being aggressive when practicing tax avoidance. 


\subsection{Conclusion}

Many countries around the world have problems with tax avoidance. This problem has puzzled both government officials and academics. In recent decades, many studies have been published. However, both the causes and the appropriate responses to this problem remain controversial. One the reasons for this is that the previous models are broad and also do not consider reputation cost.

Therefore, in this part we propose a theoretical model based on game theory that analyzes the interplay among the IRS, Banks and Non-banks. In this game, the IRS faces two types of taxpayers: Complex (Banks) and Simple (Non-banks). We divided the analysis into two moments. In the first moment, we consider that the reputation costs are similar for Complex and Simple taxpayers. In this case, we find that in equilibrium, Banks are the leading evaders. They are more aggressive when practicing tax avoidance than Non-banks. As the cost-benefit ratio of auditing increases, the number of taxpayers that evade in equilibrium also increases. Thus, there comes a moment when the Simple taxpayers will also evade. This result is aligned with the literature that does not consider the reputation cost. Therefore, banks are expected to be more aggressive than other companies when practicing tax avoidance.

However, many studies have shown that because Banks are large, they receive more attention from the IRS, society and the media. Consequently, they have higher reputation costs. Therefore, in the second moment, we consider that Banks have higher reputation costs. Thus, the result changes and we find that in equilibrium, Simple taxpayers (Non-banks) are more aggressive than Complex ones (Banks). This happens because practicing tax avoidance is more costly for Banks than for Non-banks. In the final result, we find that an equilibrium exists in which the proportion of taxpayers evading will be composed of both by Simple and Complex taxpayers. We conclude that the only parameters that affect the Nash equilibrium are: the cost-benefit ratio of auditing, the probability of success of the audit and reputation costs.

By calculating the comparative statics we find that Complex taxpayers (Banks) benefit when the fine increases. This occurs because they can affect the probability of IRS inspections. We demonstrate there is a threshold fine. This result is aligned with Laffer's theorem. Thus, if the fine is above this threshold, all taxpayers will evade. However, Complex taxpayers are sensitive to reputation costs, restraining them from engaging in more tax avoidance. A solution to decrease this practice is to increase the reputation cost and fine simultaneously. The reputation cost can be increased by increasing the disclosure of tax avoidance cases.

In this part, we contribute to the literature in many ways. Unlike previous studies, we propose a theoretical model that analyzes the interplay among IRS, Banks and Non-banks. We also extend previous models by considering reputation costs. Moreover, this theoretical model can contribute to improving the tax collection policy and promotion of greater tax justice. 


\section{DO FINANCIAL INSTITUTIONS PRACTICE LESS TAX AVOID- ANCE THAN OTHER COMPANIES?}

This section examines the first result of the propositions and lemmas of our theoretical model based on game theory presented in the first part (Section 2), which shows Non-banks are more aggressive when practicing tax avoidance than Banks. Thus, in this part we examine whether financial institutions practice more tax avoidance than companies from other sectors because they have greater reputation costs. We predict that financial institutions have lower GAAP effective tax rates (GAAP ETRs) and CASH effective tax rates (CASH ETR) than companies from other sectors.

For the purpose of this part, we focus on all U.S. public firms. The sample is composed of 110,030 firm-years from the Compustat database covering the period 2000-2018. We perform regression with robust standard errors and we find that statistically there is no difference in the level of tax avoidance between financial companies and companies from other sectors. One explanation for this result is that as financial companies have higher reputation costs, so they are not as aggressive when practicing tax avoidance. However, when we perform sensitivity analysis by using quantile regression, we find that as the level of tax avoidance increases (quantiles), fewer financial companies practice tax avoidance. Moreover, in 2002 Sarbanes-Oxley Act was enacted, which required accountability, responsibility and transparency from publicly traded companies. To verify the effects of this law on tax avoidance practices, we carry out additional analysis by using Propensity Score Matching (PMS).

We conclude that this law forced public companies to be less aggressive when practicing tax avoidance. This topic has received little attention to date. Thus, this study is one of the first to compare tax avoidance of Financial and Non-financial companies. In this part, we contribute both to the tax avoidance literature and the literature on financial firms.

\subsection{Introduction}

In this part we test the first result obtained in the theoretical model based on game theory presented in Section 2. The propositions and lemmas developed in that section show that in equilibrium, Non-banks are more aggressive than Banks when practicing tax avoidance. Thus, we investigate whether financial institutions practice less tax avoidance than companies from other sectors. Our hypothesis is that they do because in general, financial institutions are large companies and according to Zimmerman (1983), large firms receive more attention from the government. Consequently, these companies have higher reputation costs. In recent decades, many studies have been published in this respect. So far, the results have been mixed. Moreover, these studies have not analyzed financial companies. Therefore, we extend the literature by examining tax avoidance in the context of financial companies and in the presence of high reputation costs. 
Using 110,030 U.S. public firm-year observations from Compustat covering the period 2000-2018, we show by performing regression with robust standard errors that statistically there is no difference in the level of tax avoidance of financial companies in comparison with companies from other sectors. We find this result by analyzing the tax avoidance measures with the control variables: R\&D, leverage, foreign operations, size, intangibles, property, plant, and equipment (PPE), ROA, and market-to-book (M/B). By including these control variables we can identify the real difference in the level of tax avoidance between Financial and Non-financial companies. The financial company variable captures the difference between financial and non-financial companies regarding tax avoidance.

However, when we perform sensitivity analysis by using quantile regression, we find that the higher the level of tax avoidance, the less tax aggressive financial companies tend to be. We also perform additional analysis to verify the effects of the Sarbanes-Oxley Act (an exogenous shock) on the level of tax avoidance by using Propensity Score Matching (PSM). We find that both from the point of view of GAAP ETR and CASH ETR, this law encouraged companies to be less aggressive. Interestingly, we find that financial institutions have had a higher level of tax avoidance since the passage of this law.

This part contributes to the literature in several ways. Our evidence enables a better understanding of the tax avoidance practices of Financial and Non-financial companies. Many studies have investigated tax avoidance from the agency theory perspective (Armstrong, Blouin, Jagolinzer, \& Larcker, 2015; Desai \& Dharmapala, 2008a; Khan, Srinivasan, \& Tan, 2017). Others have examined the connection between tax avoidance and corporate governance (Desai \& Dharmapala, 2008b; Desai, Dyck, \& Zingales, 2007; Hoi, Wu, \& Zhang, 2013; Minnick \& Noga, 2010).

Some studies have analyzed the connection between tax avoidance and reputation (Frischmann, Shevlin, \& Wilson, 2008; Graham \& Tucker, 2006; Hanlon \& Slemrod, 2009; Rego, 2003; Shackelford and Shevlin, 2001). In general, these studies have examined the CEO level. The traditional perspective is that reputation costs are an important aspect to limit CEOs and firms from engaging in tax avoidance. Generally, the studies of tax avoidance focus on Non-financial institutions. However, the financial crisis of 2007-2009 shows that it is very important to study financial institutions (Gallemore, Gipper, \& Maydew, 2019; Lobo, 2017; Walter, 2016).

We also contribute to the literature on tax avoidance and financial institutions. The previous studies have suggested that companies do not practice tax avoidance because of reputation concerns. However, the empirical evidence about this is scarce (Chyz \& Gaertner, 2018). Basically, the previous studies have focused on Non-financial companies. Thus, there is no existing study that compares the tax avoidance level of financial institutions with that of other companies. This study adds to the literature by providing evidence about how aggressive financial institutions are when practicing tax avoidance. We also contribute to the literature by analyzing the data after enactment of the Sarbanes-Oxley Act in 2002 through which we can verify the government's 
enforcement through the Internal Revenue Service (IRS). Finally, Hanlon and Heitzman (2010) suggested studying more financial institutions, motivated this research.

The rest of this section proceeds as follows. In Section 3.2 we review the related literature; Section 3.3 presents our hypothesis; Section 3.4 describes the sample and research design; Section 3.5 presents primary empirical analysis; and Section 3.6 concludes.

\subsection{Literature review}

Tax avoidance is a topic that has received the attention both of academics and practitioners in recent decades. The main point is that taxes represent a significant cost to companies. It is intuitive that companies and their shareholders want to use tax avoidance as a way to reduce the impact of taxes. However, this intuition does not consider the reputation costs, and companies need to consider the impacts on their reputation when they decide to practice tax avoidance. Studies of tax avoidance have focused on: a) agency theory; b) corporate governance; and c) reputation (more sparingly). Basically, academics have analyzed the setting without focusing on financial companies. Hence, in this part we help to fill this gap in the literature by comparing Financial and Non-financial companies.

\subsubsection{Tax avoidance and agency theory}

Many studies have investigated tax avoidance from the agency theory perspective. For example Slemrod (2004) offered an economic perspective on corporate tax noncompliance. He addressed the supply of corporate noncompliance and the need to modify the Allingham-Sandmo theoretical model so that it is applied to public companies. Thus, he analyzed proposals aimed at increasing the disclosure of corporate taxes.

Focused on another aspect of this issue, Chen \& Chu (2005) developed a theoretical model to investigate tax evasion. They found that tax evasion, at the individual level, is a portfolio selection problem, while corporate tax evasion in general is a more complex process. For example, when the business owner decides to evade taxes, in addition to putting his company at risk, he is also putting his employees at risk, which requires adjustment of the compensation policy.

Chen \& Chu (2005) highlighted that since tax evasion is illegal, the contract offered to the manager is incomplete. Consequently, this distorts his effort and also reduces the efficiency of the contract. Therefore, tax evasion increases the company's risk of being detected and also increases the cost because it increases the loss of efficiency of internal controls.

In contrast, Crocker \& Slemrod (2005) examined tax evasion at the company level, when analyzing the relation of contracts between the shareholders of a company and a tax manager who had privileged information about the dividing line between legal ways to reduce the taxable profit and illegal tax planning. Crocker \& Slemrod (2005) formalized an ideal incentive contract model 
for tax managers. They found that the form of the contract changes in response to the policies of the tax authority. Thus, the ideal contract should consider the effect of tax evasion penalties.

From the perspective of outcomes of tax avoidance, Desai \& Dharmapala (2008) considered the effect of tax evasion on the company's value. They found that this effect varies according to the level of corporate governance. Their results showed that the average effect of tax evasion on the company's value is negligible. However, they found a positive effect for companies with a high level of governance.

Expanding this analysis, Armstrong et al. (2015) examined the relation between corporate governance, managerial incentives and corporate tax evasion. They showed that due to the agency problem, managers can choose a different level of tax evasion than what shareholders would choose. In addition, no connection was found between corporate governance and tax evasion. However, they found that the independence of the board reduces the level of tax evasion.

Finally, Khan et al. (2017) presented new evidence about the connection between agency theory and tax avoidance of the companies by showing there is a positive relation between institutional ownership and tax avoidance. They also showed that managers use tax shelters in order to earn greater profits and thus meet or exceed analysts' expectations. Their results showed the existence of ownership concentration and ax evasion are related.

\subsubsection{Tax avoidance and corporate governance}

Other studies have investigated whether tax avoidance and corporate governance are related. For instance, Desai et al. (2007) analyzed whether there is a relation between company taxes and corporate governance. They showed that a way the company's tax system is designed affects the benefits of company members and that corporate governance affects the gains from tax changes.

Minnick \& Noga (2010), on the other hand, focused on the remuneration of mid-level managers and directors. They showed that remuneration is a way to encourage managers and directors to seek high performance in the long run. One way that managers and directors do this is by reducing taxable income. In addition, the authors highlighted that managers and directors use the strategy of making payments over a longer horizon to increase the performance of their tax planning. Thus, shareholders benefit by having higher returns.

Finally, Hoi et al. (2013) examined whether corporate social responsibility (CSR) and tax evasion are related. They found a positive relation between irresponsibility and tax evasion. Thus, the more irresponsible a company is, the greater the chances it will be involved in tax evasion. So, the company culture affects the level of tax evasion. 


\subsubsection{Tax avoidance and reputation}

Other studies have analyzed whether tax avoidance affects reputation. In general, these studies have been performed at the CEO level. For example, Dyreng, Hanlon, \& Maydew (2010) investigated whether tax avoidance affects executives. For that, they analyzed the data of 908 executives. Their results showed that executives affect the level of tax avoidance that the company will practice and the economic effect of this practice is large.

Rego \& Wilson (2012) examined this issue from the perspective of capital risk incentives. For them, this factor determines how aggressive companies will be when practicing tax avoidance. Since tax evasion strategies involve uncertainties, both companies and managers incur costs from this practice. Therefore, companies need to provide incentives for managers to be more aggressive in tax avoidance practices. Rego \& Wilson (2012) identified a relation between equity risk and more aggressive tax avoidance strategies.

Similarly, Chyz (2013) investigated whether executives send signals that they are more inclined to practice tax avoidance or not. Chyz (2013) found a relation between the presence of executives more likely to practice tax avoidance and the company's level of tax protection. In addition, he found that the presence of executives more inclined engage in tax avoidance generates tax savings.

According to the literature, companies should remunerate their executives based on profit after taxes. Thus, Gaertner (2014) examined whether a relation exists between CEO compensation based on profit after taxes and the level of corporate tax avoidance. To that end, he analyzed data about executive incentives and effective tax rates. He found that profit after taxes is positively related to executive pay and that for executives to be more aggressive when practicing tax avoidance, they need to be rewarded for taking on this risk.

Gallemore, Maydew, \& Thornock (2014) analyzed whether aggressive tax avoidance practices impose reputation costs on companies and executives. For that, they analyzed data from 118 companies that received more attention from society for being involved with tax shelters. Little evidence was found that involvement with tax shelters imposes a reputational cost. In addition, they found that these companies did not change their aggressive tax avoidance practices after being investigated. They concluded that, at the company level, there is little evidence that tax avoidance practices impose reputational costs.

Addressing the problem of tax avoidance from another angle, Chyz and Gaertner (2018) examined whether CEO turnover and taxes are related. In general, previous studies showed that the reputation cost generally discourages companies from practicing tax avoidance. Nonetheless, empirical evidence that this actually occurs is scarce. They found a relation between taxes paid and CEO turnover. In addition, they found that when the company pays more taxes, there is a forced turnover of CEOs.

Finally, Lanis et al. (2018) examined whether the reputation of the board of directors 
and the CEO is affected by tax avoidance. Interestingly, they found that when a firm practices tax avoidance, both it and its CEO are rewarded. The authors also showed empirically that tax avoidance and the reputation of CEOs are related.

\subsection{Hypothesis development}

Generally, the prior literature has focused on Non-financial institutions even though the financial crisis of 2007-2009 showed the relevance of studying the banking sector (Gallemore et al., 2019; Walter, 2016). Walter (2016) defined reputational risk and its determinants for large international banks in the context of transaction costs and imperfect information.

According to Gallemore et al. (2019), banks are means to facilitate the tax planning of their client companies. They found a relation between clients' own tax planning and the tax planning of the bank's other clients. Their results suggest that in addition to banks being financial intermediaries, they are also intermediaries in the tax planning process. Moreover, they found that bank loans are used as a means to achieve tax avoidance.

Thus, our hypothesis is based on the assumption that financial institutions practice less tax avoidance than other companies because, in general, they are large and are the focus of attention by the IRS, society and the media. Consequently, financial companies have higher reputation costs for practicing tax avoidance. For instance, in February 2015 The Guardian reported that the scandal about HSBC's systematic abetting of tax avoidance caused major damage to its reputation. Therefore, our hypothesis is:

H1: Financial institutions practice less tax avoidance than companies from other sectors.

\subsection{Sample and research design}

\subsubsection{Data and sample selection}

We focus on all U.S. public firms and the sample consists of 110,030 firm-years collected from Compustat covering the period 2000-2018. Of the 110,030 firm-year observations, over $7.60 \%$ refer to financial-firm observations, and $92.54 \%$ are non-financial firms. The sectors with more observations are Manufacturing (38.8\%), Mining, Quarrying, and Oil and Gas Extraction (13.6\%), and Information (10.9\%). The finance sector represents $7.5 \%$ of our sample. Previous studies have shown that the effective tax rate varies among sectors, so we cluster the sample for industry and year effects. Tables 3.1, 3.2 and 3.3 present the composition of the sample. 
Table 3.1 - Sample selection - Panel A

\begin{tabular}{ll}
\hline $\begin{array}{l}\text { Panel A: Sample composition } \\
\text { Description }\end{array}$ & No. of observations \\
\hline Full sample & 193,140 \\
Firms with total assets <1 million & $(9,571)$ \\
Missing GAAP ETR values & $(55,345)$ \\
Missing size values & $(9,159)$ \\
Missing leverage values & $(1,823)$ \\
Missing intangibles values & $(7,212)$ \\
\hline Final Sample & 110,030 \\
\hline
\end{tabular}

Table 3.2 - Sample selection - Panel B

Panel B: Distribution of observations of financial and non-financial firms by year

\begin{tabular}{llllll} 
Year & Financial & \% & Non-Financial & \% & Total \\
\hline 2000 & 406 & $5 \%$ & 6,234 & $6 \%$ & 6,640 \\
2001 & 388 & $5 \%$ & 6,010 & $6 \%$ & 6,398 \\
2002 & 381 & $5 \%$ & 5,862 & $6 \%$ & 6,243 \\
2003 & 390 & $5 \%$ & 5,772 & $6 \%$ & 6,162 \\
2004 & 406 & $5 \%$ & 5,823 & $6 \%$ & 6,229 \\
2005 & 416 & $5 \%$ & 5,794 & $6 \%$ & 6,210 \\
2006 & 444 & $5 \%$ & 5,860 & $6 \%$ & 6,304 \\
2007 & 459 & $6 \%$ & 5,875 & $6 \%$ & 6,334 \\
2008 & 441 & $5 \%$ & 5,484 & $5 \%$ & 5,925 \\
2009 & 438 & $5 \%$ & 5,263 & $5 \%$ & 5,701 \\
2010 & 447 & $5 \%$ & 5,270 & $5 \%$ & 5,717 \\
2011 & 460 & $6 \%$ & 5,206 & $5 \%$ & 5,666 \\
2012 & 477 & $6 \%$ & 5,311 & $5 \%$ & 5,788 \\
2013 & 491 & $6 \%$ & 5,295 & $5 \%$ & 5,786 \\
2014 & 493 & $6 \%$ & 5,272 & $5 \%$ & 5,765 \\
2015 & 483 & $6 \%$ & 4,991 & $5 \%$ & 5,474 \\
2016 & 449 & $5 \%$ & 4,760 & $5 \%$ & 5,209 \\
2017 & 442 & $5 \%$ & 4,650 & $5 \%$ & 5,092 \\
2018 & 298 & $4 \%$ & 3,089 & $3 \%$ & 3,387 \\
\hline Total & $\mathbf{8 , 2 0 9}$ & $\mathbf{1 0 0 \%}$ & $\mathbf{1 0 1 , 8 2 1}$ & $\mathbf{1 0 0 \%}$ & $\mathbf{1 1 0 , 0 3 0}$
\end{tabular}


Table 3.3 - Sample selection Panel C

\begin{tabular}{|c|c|c|c|}
\hline $\begin{array}{l}\text { Panel C: Industry } \\
\text { 2-Digit NAICS } \\
\text { Industry }\end{array}$ & $\begin{array}{l}\text { distribution of sample firm-years } \\
\text { Industry }\end{array}$ & No. of Observations & $\%$ \\
\hline 11 & $\begin{array}{l}\text { Agriculture, Forestry, Fishing and } \\
\text { Hunting }\end{array}$ & 423 & $0.4 \%$ \\
\hline 21 & $\begin{array}{l}\text { Mining, Quarrying, Oil and Gas Ex- } \\
\text { traction }\end{array}$ & 14,986 & $13.6 \%$ \\
\hline 22 & Utilities & 2,781 & $2.5 \%$ \\
\hline 23 & Construction & 1,534 & $1.4 \%$ \\
\hline $31-33$ & Manufacturing & 42,707 & $38.8 \%$ \\
\hline 42 & Wholesale Trade & 3,244 & $2.9 \%$ \\
\hline $44-45$ & Retail Trade & 4,255 & $3.9 \%$ \\
\hline $48-49$ & Transportation and Warehousing & 3,256 & $3.0 \%$ \\
\hline 51 & Information & 12,025 & $10.9 \%$ \\
\hline 52 & Finance and Insurance & 8,209 & $7.5 \%$ \\
\hline 53 & Real Estate and Rental and Leasing & 3,219 & $2.9 \%$ \\
\hline 54 & $\begin{array}{l}\text { Professional, Scientific, and Techni- } \\
\text { cal Services }\end{array}$ & 4,587 & $4.2 \%$ \\
\hline 55 & $\begin{array}{l}\text { Management of Companies and En- } \\
\text { terprises }\end{array}$ & 0 & $0.0 \%$ \\
\hline 56 & $\begin{array}{l}\text { Administrative and Support of Waste } \\
\text { Management and Remediation }\end{array}$ & 2,210 & $2.0 \%$ \\
\hline 61 & Educational Services & 550 & $0.5 \%$ \\
\hline 62 & Health Care and Social Assistance & 1,703 & $1.5 \%$ \\
\hline 71 & Arts, Entertainment, and Recreation & 779 & $0.7 \%$ \\
\hline 72 & Accommodation and Food Services & 1,787 & $1.6 \%$ \\
\hline 81 & $\begin{array}{l}\text { Other Services (except Public Ad- } \\
\text { ministration) }\end{array}$ & 1,775 & $1.6 \%$ \\
\hline & Total & 110,030 & $100 \%$ \\
\hline
\end{tabular}

\subsubsection{Research design}

In this part of the study we test the first result of the theoretical model based on game theory, according to which financial institutions are not more aggressive in practicing tax avoidance than companies from other sectors. The propositions and the lemmas of the theoretical model are presented in Section 2. We use a dummy variable that captures this result, Finance, and two measures of tax avoidance. We discuss each measure here. 
In the United States, the Sarbanes-Oxley Act of 2002 (SOX) requires more transparency from financial institutions. Beginning in 2002, the Internal Revenue Service (IRS) increased its attention on aggressive tax avoidance practices and also changed the regulation of these practices. Thus, we use this law as an exogenous shock.

To examine hypothesis, we use effective tax rate (ETR) as the measure of tax avoidance. Following Hanlon and Heitzman (2010), in this study tax avoidance is broadly defined. Thus, tax avoidance is a representation of tax planning practices. We use two measures, GAAP ETR and CASH ETR, to capture these practices.

According to Hanlon and Heitzman (2010), GAAP ETR is calculated by dividing total income tax expense by the accounting profit before taxes. Therefore, this measure is the total income tax liability. Moreover, according to those authors, a tax strategy that defers taxes will not change the GAAP ETR. However, the GAAP ETR may be impacted by several items that do not involve tax avoidance practices.

On the other hand, CASH ETR is calculated by dividing taxes paid by the accounting profit before taxes. This measure is impacted by deferred taxes, but it is not impacted by changes in accruals (Hanlon and Heitzman, 2010). Some studies have shown that the effective tax rates varies (Blouin, 2014; Dyreng et al., 2010). The choice between the two ETR measures is important because this sample (financial and non-financial institutions) has exogenous variation in reputation costs.

The first measure is GAAP ETR. According to Chen et al. (2010), this measure represents tax avoidance realized through permanent book-tax differences. Thus, with GAAP ETR analysis, managers can make better decisions. This measure also represents the total tax expense incurred, both current and deferred. Thus, one way to increase the company's profitability is to reduce the total tax expense. In summary, this measure is the total expense per dollar of book income (Hanlon \& Heitzman, 2010).

$$
\text { GAAP ETR }=\frac{\text { Total income tax expense }(\mathrm{TXT})}{\text { Pre-tax book income PI before special items }(\mathrm{SPI})}
$$

The second measure is the cash effective tax rate (CASH ETR). Deferred taxes impact this measure, but changes in the tax accounting accruals do. Thus, this measure captures the amount disbursed by the company to pay taxes. In summary, this measure represents the taxes paid per dollar of book income (Hanlon and Heitzman, 2010).

$$
\text { CASH ETR }=\frac{\text { Cash tax paid (TXPD) }}{\text { Pre-tax book income (PI)before special items (SPI) }}
$$

To test this hypothesis, we estimate the following regression and we use th control variables used in previous studies such as Leverage, Foreign Operations, Size, Intangibles, Gross PPE, and 
Market-to-Book.

$$
\begin{array}{r}
\text { TaxAvoid }_{i, t}=\alpha_{0}+\beta_{1} \text { Finance }_{i, t}+\beta_{2} \text { R\&D }_{i, t}+\beta_{3} \text { Levarage }_{i, t}+\beta_{4} \text { ForeingOperations }_{i, t} \\
+\beta_{5} \text { Size }_{i, t}+\beta_{6} \text { NOL }_{i, t}+\beta_{7} \text { Intangibles }_{i, t}+\beta_{8} \text { GrossPPE }_{i, t}+\beta_{9} \text { ROA }_{i, t} \\
+\beta_{10} \text { Market } \text { to }- \text { book }_{i, t}+\varepsilon_{i, t}
\end{array}
$$

Where TaxAvoid $_{i, t}$ is the tax avoidance measures discussed above; (1) Finance $_{i, t}$ is a dummy variable coded as one for financial firms; and zero otherwise; (2) $R \& D_{i, t}$ is calculated as Research and Development expense $(X R D)$ divided by net sales $(S A L E)$; when missing, reset to 0 ; (3) Leverage ${ }_{i, t}$ is defined as the sum of long-term debt $(D L T T)$ and current liabilities $(D L C)$ divided by total assets $(A T)$; (4) ForeignOperations $s_{i, t}$ indicates pre-tax income from foreign operations (PIFO); (5) Size $e_{i, t}$ is the natural log of total assets $(A T)$; (6) $N O L_{i, t}$ is a dummy variable indicating if the firm has a non-missing value of tax loss carry-forwards $(T L C F)$; (7) Intangibles $_{i, t}$ is the ratio of intangible assets $(I N T A N G)$ to total assets $(A T)$; (8) GrossPPE $E_{i, t}$ is Gross property, plant, and equipment (PPEGT) divided by total assets $(A T)$; (9) $R O A_{i, t}$ is Operating income before depreciation $(O I B D P)$ scaled by total assets $(A T)$; and (10) Market - to - Book $_{i, t}$ is the market value of equity $\left(P R C C_{F} \times C S H O\right)$ scaled by book value of equity $(C E Q)$. Continuous variables are winsorized at the $2.5 \%$ and $97.5 \%$ levels.

If financial firms are less tax aggressive than non-financial firms, we expect a negative coefficient for the Financial variable. We expect opposite signs if financial firms are more tax aggressive. We control for firm characteristics reported in the prior literature (Atwood, Drake, Myers, \& Myers, 2012; Cen, Maydew, Zhang, \& Zuo, 2017; S. Chen et al., 2010; James A. Chyz, 2013; Dyreng, Hanlon, \& Maydew, 2008; Dyreng et al., 2010; Gallemore et al., 2019; Lanis et al., 2018). The definitions of these variables are presented in Table 3.4. 
Table 3.4 - Variable measurement

\begin{tabular}{|c|c|c|c|c|c|}
\hline Item & Variable & Proxy & Definition & Used by & Database \\
\hline 1 & Dependent & GAAP ETR & GAAP ETR $=\frac{\text { Total income tax expense }(\mathrm{TXT})}{\text { Pre-tax book income(PI) before special items(SPI) }}$ & $\begin{array}{l}\text { Cen et al. (2017); } \\
\text { Dyreng et al. (2008); } \\
\text { Armstrong et al. (2015). }\end{array}$ & Compustat \\
\hline 2 & Dependent & Cash ETR & Cash ETR $=\frac{\text { Cash tax paid (TXPD) }}{\text { Pre-tax book income (PI)before special items (SPI) }}$ & $\begin{array}{l}\text { Cen et al. (2017); } \\
\text { Dyreng et al. (2008); } \\
\text { Armstrong et al. (2015). }\end{array}$ & Compustat \\
\hline 3 & Treatment & SOX & $\begin{array}{l}\text { This variable captures the effect of the Sarbanes-Oxley } \\
\text { Act. If the year is from } 2002 \text { to } 2018 \text {, this variable } \\
\text { assumes value of } 1 \text {, and } 0 \text { otherwise. }\end{array}$ & $\begin{array}{l}\text { Kim et al. (2011); } \\
\text { Halperin \& Lai (2014); } \\
\text { Engel et al. (2007). }\end{array}$ & Compustat \\
\hline 4 & Control & $R \& D$ & $\begin{array}{l}\text { Research and development expense (XRD) divided by } \\
\text { net sales (SALE); when missing, reset to } 0 \text {. }\end{array}$ & $\begin{array}{l}\text { Atwood et al. (2012); } \\
\text { Hoi et al. (2013); } \\
\text { Dyreng et al. (2008); } \\
\text { Lanis et al. (2018). }\end{array}$ & Compustat \\
\hline 5 & Control & Leverage & $\begin{array}{l}\text { The sum of long-term debt (DLTT) and current liabili- } \\
\text { ties (DLC) divided by total assets (AT) }\end{array}$ & $\begin{array}{l}\text { Cen et al. (2017); At- } \\
\text { wood et al. (2012); Hoi } \\
\text { et al. (2013); Dyreng et } \\
\text { al. (2008); Armstrong et } \\
\text { al. (2012); Lanis et al. } \\
\text { (2018). }\end{array}$ & Compustat \\
\hline 6 & Control & $\begin{array}{l}\text { Foreign op- } \\
\text { erations }\end{array}$ & $\begin{array}{l}\text { The firm has non-missing, non-zero value for pre-tax } \\
\text { income from foreign operations (PIFO) }\end{array}$ & & Compustat \\
\hline
\end{tabular}


Table 3.4 continued from previous page

\begin{tabular}{|c|c|c|c|c|c|}
\hline Item & Variable & Proxy & Definition & Used by & Database \\
\hline 7 & Control & Size & Natural log of total assets (AT) & $\begin{array}{l}\text { Armstrong et al. (2015); } \\
\text { Atwood et al. (2012); } \\
\text { Hoi et al. (2013); } \\
\text { Dyreng et al. (2008); } \\
\text { Lanis et al. (2018). }\end{array}$ & Compustat \\
\hline 8 & Control & $\begin{array}{l}\text { Net Operat- } \\
\text { ing Loss }\end{array}$ & $\begin{array}{l}\text { An indicator if the firm has a non-missing value of tax } \\
\text { loss carry-forwards (TLCF) }\end{array}$ & $\begin{array}{l}\text { Cen et al. (2017); Hoi et } \\
\text { al. (2013); }\end{array}$ & Compustat \\
\hline 9 & Control & $\begin{array}{l}\text { Intangibles } \\
\text { to total } \\
\text { assets }\end{array}$ & $\begin{array}{l}\text { The ratio of intangible assets (INTANG) to total assets } \\
\text { (AT) }\end{array}$ & $\begin{array}{l}\text { Cen et al. (2017); Hoi et } \\
\text { al. (2013); Dyreng et al. } \\
(2008) ;\end{array}$ & Compustat \\
\hline 10 & Control & $\begin{array}{l}\text { Gross } \\
\text { PP\&E to } \\
\text { total assets }\end{array}$ & $\begin{array}{l}\text { Gross property, plant, and equipment (PPE GT) divided } \\
\text { by total assets (AT) }\end{array}$ & $\begin{array}{l}\text { Cen et al. (2017); Hoi et } \\
\text { al. (2013); }\end{array}$ & Compustat \\
\hline 11 & Control & ROA & $\begin{array}{l}\text { Operating income before depreciation (OIBDP) scaled } \\
\text { by total assets (AT) }\end{array}$ & $\begin{array}{l}\text { Cen et al. (2017); At- } \\
\text { wood et al. (2012); Hoi } \\
\text { et al. (2013); Dyreng et } \\
\text { al. (2008); Armstrong et } \\
\text { al. (2015); Lanis et al. } \\
\text { (2018). }\end{array}$ & Compustat \\
\hline 12 & Control & $\begin{array}{l}\text { Market-to- } \\
\text { Book }\end{array}$ & $\begin{array}{l}\text { Market value of equity (PRCC_F x CSHO) scaled by } \\
\text { book value of equity (CEQ) }\end{array}$ & $\begin{array}{l}\text { Cen et al. (2017); Hoi et } \\
\text { al. (2013); }\end{array}$ & Compustat \\
\hline
\end{tabular}




\subsection{Empirical analysis}

\subsubsection{Primary empirical analysis}

Table 3.5 presents the descriptive statistics for the variables used in the analyses. The average of both GAAP ETR and CASH ETR is $14 \%$. The average firm has R\&D of 0.32, a leverage ratio of 0.19 , average size of $\$ 5.64$ million, average Net Operating Loss of 0.7 , and intangible asset ratio of 0.14. Furthermore, the average firm has Gross PPE to total assets of 0.50; and average ROA of 0.02. Hence, the average firm is not profitable. Finally, the average firm in the sample has Market to Book of 3.76.

Table 3.5 - Descriptive statistics

\begin{tabular}{lllllllll}
\hline Variables & N & Mean & SD & Min & P25 & P50 & P75 & Max \\
\hline GAAP ETR & 110,030 & 0.14 & 0.52 & -2.48 & 0.00 & 0.15 & 0.34 & 2.21 \\
CASH ETR & 86,803 & 0.14 & 0.38 & -1.50 & 0.00 & 0.09 & 0.27 & 1.92 \\
Finance & 110,030 & 0.07 & 0.26 & 0.00 & 0.00 & 0.00 & 0.00 & 1.00 \\
R\&D & 110,030 & 0.32 & 1.84 & 0.00 & 0.00 & 0.00 & 0.04 & 11.23 \\
Leverage & 110,030 & 0.19 & 0.20 & 0.00 & 0.00 & 0.15 & 0.32 & 0.75 \\
Foreign Operations & 110,030 & 0.31 & 0.46 & 0.00 & 0.00 & 0.00 & 1.00 & 1.00 \\
Size & 110,030 & 5.64 & 2.48 & 0.69 & 3.80 & 5.56 & 7.37 & 11.60 \\
Net Operating Loss & 110,030 & 0.70 & 0.46 & 0.00 & 0.00 & 1.00 & 1.00 & 1.00 \\
Intangibles to total assets & 110,030 & 0.14 & 0.19 & 0.00 & 0.00 & 0.04 & 0.22 & 0.77 \\
Gross PPE to total assets & 110,030 & 0.50 & 0.44 & 0.00 & 0.13 & 0.37 & 0.79 & 1.96 \\
ROA & 110,030 & 0.02 & 0.29 & -1.46 & -0.03 & 0.08 & 0.14 & 0.41 \\
Market to Book & 110,030 & 3.76 & 7.57 & 0.17 & 1.07 & 1.90 & 3.55 & 44.34 \\
\hline
\end{tabular}

Table 3.6 presents the Pearson and Spearman correlations of the regression variables used in this part of the study. GAAP ETR has a significant positive relation with Finance $\left(0.0089^{a s t}\right)$. However, the magnitude of this relation is not high. But when considering CASH ETR, this coefficient has greater magnitude $\left(0.0203^{*}\right)$. R\&D presents a significant and negative relation $\left(-0.0412^{*}\right)$ with GAAP ETR. This relation continues when analyzing CASH ETR $\left(-0.0419^{*}\right)$. It indicates that firms that practice less tax avoidance invest less in research and development. Leverage has a significant and positive relation $\left(0.0213^{*}\right)$ with GAAP ETR and a significant and negative relation $(-0.0094)$ with CASH ETR. 
Table 3.6 - Pearson (below) and Spearman (above) correlations of

tax avoidance measures

\begin{tabular}{|c|c|c|c|c|c|c|c|c|c|c|c|c|c|}
\hline & Variables & 1 & 2 & 3 & 4 & 5 & 6 & 7 & 8 & 9 & 10 & 11 & 12 \\
\hline \multirow[t]{2}{*}{1} & GAAP & 1 & $0.4302^{*}$ & $0.0269^{*}$ & $-0.1662 *$ & $0.0506^{*}$ & $0.0108^{*}$ & $0.2045^{*}$ & -0.0013 & $0.0627^{*}$ & $0.0714^{*}$ & $0.3846^{*}$ & -0.0046 \\
\hline & ETR & & & & & & & & & & & & \\
\hline \multirow[t]{2}{*}{2} & CASH & $0.1627^{*}$ & 1 & $0.0444 *$ & $-0.0937 *$ & $0.0229^{*}$ & $0.1208^{*}$ & $0.2930^{*}$ & $0.0295^{*}$ & $0.1602^{*}$ & $-0.0074 *$ & $0.4921 *$ & $0.0811 *$ \\
\hline & ETR & & & & & & & & & & & & \\
\hline 3 & Finance & $0.0089^{*}$ & $0.0203^{*}$ & 1 & $-0.1962 *$ & $-0.0204^{*}$ & $-0.1013^{*}$ & $0.1172 *$ & $0.0105^{*}$ & $-0.0943^{*}$ & $-0.3454^{*}$ & $-0.0866^{*}$ & $-0.0881^{*}$ \\
\hline 4 & $\mathrm{R} \& \mathrm{D}$ & $-0.0412 *$ & $-0.0419 *$ & $-0.0448^{*}$ & 1 & $-0.2411^{*}$ & $0.3112 *$ & $-0.1022 *$ & $0.0195^{*}$ & $0.1690^{*}$ & $-0.2068 *$ & $-0.1128 *$ & $0.2130 *$ \\
\hline 5 & Leverage & $0.0213^{*}$ & $-0.0094 *$ & 0.0017 & $-0.0889 *$ & 1 & -0.0014 & $0.3814 *$ & $-0.0376^{*}$ & $0.1950^{*}$ & $0.2384 *$ & $0.1178^{*}$ & $-0.0249 *$ \\
\hline \multirow[t]{2}{*}{6} & Foreign & $0.0228 *$ & $0.0522 *$ & $-0.0982 *$ & $-0.0432 *$ & 0.0014 & 1 & $0.2694 *$ & $0.0433^{*}$ & $0.2464 *$ & $-0.0702 *$ & $0.1124 *$ & $0.1236^{*}$ \\
\hline & $\begin{array}{l}\text { Opera- } \\
\text { tions }\end{array}$ & & & & & & & & & & & & \\
\hline 7 & Size & $0.1141 *$ & $0.1236^{*}$ & $0.1092^{*}$ & $-0.1223^{*}$ & $0.3425^{*}$ & $0.2767 *$ & 1 & $-0.0127 *$ & $0.2738^{*}$ & $0.0881^{*}$ & $0.3291 *$ & $0.0493 *$ \\
\hline 8 & NOL & -0.0055 & $0.0187^{*}$ & $0.0157^{*}$ & $0.0111 *$ & $-0.0294 *$ & $0.0372^{*}$ & $-0.0186^{*}$ & 1 & $0.0225^{*}$ & $-0.0563^{*}$ & $0.0251^{*}$ & $0.0393 *$ \\
\hline 9 & Intangibles & $0.0177^{*}$ & $0.0456^{*}$ & $-0.0824 *$ & $-0.0345^{*}$ & $0.1628^{*}$ & $0.1860 *$ & $0.1983^{*}$ & $0.0208 *$ & 1 & $-0.2537 *$ & $0.1798^{*}$ & $0.1356^{*}$ \\
\hline 10 & PPE & $0.0314^{*}$ & $-0.0165^{*}$ & $-0.2619 *$ & $-0.1139 *$ & $0.2074 *$ & $-0.0921 *$ & $0.0921 *$ & $-0.0455^{*}$ & $-0.2920 *$ & 1 & $0.2214^{*}$ & $-0.0860^{*}$ \\
\hline 11 & ROA & $0.1215^{*}$ & $0.1612^{*}$ & $0.0404 *$ & $-0.3349 *$ & $0.1729^{*}$ & $0.1560^{*}$ & $0.4555^{*}$ & -0.003 & $0.1134 *$ & $0.1323^{*}$ & 1 & $0.2444 *$ \\
\hline 12 & $\begin{array}{l}\text { Market- } \\
\text { to-Book }\end{array}$ & $-0.0263^{*}$ & $-0.0251^{*}$ & $-0.0485^{*}$ & $0.0772 *$ & $0.0503^{*}$ & -0.0039 & $-0.1515^{*}$ & $0.0215^{*}$ & -0.0009 & $-0.0802 *$ & $-0.2098 *$ & 1 \\
\hline
\end{tabular}


Foreign Operations presents a significant and positive relation both with GAAP ETR $\left(0.0228^{*}\right)$ and CASH ETR $\left(0.0522^{*}\right)$. This indicates that firms that practice less tax avoidance have more pre-tax income from foreign operations. Size has a significant and positive relation both with GAAP ETR $\left(0.1141^{*}\right)$ and CASH ETR $\left(0.1236^{*}\right)$. These results indicate that firms that practice less tax avoidance are larger. NOL (Net Operating Loss) has a negative, but not significant, relation with GAAP ETR $(-0.0055)$. However, when considering CASH ETR, the coefficient is positive and significant $\left(0.0187^{*}\right)$. It can be inferred that from the perspective of CASH ETR, less aggressive firms have higher tax loss carryforwards.

Finally, Intangibles has a significant and positive relation both with GAAP ETR $\left(0.0177^{*}\right)$ and CASH ETR $\left(0.0456^{*}\right)$. Hence, these results indicate that firms that are less aggressive have more intangibles to total assets. PPE (Property, plant, and equipment) presents a positive and significant relation with GAAP ETR $\left(0.0314^{*}\right)$ and a significant, but negative relation with CASH ETR $\left(-0.0165^{*}\right)$. ROA presents a significant and positive relation both with GAAP ETR $\left(0.1215^{*}\right)$ and CASH ETR $\left(0.1612^{*}\right)$. This indicates that firms that practice less aggressive tax avoidance are more profitable. Market-to-Book has a significant and positive relation both with GAAP ETR $\left(-0.0263^{*}\right)$ and CASH ETR $\left(-0.0263^{*}\right)$.

Table 3.7 shows the results of the difference of means between Financial and NonFinancial institutions. Both GAAP ETR and CASH ETR indicate a statistical difference between these two groups. Here we find some evidence that financial institutions practice less tax avoidance than companies from other sectors. However, it is necessary to perform more tests to confirm this result.

Table 3.7 - Difference of means

\begin{tabular}{|c|c|c|c|c|c|c|c|}
\hline \multirow[b]{2}{*}{ Variables } & \multicolumn{3}{|c|}{ Financial } & \multicolumn{4}{|c|}{ Non-Financial } \\
\hline & Mean & P50 & SD & Mean & P50 & SD & Difference of means \\
\hline GAAP ETR & 0.16 & 0.18 & 0.44 & 0.14 & 0.15 & $\mathbf{0 . 5 3}$ & $-0.017 * *$ \\
\hline CASH ETR & 0.17 & 0.14 & 0.37 & 0.14 & 0.08 & 0.38 & $-0.029 * * *$ \\
\hline $\mathrm{R} \& \mathrm{D}$ & 0.03 & 0.00 & 0.50 & 0.34 & 0.00 & 1.90 & $0.313 * * *$ \\
\hline Leverage & 0.19 & 0.09 & 0.23 & 0.19 & 0.15 & 0.19 & -0.001 \\
\hline Foreign Operations & 0.15 & 0.00 & 0.36 & 0.33 & 0.00 & 0.47 & $0.173 * * *$ \\
\hline Size & 6.60 & 6.50 & 2.79 & 5.56 & 5.48 & 2.44 & $-1.031 * * *$ \\
\hline Net Operating Loss & 0.73 & 1.00 & 0.45 & 0.70 & 1.00 & 0.46 & $-0.027 * * *$ \\
\hline Intangibles to total assets & 0.09 & 0.00 & 0.17 & 0.15 & 0.05 & 0.20 & $0.060 * * *$ \\
\hline Gross PPE to total assets & 0.09 & 0.02 & 0.21 & 0.53 & 0.42 & 0.44 & $0.437 * * *$ \\
\hline ROA & 0.04 & 0.04 & 0.17 & 0.00 & 0.08 & 0.30 & $-0.044 * * *$ \\
\hline Market to Book & 2.47 & 1.19 & 4.87 & 3.87 & 1.97 & 7.74 & $1.397 * * *$ \\
\hline
\end{tabular}


We estimated Equation 3.3 using ordinary least squares (OLS) and panel data. In this study we use panel data analysis as another econometric strategy because of the characteristics of the sample, since the data set used in this study has a cross-sectional and temporal dimension, given that the sample of companies $(i=1,2, \ldots, 110,030)$ will be observed over time $(t=2000, \ldots$, 2018).

The data arranged in cross section and in time series are referred to in the econometric literature as panel data or longitudinal data. Thus, the panel data technique aims to study the influence of explanatory variables on the dependent variable for a set of observations over time (Wooldridge, 2010).

The econometric approach to panel data has some advantages. According to Greene (2011), the fundamental advantage of a panel of data distributed over a cross section is that it allows the researcher great flexibility in differences in behavior modeling between individuals. Wooldridge (2010) states that the main motivation for using panel data is to solve the problem of omitted variables. According to Cameron and Trivedi (2005), a major advantage of the data panel is the increase in precision of the estimate.

Finally, Brooks (2008) has three advantages of using the panel data structure: a) it is possible to address a broader range of issues and solve the most complex problems with panel data; and b) it is often interesting to examine how variables or the relation between them change dynamically (over time), which is possible by combining cross-sectional data and time series. Thus, increasing the number of degrees of freedom and, consequently, the power of the test; and c) one can remove the impact of the bias of the variables omitted in the regression.

There are several models that can use panel data. According to Greene (2011), they are distinguished by the presence of fixed or random effects. The fixed effect model considers that $\beta_{0}=0$. On the other hand, in random effect models, it is assumed that $\beta_{0}=0$ is exclusively random and not a constant. Therefore, it is not correlated with the regressors. Thus, the main difference between both approaches is in the relation between unobserved heterogeneity and explanatory variables (Wooldridge, 2010).

The dependent variable and the regressors can vary over time and also between individuals. The variation over time or for a given individual is called within variance, while the variation between individuals is known as between variance. According to Wooldridge (2010), in the fixed effects models, the coefficient of a regressor with low variation within will not be precisely estimated. Therefore, it will not be identified if there is no within variance.

Panel data can be of two types: a) balanced panel - occurs when each cross-sectional unit has the same number of observations; and b) unbalanced panel - when each unit has a different number of observations (Gujarati \& Porter, 2011). In this study, the companies in the sample did not have data for the analysis period, the data panel is unbalanced. In general, in empirical research involving longitudinal data, the parameters of the models are generally estimated using 
the Ordinary Least Squares (OLS) method or fixed effects and random effects approaches. In the OLS method, the data is grouped in a single moment in time and it is assumed that the observations are independent of each other. Thus, for the coefficients estimated by the OLS method to be consistent, it is necessary that there is no contemporary correlation between the model's error term and the explanatory variables (Wooldridge, 2010).

One way to choose the most appropriate method of estimating the model parameters is to verify the existence of a correlation between the unobserved heterogeneity and the explanatory variables when comparing the estimates obtained by each of the aforementioned approaches. Wooldridge (2010) suggests the application of the test developed by Hausman. The null hypothesis (H0) of this test is that the differences between the coefficients estimated by the method of Fixed Effects and Random Effects are not systematic. Therefore, they are not statistically significant. When the null hypothesis of this test is rejected, it is interpreted that there is evidence of a correlation between the individual effects and the regressors, that is, it is understood as evidence contrary to the estimation by Random Effects.

In this study, before performing the Hausman test, the Chow test was performed in order to verify the adequacy of the relationship between the variables when testing the equality of the regressors in two linear regressions assuming a common variance. Thus, the hypotheses of this test are: H0: Restricted model (pooled) and H1: Unrestricted model - panel data with fixed effects (Cameron; Trivedi, 2009).

Then, the assumptions underlying the consistency of the fixed and random effects of the estimators were formally tested. Thus, the Hausman test was performed, in which it was possible to test the strict exogeneity. The hypotheses of this test are: H0: Random effects model and H1: Fixed effects model (Wooldridge, 2011).

Checking the presence of homogeneity, the Breushc-Pagan test was performed. The hypotheses of this test are: H0: Homoscedasticity in the model and H1: Heteroscedasticity in the model. To verify the existence of autocorrelation, the Wooldridge test was performed. Thus, the hypotheses of this test are: H0: Absence of autocorrelation in the model and H1: Presence of autocorrelation in the model (Wooldridge, 2011).

Finally, standard errors were adjusted for heteroscedasticity, serial and transversal correlation by using a two-dimensional cluster at the company and year level. According to Petersen (2009), in studies in corporate finance that use panel data the most appropriate to estimate standard errors is it.

Table $3.8^{1}$ presents the primary results regarding the relation between financial firms and tax avoidance from perspective of GAAP ETR.

1 Following the results from the tests: Chow test: 0.000 - we find that panel data is preferable over pooled model. Hausman test: 0.1430 - we find that the appropriate model is random effects. Breush-Pagan test: 0.000 - we find did not confirm that the observations are homoscedastic. However, by using robust errors we deal with this issue. Wooldridge test: 0.643 - we accept the null hypothesis that there is no autocorrelation issue. 
Table 3.8 - Tax avoidance of Financial and Non-financial firms (GAAP ETR)

\begin{tabular}{|c|c|c|}
\hline & (1) & (2) \\
\hline Variables & OLS & Random Effects \\
\hline \multirow[t]{2}{*}{ Finance } & 0.000 & 0.000 \\
\hline & {$[0.005]$} & {$[0.007]$} \\
\hline \multirow[t]{2}{*}{$\mathrm{R} \& \mathrm{D}$} & $-0.001 * * *$ & $-0.001 * * *$ \\
\hline & {$[0.001]$} & [0.001] \\
\hline \multirow[t]{2}{*}{ Leverage } & $-0.074 * * *$ & $-0.074 * * *$ \\
\hline & {$[0.009]$} & {$[0.010]$} \\
\hline \multirow[t]{2}{*}{ Foreign Operations } & $-0.015 * * *$ & $-0.015 * * *$ \\
\hline & {$[0.003]$} & {$[0.004]$} \\
\hline \multirow[t]{2}{*}{ Size } & $0.018 * * *$ & $0.018 * * *$ \\
\hline & {$[0.001]$} & {$[0.001]$} \\
\hline \multirow[t]{2}{*}{ NOL } & -0.003 & -0.004 \\
\hline & {$[0.003]$} & {$[0.003]$} \\
\hline \multirow[t]{2}{*}{ Intangibles } & 0.007 & 0.007 \\
\hline & {$[0.009]$} & [0.010] \\
\hline \multirow[t]{2}{*}{ Gross PPE } & $0.020 * * *$ & $0.020 * * *$ \\
\hline & {$[0.004]$} & {$[0.004]$} \\
\hline \multirow[t]{2}{*}{ ROA } & $0.156^{* * *}$ & $0.154 * * *$ \\
\hline & {$[0.003]$} & {$[0.004]$} \\
\hline \multirow[t]{2}{*}{ Market to Book } & $0.001 * * *$ & $0.001 * *$ \\
\hline & {$[0.001]$} & {$[0.001]$} \\
\hline \multirow[t]{2}{*}{ Constant } & $0.045^{* * *}$ & $0.045 * * *$ \\
\hline & {$[0.005]$} & {$[0.006]$} \\
\hline Observations & 110,030 & 110,030 \\
\hline Number of firms & 14,817 & 14,817 \\
\hline Year dummies & Yes & Yes \\
\hline R-Squared / Between & 0.0201 & 0.0567 \\
\hline
\end{tabular}

Robust standard errors in brackets

$* * * \mathrm{p}<0.01, * * \mathrm{p}<0.05, * \mathrm{p}<0.10$

OLS estimate of the conditional mean of tax avoidance and panel data provide no evidence of a relation between Finance and tax avoidance GAAP ETR. In the both regressions, the coefficient of Finance is zero (0.000) and not significant. Thus, we did not find evidence that financial companies practice less tax avoidance than companies from other sectors. 
Contrary to prior studies that have found a positive relation between $\mathbf{R} \& \mathbf{D}$ expenditures and tax avoidance (Dyreng et al., 2008; Atwood et al., 2012) and no association between tax avoidance and $\mathbf{R} \& \mathbf{D}$, we find a negative association between tax avoidance and $\mathbf{R} \boldsymbol{\& D}$ in in the two model, this relation is significant. Unlike prior research that has found a positive association between tax avoidance and Leverage (Dyreng et al., 2008; Atwood et al., 2012), we find a negative association in both regressions.

In relation to Foreign Operations, previous results are inconclusive. For example, Rego (2003) and Atwood et al. (2012) found that multinationals practice less tax avoidance than domestic firms. On the other hand, Wilson (2009) reported that firms with foreign income are more likely to be tax-shelter participants. Our results from perspective GAAP ETR are more consistent with those found in Armstrong et al. (2015) and Rego (2003). We find a negative and significant coefficient for the Foreign Operations variable.

Like to Rego (2003), who found a positive and significant relation between Size and tax avoidance, we find a positive and significant relation between size and GAAP ETR. Thus, we find that large firms practice more tax avoidance. Concerning to NOL, we find a positive, but not significant coefficient in both regressions. Thus, we did not find evidence about the relation between NOL and GAAP ETR.

Regarding Intangibles, when analyzing the relation between Intangibles and GAAP ETR we find a positive but not significant coefficient in both regressions. With respect to PPE, we find a positive and significant coefficient between PPE and GAAP ETR in both regressions. Concerning to ROA, we find a positive and significant coefficient in both regressions. Finally, we also find a positive and significant coefficient between Market-to-Book and GAAP ETR.

Table $3.9^{2}$ presents the primary results regarding the relation between financial firms and tax avoidance from perspective of CASH ETR presents the primary results regarding the relation between financial firms and tax avoidance from perspective of CASH ETR.

Table 3.9 - Tax avoidance of Financial and Non-financial firms (CASH ETR)

\begin{tabular}{lcc}
\hline & $(1)$ & $(2)$ \\
Variables & OLS & Random Effects \\
\hline \multirow{2}{*}{ Finance } & & \\
& $\mathbf{0 . 0 0 7}$ & $\mathbf{0 . 0 0 8}$ \\
R\&D & {$[\mathbf{0 . 0 0 5}]$} & {$[\mathbf{0 . 0 0 6}]$} \\
& $0.001 * * *$ & $0.001 * *$ \\
& {$[0.001]$} & {$[0.001]$} \\
\hline
\end{tabular}

2 Following the results from the tests: Chow test: 0.000 - we find that panel data is preferable over pooled model. Hausman test: 0.1752 - we find that the appropriate model is random effects. Breush-Pagan test: 0.000 - we find did not confirm that the observations are homoscedastic. However, by using robust errors we deal with this issue. Wooldridge test: 0.0133 - we accept the null hypothesis that there is no autocorrelation issue. 
Table 3.9 continued from previous page

\begin{tabular}{|c|c|c|}
\hline & OLS & Random Effects \\
\hline \multirow[t]{2}{*}{ Leverage } & $-0.099 * * *$ & $-0.093 * * *$ \\
\hline & {$[0.007]$} & {$[0.008]$} \\
\hline \multirow[t]{2}{*}{ Foreign Operations } & 0.004 & 0.004 \\
\hline & {$[0.002]$} & {$[0.003]$} \\
\hline \multirow[t]{2}{*}{ Size } & $0.013 * * *$ & $0.014 * * *$ \\
\hline & {$[0.001]$} & {$[0.001]$} \\
\hline \multirow[t]{2}{*}{ NOL } & $0.013 * * *$ & $0.012 * * *$ \\
\hline & {$[0.002]$} & {$[0.003]$} \\
\hline \multirow[t]{2}{*}{ Intangibles } & $0.035 * * *$ & $0.032 * * *$ \\
\hline & {$[0.007]$} & {$[0.008]$} \\
\hline \multirow[t]{2}{*}{ Gross PPE } & $-0.016 * * *$ & $-0.016 * * *$ \\
\hline & {$[0.003]$} & [0.004] \\
\hline \multirow[t]{2}{*}{ ROA } & $0.222 * * *$ & $0.200 * * *$ \\
\hline & {$[0.004]$} & {$[0.005]$} \\
\hline \multirow[t]{2}{*}{ Market to Book } & $0.001 * * *$ & $0.001 * * *$ \\
\hline & {$[0.000]$} & {$[0.000]$} \\
\hline \multirow[t]{2}{*}{ Constant } & $0.058 * * *$ & $0.053 * * *$ \\
\hline & {$[0.004]$} & {$[0.005]$} \\
\hline Observations & 86,803 & 86,803 \\
\hline Number of firms & 12,098 & 12,098 \\
\hline Year dummies & Yes & Yes \\
\hline R-Squared / Between & 0.0340 & 0.0882 \\
\hline
\end{tabular}

Robust standard errors in brackets $* * * \mathrm{p}<0.01, * * \mathrm{p}<0.05, * \mathrm{p}<0.10$

From perspective of CASH ETR, we find a positive coefficient but not significant in both regressions. Therefore, we do not have evidence that financial firms practice less tax avoidance. An explanation for the results that we find in GAAP ETR and CASH ETR regressions is that since financial companies have a higher reputation cost, this makes them less aggressive when engaging in tax avoidance.

Like prior studies that have found a positive relation between R\&D and CASH ETR (Dyreng et al., 2008; Atwood et al., 2012). Unlike prior research (Dyreng et al., 2008; Atwood et al., 2012) that has found a positive association between tax avoidance and Leverage, we find a negative association in both regressions. In relation to Foreign Operations, from perspective of CASH ETR we find a positive and not significant relation between these variables. Thus, we do not fin evidence that these two variables are related. Concerning to Size, we find a positive and 
significant coefficient between this variable and CASH ETR for the two regressions. Therefore, large firms practice more tax avoidance.

In both regressions we find that there are a positive and significant relation between NOL and CASH ETR. Regarding Intangibles our results show that there is a positive and significant relation between Intangibles and CASH ETR. With respect to PPE our results show that there a negative and significant relation between PPE and CASH ETR. Concerning profitability, we find a positive and significant coefficient between ROA and CASH ETR in both regressions. These results suggest that large firms practice more tax avoidance. This result is similar to the results found in previous studies (Rego, 2003; Wilson, 2009). Finally, we find a positive and significant coefficient between Market-to-Book and CASH ETR in both regressions.

It is important to highlight that as our results are very different from previous studies, we analyzed the data separately. We analyzed only non-financial institutions and we find results more similar to the previous studies. However, when we analyze non-financial and financial institutions jointly, we find results very different from the previous studies. An explanation for this is that financial institutions have particular characteristics that affect the results.

\subsubsection{Sensitivity analysis}

In this section, we investigate whether the level of tax avoidance differs among the quantiles. For this, we perform Quantile Regression and Ordinary Least Squares (OLS) regressions. OLS regression relies on minimizing the least squares of the parameters, while quantile regression involves minimizing the weighted absolute errors. The second method minimizes the effects of outliers, and when data do not have normal distribution (assumption for regression), it presents better results when estimating the central position of the distribution (Clout, Falta, \& Willett, 2015; Koenker, 2004; Koenker, Bassett, \& Jan, 2007).

In this study, we use three quantiles: $0.10 ; 0.50$ and 0.90 . In our case, we interpret that the quantile 0.10 is composed by companies more aggressive. The quantile 0.50 is composed by the median. Finally, in the quantile 0.90 is composed by companies less aggressive. According to Table 3.10, in quantile 0.10 , the group of the companies more aggressive when practicing tax avoidance, financial institutions pay more taxes, about $1.35 \%$ more in taxes. Therefore, in the group composed by companies more aggressive, financial institutions are less aggressive. However, in quantiles 0.50 and 0.90, they engage in less aggressive GAAP ETR than other companies. In the quantile 0.90 , the group of the companies less aggressive, financial institutions are more aggressive when practicing tax avoidance. They pay about $2.30 \%$ less taxes. Thus, as the level of GAAP ETR increases, financial institutions become more aggressive when practicing tax avoidance. From the perspective of CASH ETR, the results show that in the quantile 0.10 and 0.90 there is no statistical difference. However, we find that in the quantile 0.50 (median) financial institutions pay about $0.2 \%$ more taxes. Thus, they are less aggressive when practicing tax avoidance than non-financial institutions. 
These results are important because they shed light on a problem not previously explored in the literature. Especially, because we find no difference about tax avoidance practices by using OLS method and panel data. However, when we use quantile regression, we can analyze the research question from other perspective and see how the GAAP ETR and CASH ETR variables vary over the quantiles. 
Table 3.10 - Quantile regression GAAP ETR

\begin{tabular}{|c|c|c|c|c|c|c|c|c|c|c|c|c|}
\hline \multirow{3}{*}{ Variables } & \multicolumn{6}{|c|}{ GAAP ETR (1) } & \multicolumn{6}{|c|}{ CASH ETR (2) } \\
\hline & \multicolumn{2}{|c|}{ Quantile 0.10} & \multicolumn{2}{|c|}{ Quantile 0.50} & \multicolumn{2}{|c|}{ Quantile 0.90} & \multicolumn{2}{|c|}{ Quantile 0.10} & \multicolumn{2}{|c|}{ Quantile 0.50} & \multicolumn{2}{|c|}{ Quantile 0.90} \\
\hline & Coef. & p-value & Coef. & $\mathrm{p}$-value & Coef. & $\mathrm{p}$-value & Coef. & $\mathrm{p}$-value & Coef. & p-value & Coef. & p-value \\
\hline Finance & 0.0135 & $0.000 * * *$ & -0.0162 & $0.000 * * *$ & -0.0089 & $0.023^{* * *}$ & -0.0019 & 0.633 & 0.0101 & $0.002 * *$ & 0.0059 & 0.370 \\
\hline $\mathrm{R} \& \mathrm{D}$ & 0.0005 & 0.000 & -0.0021 & 0.000 & -0.0064 & 0.000 & 0.0044 & 0.000 & 0.0008 & 0.057 & -0.0051 & 0.000 \\
\hline Leverage & -0.1253 & 0.000 & -0.0949 & 0.000 & 0.0782 & 0.000 & -0.1028 & 0.000 & -0.1304 & 0.000 & 0.0152 & 0.209 \\
\hline Foreign Operations & -0.0761 & 0.000 & 0.0019 & 0.334 & 0.005 & 0.168 & -0.0278 & 0.000 & 0.0177 & 0.000 & 0.012 & 0.012 \\
\hline Size & 0.0082 & 0.000 & 0.0274 & 0.000 & 0.0023 & 0.000 & 0.0091 & 0.000 & 0.0188 & 0.000 & 0.0041 & 0.003 \\
\hline NOL & 0.0035 & 0.068 & -0.0007 & 0.669 & -0.0039 & 0.170 & 0.0122 & 0.000 & 0.0119 & 0.000 & 0.0024 & 0.539 \\
\hline Intangibles & -0.0655 & 0.000 & 0.0681 & 0.000 & 0.0055 & 0.408 & 0.0264 & 0.000 & 0.0728 & 0.000 & -0.0186 & 0.093 \\
\hline Gross PPE & -0.0055 & 0.087 & 0.0381 & 0.000 & 0.0174 & 0.000 & -0.0094 & 0.001 & -0.0124 & 0.000 & -0.0214 & 0.004 \\
\hline $\mathrm{ROA}$ & -0.0269 & 0.000 & 0.1343 & 0.000 & 0.1964 & 0.000 & 0.1288 & 0.000 & 0.1584 & 0.000 & 0.2118 & 0.000 \\
\hline Market to Book & 0.0004 & 0.000 & 0.0009 & 0.000 & -0.0018 & 0.000 & 0.0017 & 0.000 & 0.002 & 0.000 & -0.0019 & 0.000 \\
\hline $\mathrm{N}$ of observations & 110,030 & & & & & & $\mathrm{~N}$ of observations & 86,803 & & & & \\
\hline 0.10 Pseudo R2 & 0.0080 & & & & & & 0.10 Pseudo R2 & 0.010 & & & & \\
\hline 0.50 Pseudo R2 & 0.0974 & & & & & & 0.50 Pseudo R2 & 0.0861 & & & & \\
\hline 0.90 Pseudo R2 & 0.0247 & & & & & & 0.90 Pseudo R2 & 0.0202 & & & & \\
\hline & & $\mathrm{p}<0.01, * *$ & $\mathrm{p}<0.05, *$ & $0<0.10$ & & & & $* * \mathrm{p}<0.0$ & , ** $\mathrm{p}<0.0$ & $5, * \mathrm{p}<0.10$ & & \\
\hline
\end{tabular}




\subsubsection{Additional analysis}

One of the problems of analyzing causal effects in econometrics is endogeneity. Many studies have shown that endogeneity is a big issue for academics because it biases effects (Hamilton, \& Nickerson, 2003; Li, 2012). To address endogeneity, we use Propensity Score (PSM). According to Li (2012), for example, a propensity score is defined as the probability of study participants receiving a treatment based on observed characteristics. PSM is a special procedure that uses propensity scores and a matching algorithm to calculate the causal effect. Shipman, Swanquist, \& Whited (2017) surveyed the use of PSM in accounting research and reported it has been used successfully to address many problems in accounting.

In this part of the study, we investigate the effects of the Sarbanes-Oxley Act (SOX), an exogenous shock that differently affected Financial and Non-financial firms. After the Enron scandal and subsequent collapse of Andersen, the U.S. Congress passed the Sarbanes-Oxley Act in July 2002.

This act requires that companies have better internal controls over financial reporting. Moreover, companies must evaluate these controls. Hence, we predict that after SOX, both Financial and Non-financial companies reduced their tax avoidance levels. The objective here is to analyze whether after passage of the Sarbanes-Oxley Act in 2002, the relatively higher pressure faced by firms prompted them to practice less tax avoidance. For this purpose, we use a dummy variable that is equal to 1 if the year is in the period from 2002 to 2018, and zero otherwise.

From the perspective of GAAP ETR, the Table 3.11 presents the results of the first-stage prediction model of Propensity Score Matching, probit regression. We can be seen that after SOX enactment, the likelihood of companies having greater GAAP ETR was negative. the measure of aggressive tax avoidance decreased by $10.80 \%$. Interestingly, financial companies became more aggressive in their tax avoidance. They increased the level of tax avoidance by $19.5 \%$ after the advent of SOX. 
Table 3.11 - First-stage prediction model of Propensity Score Matching (GAAP ETR)

\begin{tabular}{|c|c|}
\hline & (1) \\
\hline Variables & SOX \\
\hline \multirow[t]{2}{*}{ GAAP ETR } & $-0.108 * * *$ \\
\hline & {$[-0.010]$} \\
\hline \multirow[t]{2}{*}{ Finance } & $0.195 * * *$ \\
\hline & {$[0.021]$} \\
\hline \multirow[t]{2}{*}{$\mathrm{R} \& \mathrm{D}$} & -0.003 \\
\hline & {$[0.002]$} \\
\hline \multirow[t]{2}{*}{ Leverage } & $-0.634 * * *$ \\
\hline & {$[0.027]$} \\
\hline \multirow[t]{2}{*}{ Foreign Operations } & $0.224 * * *$ \\
\hline & {$[0.012]$} \\
\hline \multirow[t]{2}{*}{ Size } & $0.070 * * *$ \\
\hline & {$[0.025]$} \\
\hline \multirow[t]{2}{*}{ NOL } & $0.225 * * *$ \\
\hline & {$[0.010]$} \\
\hline \multirow[t]{2}{*}{ Intangibles } & $0.332 * * *$ \\
\hline & {$[0.029]$} \\
\hline \multirow[t]{2}{*}{ Gross PPE } & $0.167 * * *$ \\
\hline & {$[0.013]$} \\
\hline \multirow[t]{2}{*}{ ROA } & $-0.132 * * *$ \\
\hline & {$[0.020]$} \\
\hline \multirow[t]{2}{*}{ Market-to-Book } & $0.006 * * *$ \\
\hline & {$[0.007]$} \\
\hline \multirow[t]{2}{*}{ Constant } & $0.006 * * *$ \\
\hline & {$[0.007]$} \\
\hline Observations & 110,030 \\
\hline Year dummies & Yes \\
\hline Cluster Firm FE x Year & Yes \\
\hline Pseudo R-Squared & 0.0329 \\
\hline
\end{tabular}

Robust t-statistics in brackets $* * * \mathrm{p}<0.01, * * \mathrm{p}<0.05, * \mathrm{p}<0.10$

Table 3.12 presents the composition of the sample of PSM. Table 3.13 shows the PMS results by examining the effects of SOX on GAAP ETR of all companies of the sample. We performed the matching considering 1 neighbor, 5 neighbors and 10 neighbors. In all of them we 
found a negative result for the average treatment effect among the treated firms ATT. Consequently, it can be inferred that SOX forced listed American companies to engage in less aggressive tax avoidance.

Table 3.12 - Propensity Score Matching sample (GAAP ETR)

\begin{tabular}{llllll}
\hline & Obs & Mean & SD & Min & Max \\
\hline Full Sample & 110,030 & 0.8815 & 0.0503 & 0.5821 & 0.9967 \\
Sarbanes-Oxley Act (SOX) $=0$ & 13,038 & 0.8599 & 0.0537 & 0.5962 & 0.9936 \\
Sarbanes-Oxley Act (SOX) $=1$ & 96,992 & 0.8844 & 0.0492 & 0.5821 & 0.9967 \\
\hline
\end{tabular}


Table 3.13 - Matching - Sarbanes-Oxley Act (SOX): GAAP

ETR

\begin{tabular}{|c|c|c|c|c|c|c|c|c|c|}
\hline \multirow[b]{2}{*}{ Sample } & \multicolumn{3}{|c|}{$\begin{array}{c}\text { Nearest neighbor (1 neighbor) } \\
\text { with replacement }\end{array}$} & \multicolumn{3}{|c|}{$\begin{array}{c}\text { Nearest neighbor (5 neighbors) } \\
\text { with replacement }\end{array}$} & \multicolumn{3}{|c|}{$\begin{array}{c}\text { Nearest neighbor (10 neighbors) } \\
\text { with replacement }\end{array}$} \\
\hline & Treated & Difference & t-stat & Treated & Difference & t-stat & Treated & Difference & t-stat \\
\hline Unmatched & 0.1348 & -0.0352 & -7.26 & 0.1348 & -0.0352 & -7.26 & 0.1348 & -0.0352 & -7.26 \\
\hline ATT & 0.1348 & -0.0049 & -0.08 & 0.1348 & -0.0036 & -0.66 & 0.1348 & -0.003 & -0.57 \\
\hline $\mathrm{n}$ untreated & & & 13,038 & & & 13,038 & & & 13,038 \\
\hline $\mathrm{n}$ treated & & & 96,992 & & & 96,992 & & & 96,992 \\
\hline TOTAL & & & 110,030 & & & 110,030 & & & 110,030 \\
\hline
\end{tabular}


The Figure 3.1 shows the result of PSM GAAP ETR presents the results of the propensity score matching of the Sarbanes-Oxley Act (SOX) on tax avoidance. Here we use the proxy GAAP ETR.

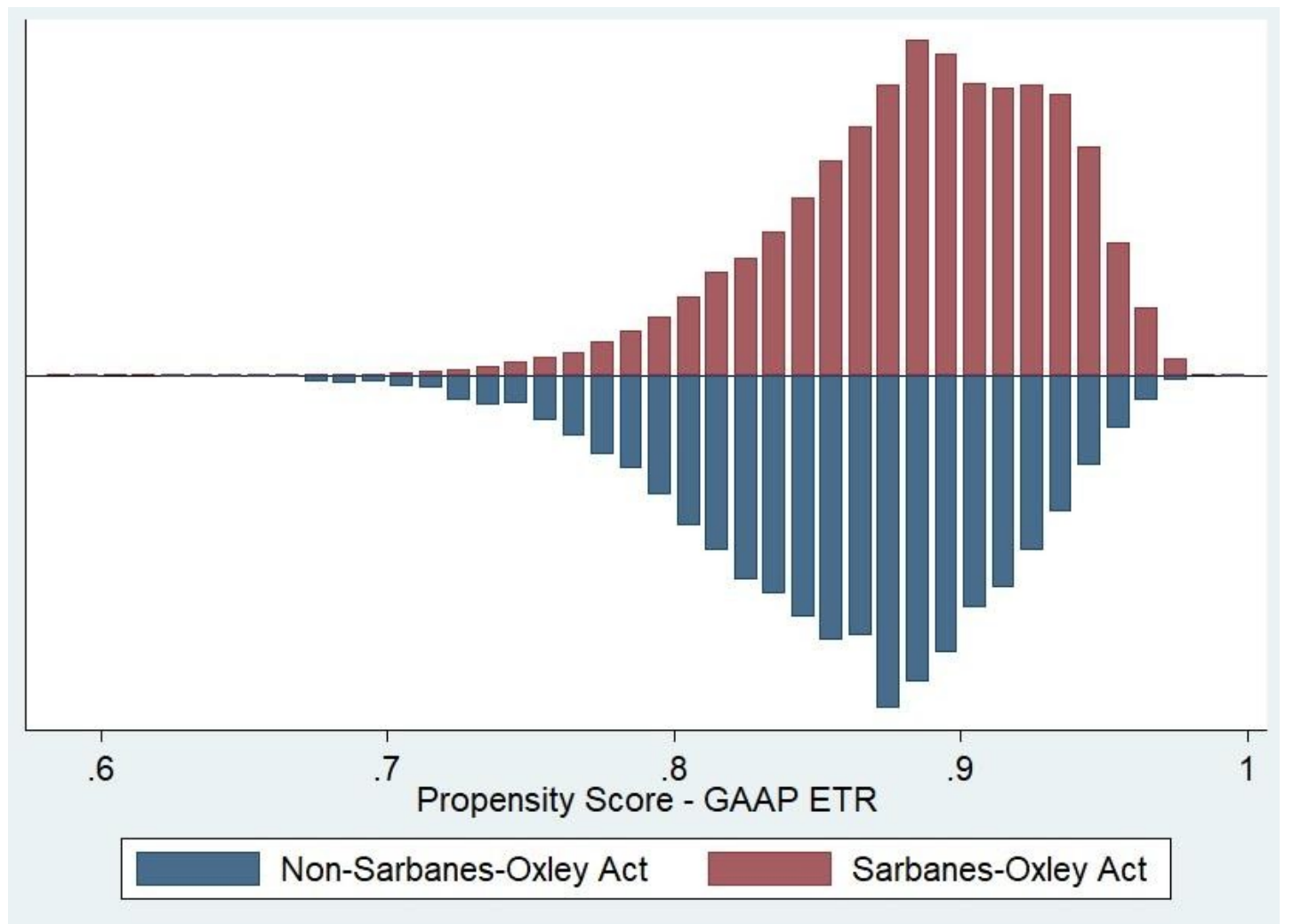

Figure 3.1 - Propensity score matching graph: Sarbanes-Oxley Act (SOX): GAAP ETR

Figure 3.2 exhibits the sample before matching. Here we use the proxy GAAP ETR. In turn, Figure 3.3 presents the sample after matching. Here we use the proxy GAAP ETR. 


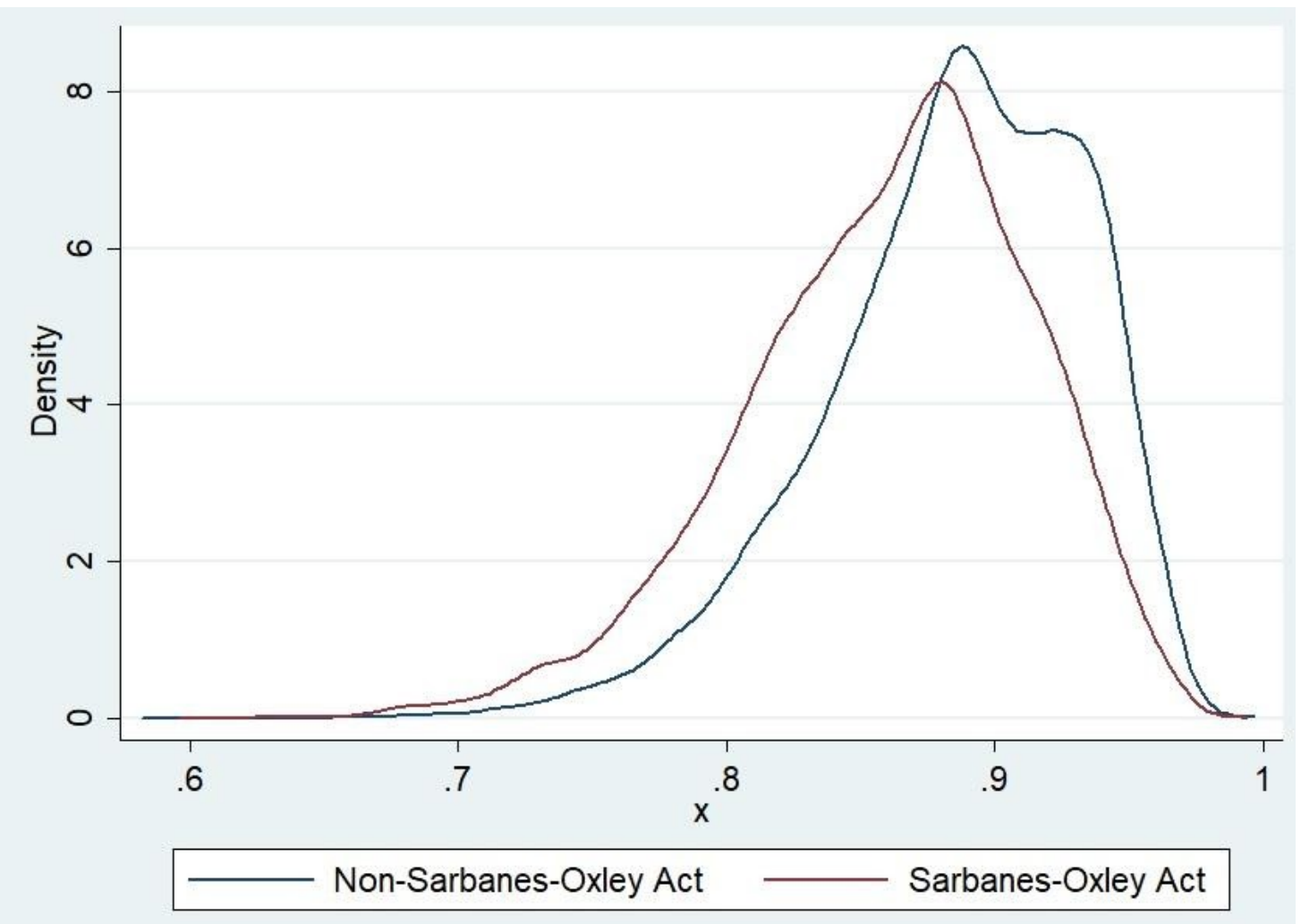

Figure 3.2 - Graph before matching: Sarbanes-Oxley Act (SOX): GAAP ETR

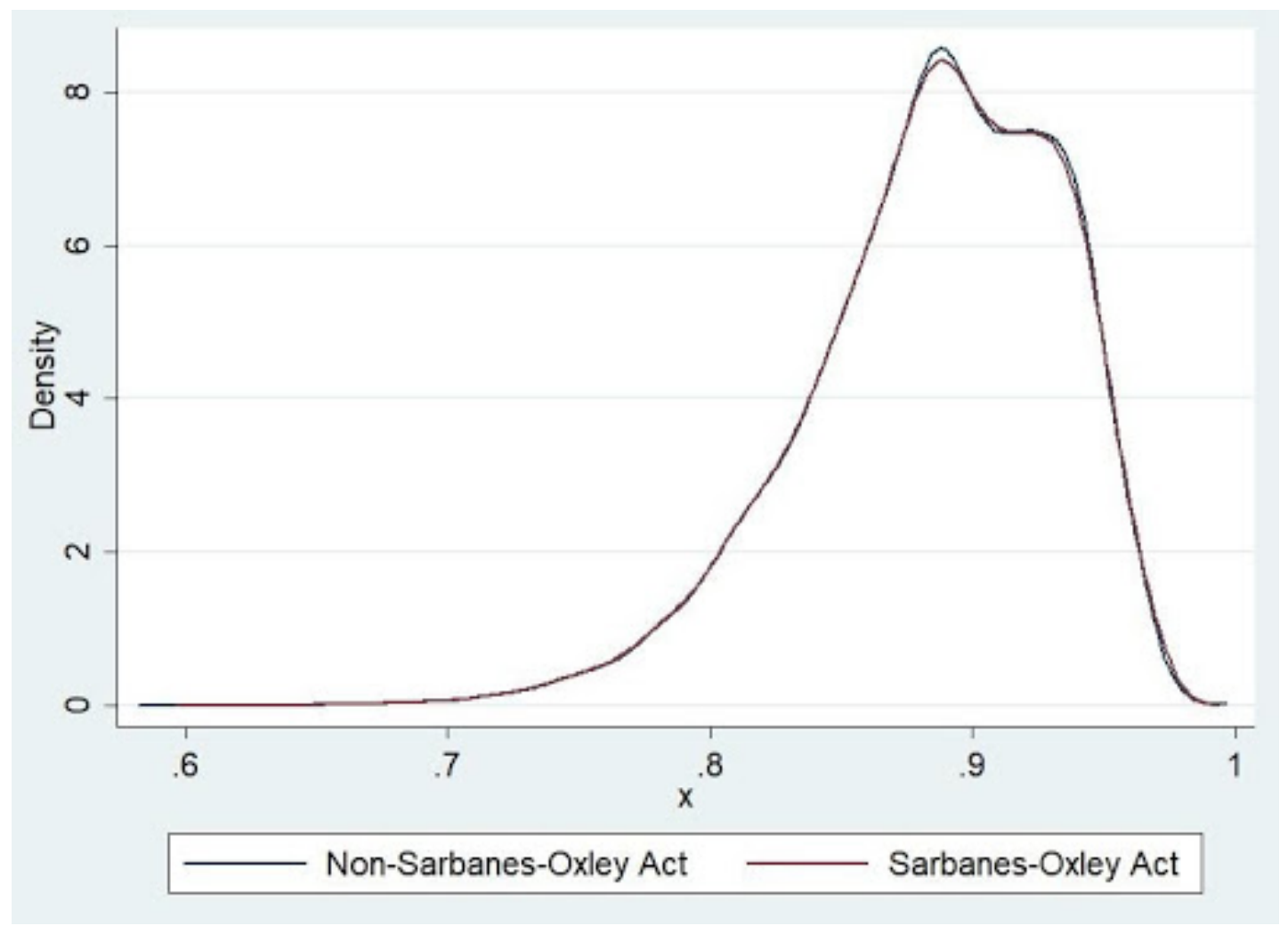

Figure 3.3 - Graph after matching: Sarbanes-Oxley Act (SOX): GAAP ETR

In contrast, from the perspective of CASH ETR, the Table 3.14 shows the results from the 
first-stage prediction model of the PSM regression. We find that with the SOX, public companies reduced by $10.50 \%$ the chance of practicing tax avoidance CASH ETR. However, we find that financial companies increased by $11.40 \%$ the chance of becoming more aggressive when practicing tax avoidance.

Table 3.14 - First-stage prediction model of Propensity Score Matching (CASH ETR)

\begin{tabular}{|c|c|}
\hline & $(2)$ \\
\hline Variables & SOX \\
\hline \multirow[t]{2}{*}{ CASH ETR } & $-0.105 * * *$ \\
\hline & {$[0.014]$} \\
\hline \multirow[t]{2}{*}{ Finance } & $0.114 * * *$ \\
\hline & {$[0.024]$} \\
\hline \multirow[t]{2}{*}{$\mathrm{R} \& \mathrm{D}$} & 0.001 \\
\hline & [0.005] \\
\hline \multirow[t]{2}{*}{ Leverage } & $-0.766 * * *$ \\
\hline & {$[0.031]$} \\
\hline \multirow[t]{2}{*}{ Foreign Operations } & $0.213 * * *$ \\
\hline & {$[0.013]$} \\
\hline \multirow[t]{2}{*}{ Size } & $0.087 * * *$ \\
\hline & {$[0.002]$} \\
\hline \multirow[t]{2}{*}{ NOL } & $0.190 * * *$ \\
\hline & {$[0.012]$} \\
\hline \multirow[t]{2}{*}{ Intangibles } & $0.490 * * *$ \\
\hline & {$[0.034]$} \\
\hline \multirow[t]{2}{*}{ Gross PPE } & $0.169 * * *$ \\
\hline & {$[0.015]$} \\
\hline \multirow[t]{2}{*}{ ROA } & $-0.205 * * *$ \\
\hline & {$[0.027]$} \\
\hline \multirow[t]{2}{*}{ Market-to-Book } & $0.010 * * *$ \\
\hline & {$[0.001]$} \\
\hline \multirow[t]{2}{*}{ Constant } & $0.480 * * *$ \\
\hline & {$[0.019]$} \\
\hline Observations & 86,803 \\
\hline Year dummies & Yes \\
\hline Cluster Firm FE x Year & Yes \\
\hline Pseudo R-Squared & 0.0410 \\
\hline
\end{tabular}

Robust t-statistics in brackets

$* * * \mathrm{p}<0.01, * * \mathrm{p}<0.05, * \mathrm{p}<0.10$ 
Table 3.15 presents the sample composition of PSM CASH ETR.

Table 3.15 - Sample of Propensity Score Matching (CASH ETR)

\begin{tabular}{llllll}
\hline & Obs & Mean & SD & Min & Max \\
\hline Full Sample & 86,803 & 0.8839 & 0.0557 & 0.5170 & 0.9997 \\
Sarbanes-Oxley Act (SOX) $=0$ & 10,078 & 0.857 & 0.0607 & 0.5808 & 0.9996 \\
Sarbanes-Oxley Act (SOX) $=1$ & 76,725 & 0.8874 & 0.0541 & 0.5170 & 0.9976 \\
\hline
\end{tabular}

Table 3.16 exhibits the results of matching in 1 neighbor, 5 neighbors and 10 neighbors. Curiously, we find in all of them a positive result for the average treatment effect among the treated $(A T T)$. Therefore, when analyzing tax avoidance practices from the perspective of $C A S H E T R$, we find that during the period SOX took effect, listed American companies had greater $C A S H E T R$. 
Table 3.16 - Matching - Sarbanes-Oxley Act (SOX): CASH

ETR

\begin{tabular}{|c|c|c|c|c|c|c|c|c|c|}
\hline \multirow[b]{2}{*}{ Sample } & \multicolumn{3}{|c|}{$\begin{array}{c}\text { Nearest neighbor (1 neighbor) } \\
\text { with replacement }\end{array}$} & \multicolumn{3}{|c|}{$\begin{array}{l}\text { Nearest neighbor (5 neighbors) } \\
\text { with replacement }\end{array}$} & \multicolumn{3}{|c|}{$\begin{array}{c}\text { Nearest neighbor (10 neighbors) } \\
\text { with replacement }\end{array}$} \\
\hline & Treated & Difference & t-stat & Treated & Difference & t-stat & Treated & Difference & t-stat \\
\hline Unmatched & 0.1388 & -0.009 & -2.27 & 0.1388 & -0.0090 & -2.27 & 0.1388 & -0.0090 & -2.27 \\
\hline ATT & 0.1388 & 0.0039 & 0.63 & 0.1388 & 0.0052 & 0.63 & & 0.0047 & 0.92 \\
\hline n untreated & & & 10,078 & & & 10,078 & & & 10,078 \\
\hline $\mathrm{n}$ treated & & & 76,725 & & & 76,725 & & & 76,725 \\
\hline TOTAL & & & 86,803 & & & 86,803 & & & 86,803 \\
\hline
\end{tabular}


Figure 3.4 presents the results of the propensity score matching of the Sarbanes-Oxley Act (SOX) on tax avoidance, using the proxy CASH ETR.

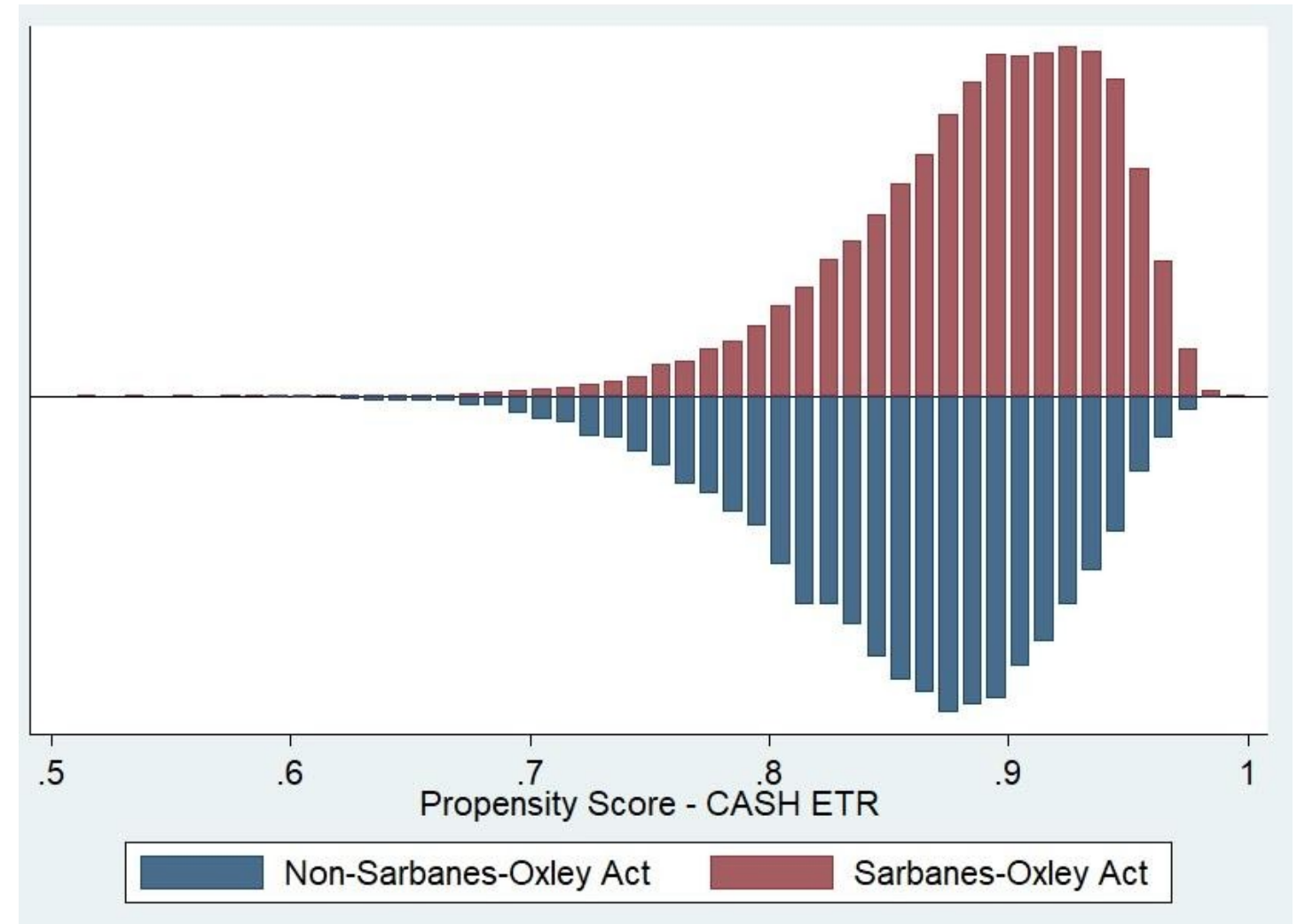

Figure 3.4 - Propensity score matching graph: Sarbanes-Oxley Act (SOX): CASH ETR

Figure 3.5 shows the sample before matching and Figure 3.6 exhibits the sample after matching. 


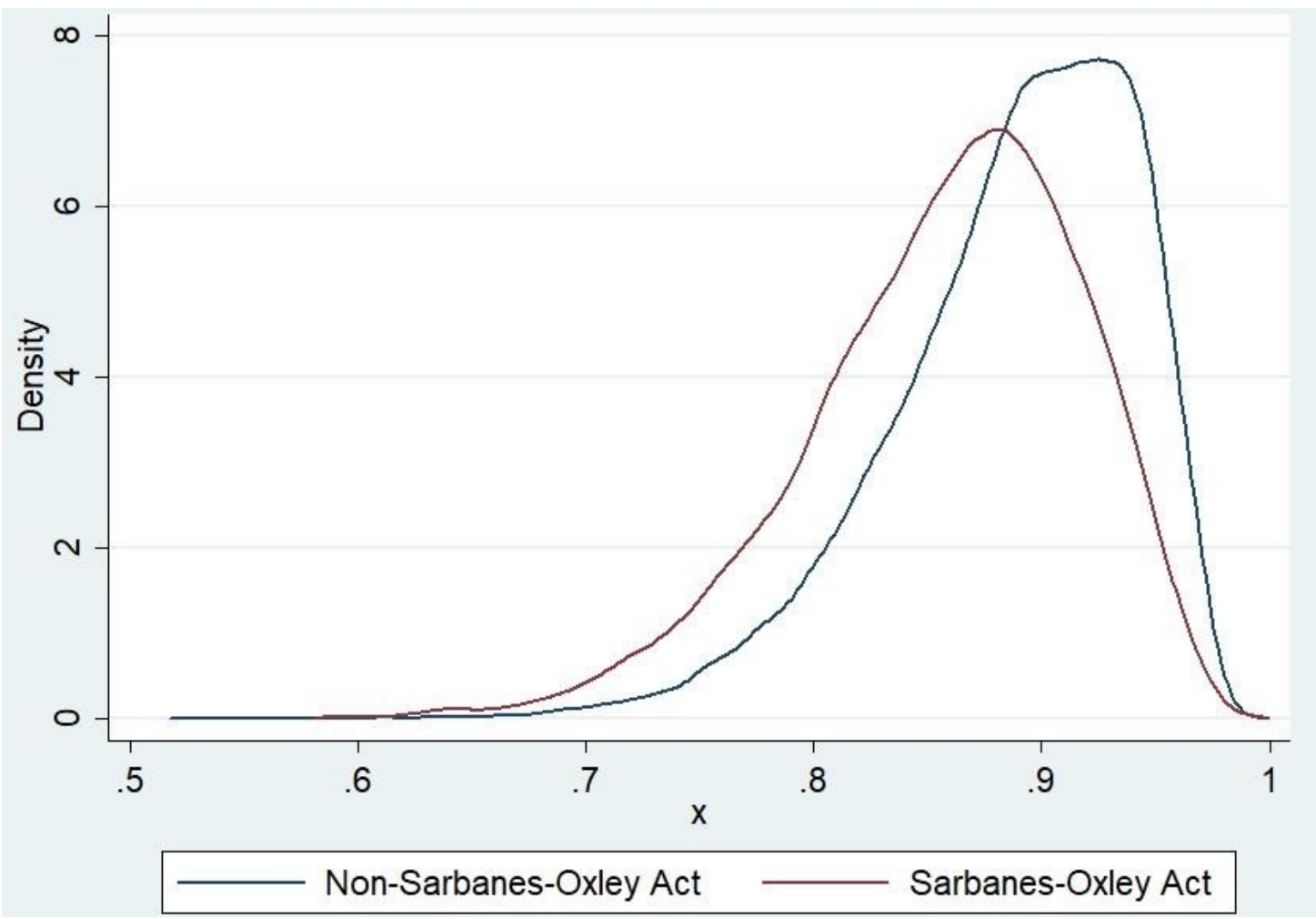

Figure 3.5 - Graph before matching: Sarbanes-Oxley Act (SOX): CASH ETR

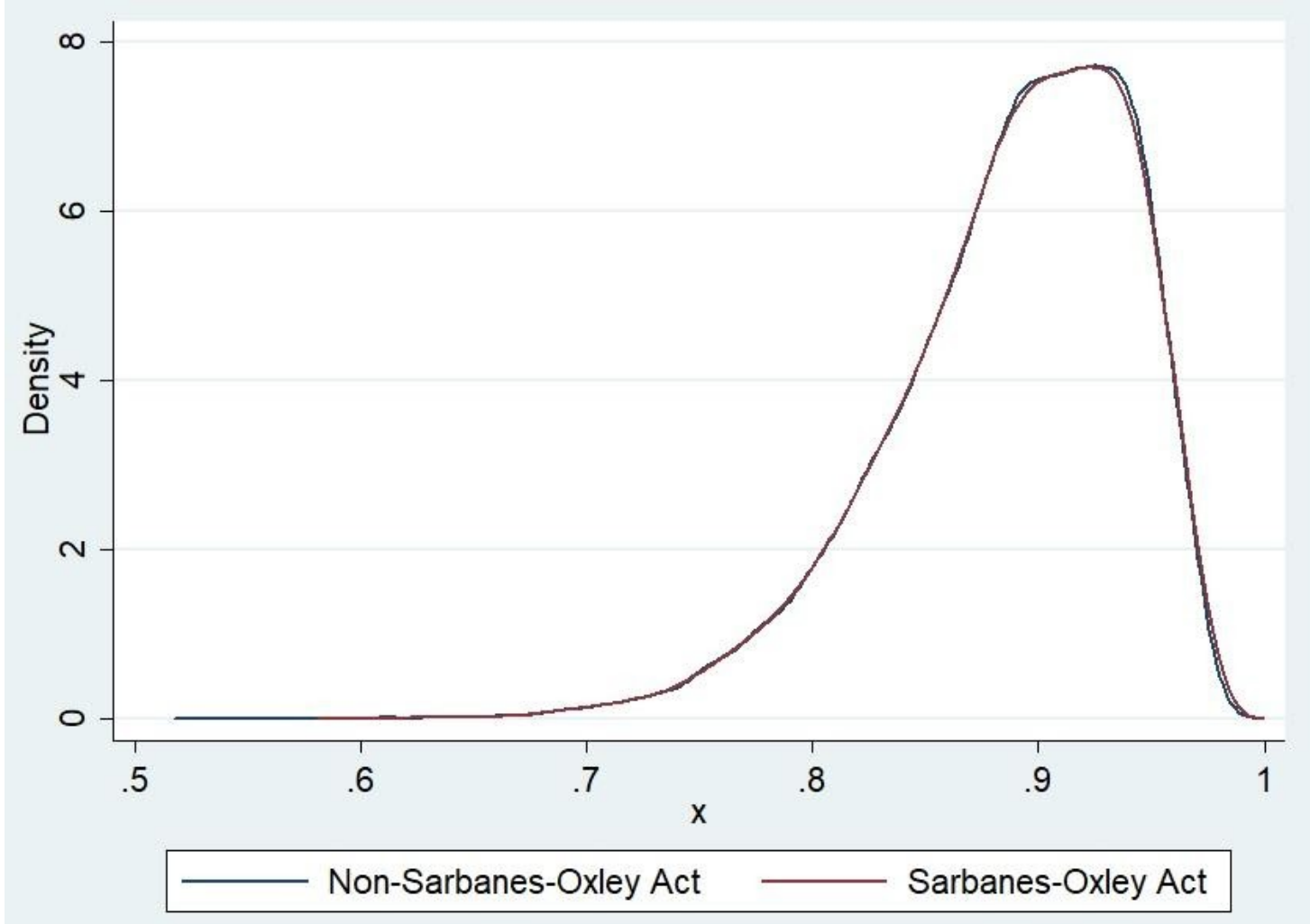

Figure 3.6 - Graph after matching: Sarbanes-Oxley Act (SOX): CASH ETR

The results presented in this part are a starting point to better understand the differences 
in the practice of tax avoidance between financial and non-financial companies. To date, we have not identified any other studies that have investigated. We encourage more empirical research to better understand whether financial companies practice less tax avoidance than companies in other sectors.

\subsection{Conclusion}

The results of this part of the study empirically confirm the first result of the theoretical model based on game theory by developing the propositions and lemmas in Section 2. The theoretical model shows that Banks are not more aggressive than Non-banks. This confirms the result that obtained from the theoretical analysis.

Therefore, in this part we examine whether financial companies practice less tax avoidance than companies from other sectors. For this purpose, we use two measures to capture tax avoidance (GAAP ETR and CASH ETR). The sample is composed by all U.S. public firms, with 110,030 firm-years in the Compustat database covering the period 2000-2018. We perform some methods to clarify this question. First, we perform regressions with robust standard errors, finding, that, statistically, there is no difference in the level of tax avoidance of financial companies in comparison with companies from other sectors. Economically, not having confirmed the research hypothesis that financial companies practice less tax avoidance than companies from other sectors implies that perhaps reputation costs have little effect on financial institutions' tax avoidance practices. It is possible that the effect of reputation costs does not directly affect financial companies. Therefore, its effect would be marginal.

In the quantile 0.10 , the group of the companies more aggressive when practicing tax avoidance, financial institutions pay more taxes, about $1.35 \%$ more in taxes. Therefore, in the group composed by companies more aggressive, financial institutions are less aggressive. However, in quantiles 0.50 and 0.90, they engage in less aggressive GAAP ETR than other companies. In the quantile 0.90 , the group of the companies less aggressive, financial institutions are more aggressive when practicing tax avoidance. They pay about $2.30 \%$ less taxes. Thus, as the level of GAAP ETR increases, financial institutions become more aggressive when practicing tax avoidance. From the perspective of CASH ETR, the results show that in the quantile 0.10 and 0.90 there is no statistical difference. However, we find that in the quantile 0.50 (median) financial institutions pay about $0.2 \%$ more taxes. Thus, they are less aggressive when practicing tax avoidance than non-financial institutions.

These results are important because they shed light on a problem not previously explored in the literature. Especially, because we find no difference about tax avoidance practices by using OLS method and panel data. However, when we use quantile regression, we can analyze the research question from other perspective and see how the GAAP ETR and CASH ETR variables vary over the quantiles. 
We also performed additional analysis to examine the effect of passage of the SarbanesOxley Act (SOX), an exogenous shock. Given that this law requires more responsibility, accountability and transparency, we expect it to have encouraged companies to be less aggressive tax avoidance. To examine this, we use Propensity Score Matching (PSM). From the view of GAAP ETR, we find in the probit regression that the level of GAAP ETR reduced the likelihood of public companies in the U.S. being more aggressive in terms of GAAP ETR by $10.80 \%$. However, when focusing on financial companies, we find higher likelihood being more aggressive when practicing tax avoidance by $19.50 \%$. The results of PSM show that in the period from 2002 to 2018 (after SOX enactment), the level of GAAP ETR decreased.

When performing PSM using the measure CASH ETR, we find curious results. In the first stage, we use probit regression and find that even though companies, in general, decreased the level of CASH ETR, financial companies presented a higher level of CASH ETR after the passage of SOX. When applying PSM, we find that the level of CASH ETR increased with the passage of SOX.

To date, we have not identified any other studies that analyzing whether the level of tax avoidance differs between financial and non-financial companies. This part of the study contributes to the literature in different ways. The main contribution of this study is that, unlike previous studies, we analyzed the entire population of publicly traded companies firms. Therefore, our study can be used to deepen the understanding of tax avoidance, mainly because this topic is rarely addressed in the literature. We suggest that more robust theoretical and empirical studies on tax avoidance on financial institutions can developed. We also contribute to the literature on tax avoidance and financial institutions and on the effects of the Sarbanes-Oxley Act of 2002. Finally, this study is a response to the call in Hanlon and Heitzman (2010) to study tax avoidance of financial institutions. 


\section{FINAL REMARKS}

In this section, we present the main conclusions derived from the outcomes of all two parts of this study.

In the first part, we developed a model based on game theory that considers the interplay of two types of taxpayers: Complex and Simple (Banks and Non-banks, respectively) and the IRS. This model enabled understanding the behavior of the IRS and taxpayers and the level of tax avoidance in equilibrium. The theoretical analysis was divided into two stages. In the first, we considered that the reputation costs of both groups were similar. We found that in equilibrium, banks are more aggressive practitioners of tax avoidance than non-banks. In the second stage, we considered that banks have higher reputation cost. We found not non-banks to be more aggressive. The comparative statistics showed that Complex taxpayers (banks) benefit when the fine increases. On the hand, they are sensitive to reputation cost. We proposed that a solution is to increase the reputation cost and fine simultaneously. The reputation cost can be increased by increasing the disclosure of tax avoidance cases.

In the second part, we empirically tested the result of the theoretical model with respect to banks' aggressiveness in practicing tax avoidance. For this purpose, we analyzed the data of U.S. public firms and found no difference in the level of tax avoidance of financial and non-financial firms during the period studied. However, when analyzing the date divided into quantiles, we found that in the 0.10 quantile, financial companies are more aggressive than other companies. Thus, the level of tax avoidance varies among the quantiles. Moreover, we concluded that the passage of the Sarbanes-Oxley Act (SOX) reduced the level of tax avoidance of all public companies in the United States.

The combination of theoretical and empirical approaches contributes to better understand how the IRS and financial and non-financial firms behave. 


\section{Bibliography}

Adelino, M., Gerardi, K., \& Hartman-Glaser, B. (2019). Are lemons sold first? Dynamic signaling in the mortgage market.Journal of Financial Economics, 132(1), 1-25.

Adrian, T., \& Shin, H. S. (2009). Federal Reserve Bank of New York Staff Reports The Shadow Banking System: Implications for Financial Regulation. Federal Reserve Bank of New York Staff Reports, (Staff Report no. 382), 1-18.

Akerlof, G. A. (1970). The Market for Lemons Quality Uncertainty and the Market Mechanism. The Quarterly Journal of Economics, 84(3), 488-500.

Allen, F., \& Michaely, R. (1995). Dividend policy. Handbooks in Operations Research and Management Science9, 793-837.

Allen, F., \& Faulhaber, G. R. (1989). Signalling by underpricing in the IPO market. Journal of Financial Economics23, 303-323.

Allingham, M. G., \& Sandmo, A. (1972). Income tax evasion: A theoretical analysis. Journal of Public Economics, 1, 323-338.

Armstrong, C. S., Blouin, J. L., Jagolinzer, A. D., \& Larcker, D. F. (2015). Corporate governance, incentives, and tax avoidance. Journal of Accounting and Economics, 60(1), 1-17.

Atwood, T. J., Drake, M. S., Myers, J. N., \& Myers, L. A. (2012). Home country tax system characteristics and corporate tax avoidance: International evidence. Accounting Review, 87(6), 1831-1860.

Barford, V., \& Holt, G. (2013). Google, Amazon, Starbucks: The rise of ?tax shaming?. BBC News Magazine

Baselga-Pascual, L., Trujillo-Ponce, A., Va“ha“maa, E., \& Va“ha“maa, S. (2018). Ethical Reputation of Financial Institutions: Do Board Characteristics Matter? Journal of Business Ethics, 148, 489-510.

Barth, J. R., Caprio, G. J., \& Levine, R. (2001). Banking Systems around the Globe: Do Regulation and Ownership Affect Performance and Stability? Prudential Supervision: What Works and What Doesn't, University of Chicago Press,31-96.

Barth, J. R., Caprio, G., \& Levine, R. (2004). Bank regulation and supervision: What works best? Journal of Financial Intermediation, 13(2), 205-248.

Beatty, A., \& Harris, D. G. (1998). The Effects of Taxes , Agency Costs and Information Asymmetry on Earnings Management: A Comparison of Public and Private Firms. Review of Accounting Studies, 3, 299-326. 
Bedendo, M., Cathcart, L., \& El-jahel, L. (2018). Reputational shocks and the information content of credit ratings. Journal of Financial Stability, 34, 44-60.

Beladi, H., Chur, C., \& Hu, M. (2018). International Review of Financial Analysis Does tax avoidance behavior affect bank loan contracts for Chinese listed firms? International Review of Financial Analysis, 58, 104-116.

Bender, B. (1984). A analysis of the Laffer curve. Economic Inquiry, 22(3), 414-420.

Bhattacharya, S., \& Thakor, A. V. (1993). Contemporary Banking Theory. Journal of Financial Intermediation, 3, 2-50.

Black, F. (1972). Capital Market Equilibrium with Restricted Borrowing. The Journal of Business, 45(3), 444-455.

Bozanic, Z., Hoopes, J. L., Thornock, J. R., \& Williams, B. M. (2017). IRS Attention. Journal of Accounting Research, 55(1), 79-114.

Blaufusa, K., Mohlmannb, A., Schwabea, A. N. (2019). Stock price reactions to news about corporate tax avoidance and evasion. Journal of Economic Psychology, 72(1) 278-292.

Blouin, J. (2014). Defining and Measuring Tax Planning Aggressiveness. National Tax Journal, 67(4), 875-900.

Bradley, M., Desai, A., \& Kim, E. H. (1988). Synergistic gains from corporate acquisitions and their division between the stockholders of target and acquiring firms. Journal of Financial Economics, 21, 3-40.

Brammer, S., Brooks, C., \& Pavelin, S. (2004). Corporate Reputation and Stock Returns: Are Good Firms Good for Investors? SSRN Electronic Journal, 1-21.

Brealey, R., Leland H. E., \& Pyle, D. H. (1977). Informational asymmetries, financial structure, and financial intermediation. The Journal of Finance, 32(2), 371-387

Brooks, C. (2008). Introductory econometrics for finance. Cambridge: Cambridge University Press.

Cameron, A. C., Trivedi, P. K. (2005). Microeconometrics: methods and applications. Cambridge: Cambridge University Press.

Carfi, D., \& Musolino, F. (2015). Tax evasion: A game countermeasure.AAPP Atti Della Accademia Peloritana Dei Pericolanti, Classe Di Scienze Fisiche, Matematiche e Naturali, 93(1), C2-1-C2-17.

Cen, L., Maydew, E. L., Zhang, L., \& Zuo, L. (2017). Customer-supplier relationships and corporate tax avoidance. Journal of Financial Economics, 123(2), 377-394. 
Chari, V., \& Jagannathan, R. (1988). Banking panics, information, and rational expectations equilibrium. Journal of Finance, 43, 749-760.

Chen, S., Chen, X., Cheng, Q., \& Shevlin, T. (2010). Are family firms more tax aggressive than non-family firms? Journal of Financial Economics, 95(1), 41-61.

Chen, K. P., \& Chu, C. Y. C. (2005). Internal control vs. external manipulation: A model of corporate income tax evasion. RAND Journal of Economics, 36(1), 151-164.

Chen, N. X., Chiu, P.-C., \& Shevlin, T. (2018). Do Analysts Matter for Corporate Tax Planning? Evidence from a Natural Experiment. Contemporary Accounting Research, 35(2), 794-829.

Chen, C., Zhao, Y., \& Zhao, Y. (2019). Corporate bond ratings, underwriters? reputation and cost of bonds. Asia-Pacific Journal of Accounting \& Economics, 26, 1-16.

Chen, S., Schuchard, K., \& Stomberg, B. (2019). Media coverage of corporate taxes. The Accounting Review, 94(5), 83-116.

Cho, I. K., M. \& Kreps, D. (1987). Signaling Games and Stable Equilibria. The Quarterly Journal of Economics, 102(2), 179-222.

Chyz, J. A, \& Gaertner, F. B. (2018). Can paying "too much" or "too little" tax contribute to forced CEO turnover? Accounting Review, 93(1), 103-130.

Chyz, J. A. (2013). Personally tax aggressive executives and corporate tax sheltering. Journal of Accounting and Economics, 56(2-3), 311-328.

Clemente, F., \& Lírio, V. S. (2018). Tax evasion in Brazil: the case of specialists. Journal of Economics Studies, 2, 401-410.

Connelly, B. L., Certo, S. T., Ireland, R. D., \& Reutzel, C. R. (2011). Signaling theory: A review and assessment. Journal of Management, 37(1), 39-67.

Coricelli, G., Rusconi, E., \& Villeval, M. C. (2014). Tax evasion and emotions: An empirical test of re-integrative shaming theory. Journal of Economic Psychology, 40, 49-61.

Crocker, K. J., \& Slemrod, J. (2005). Corporate tax evasion with agency costs. Journal of Public Economics, 89(9-10), 1593-1610.

Dalamagas, B. (2011). A dynamic approach to tax evasion. Public Finance Review, 39(2), 309-326.

Desai, M. A., \& Dharmapala, D. (2008a). Corporate tax avoidance and firm value. The Review of Economics and Statistics, 91(3), 537-546. 
Desai, M. A., \& Dharmapala, D. (2008b). Tax and Corporate Governance: An Economic Approach. MPI Studies on Intellectual Property, Competition and Tax Law, vol 3. Springer, Berlin, Heidelberg.

Dhaliwal, D. S., Goodman, T. H., Hoffman, P. J., \& Schwab, C. M. (2019). The Incidence, Valuation and Management of Tax-related Reputational Costs: Evidence from a Period of Protest. Working Paper, SSRN.

Diamond, D. W. (1984). Financial Intermediation and Delegated Monitoring. The Review of Economic Studies, 51(3), 393-414.

Diamond, D. W., \& Dybvig, P. H. (1983). Bank Runs, Deposit Insurance, and Liquidity. Journal of Political Economy, 91(3), 401-419.

Desai, M. A., Dyck, A., \& Zingales, L. (2007). Theft and taxes. Journal of Financial Economics, 84(3), 591-623.

Dhawan, R., \& Yu, F. (2015). Are Credit Ratings Relevant in China's Corporate Bond Market? Are Credit Ratings Relevant in China's Corporate Bond Market? The Chinese Economy, 48(3), 235-250.

Donohoe, M. (2015). Financial derivatives in corporate tax avoidance: A conceptual perspective. Journal of the American Taxation Association, 37(1): 37-68.

Dyreng, S. D., Hanlon, M., \& Maydew, E. L. (2008). Long-Run Corporate Tax Avoidance. The Accounting Review, 83(1), 61-82.

Dyreng, S. D., Hoopes, J. L., \& Wilde, J. H. (2015). Public Pressure and Corporate Tax Behavior. Journal of Accounting Research, 54(1), 147-185.

Engel, E., Hayres, R. M., \& Wang, X. (2007). The Sarbanes-Oxley Act and firms' going - private decisions. Journal of Accounting and Economics, 44, 116-145.

Fama, E., \& Babiak, H. (1968). Dividend policy: An empirical analysis. Journal of the American Statistical Association, 63, 1132-1161.

Fishman, M. J. (1988). A Theory of Preemptive Takeover Bidding. RAND Journal of Economics, 19(1), 88-101.

Frischmann, P. J., Shevlin, T., \& Wilson, R. (2008). Economic consequences of increasing the conformity in accounting for uncertain tax benefits. Journal of Accounting and Economics, 46(2-3), 261-278.

Gaertner, F. B. (2014). CEO After-Tax Compensation Incentives and Corporate Tax Avoidance. Contemporary Accounting Research, 31(4), 1077-1102. 
Georgescu, M., \& Jeflea, V. (2015). The Particularity of the Banking Information System. Procedia Economics and Finance, 20, 268-276.

Gordon, J. P. F. (1989). Individual morality and reputation costs as deterrents to tax evasion. European Economic Review, 33, 797-805.

Graetz, M. J., Reinganum, J. F., \& Wilde, L. L. (1986). The Tax Compliance Game: Toward an Interactive Theory of Law Enforcement. The Journal of Law, Economics, and Organization, 2(1), 1-32.

Graham, J. R., \& Tucker, A. L. (2006). Tax shelters and corporate debt policy. Journal of Financial Economics, 81(3), 563-594.

Greenberg, J. (1984). Avoiding tax avoidance: A (repeated) game-theoretic approach. Journal of Economic Theory, 32(1), 1-13.

Greene, W. H. (2011). Econometric analysis. Journal of Economic Theory, 32(1), 1-13.

Grossman, S. J., \& Hart, O. D. (1980). Takeover Bids , The Free-Rider Problem , and the Theory of the Corporation.The Bell Journal of Economics, 11(1), 42-64.

Gujarati, D., \& Porter, D. C. (2011). Econometria basica. 5. ed. Porto Alegre: Bookman.

Hanlon, M., \& Heitzman, S. (2010). A review of tax research. Journal of Accounting and Economics Economics, 50(2-3), 127-178.

Hanlon, M., \& Slemrod, J. (2009). What does tax aggressiveness signal? Evidence from stock price reactions to news about tax shelter involvement. Journal of Public Economics, 93, 126-141. Halperin, R., \& Lai, K. W. (2014). The relation between auditor-provided tax service fees and audit fees after the Sarbanes-Oxley Act: From the perspective of cross-selling of services. Journal of Accounting, Auditing \& Finance, 30(3), 341-372.

Hasan, I., Hoi, C. K. (Stan), Wu, Q., \& Zhang, H. (2014). Beauty is in the eye of the beholder: The effect of corporate tax avoidance on the cost of bank loans. Journal of Financial Economics, 113(1), 109-130.

Hamilton, B. H., \& Nickerson, J. A. (2003). Correcting for endogeneity in strategic management research. Strategic Organization, 1, 51-78.

Harris, M., \& Raviv, A. (1991). The Theory of Capital Structure. The Journal of Finance, 46(1), 297-355.

Harsanyi, J. C. (1967). Games with Incomplete Information Played by "Bayesian" Players, I-III Part I. The Basic Model. Management Science, 14(3), 159-182. 
Hirshleifer, D. (1995). Mergers and acquisitions: Strategic and informational issues. Handbooks in Operations Research and Management Science, 839-885.

Hoi, C. K., Wu, Q., \& Zhang, H. (2013). Is corporate social responsibility (CSR) associated with tax avoidance? Evidence from irresponsible CSR activities. The Accounting Review, 88(6), 2025-2059.

Holt, C. A., \& Laury, S. K. (2002). Risk Aversion and Incentive Effects. The American Economic Review, 92(5), 1644-1655.

Khan, M., Srinivasan, S., \& Tan, L. (2017). Institutional ownership and corporate tax avoidance: New evidence. The Accounting Review, 92(2), 101-122.

Kim, J. B., Song, B. Y., \& Zhang, L. (2011). Internal control weekness and bank loan contracting: Evidence from SOX section 404 disclosures. The Accounting Review, 86(4), 1157-1188.

Koenker, R., Bassett, G., \& Jan, N. (2007). Regression Quantiles. Econometrica, 46(1), 33-50.

Ibbotson, R., \& Ritter, J. (1995). Initial public offerings. Handbooks in Operations Research and Management Science, 993-1016.

Jennings, R. H., \& Mazzeo, M. A. (1993). Competing Bids, Target Management Resistance, and the Structure of Takeover Bids. The Review of Financial Studies, 6(4), 883-909.

Li, M. (2012). Using the Propensity Score Method to Estimate Causal Effects: A Review and Practical Guide. Organizational Research Methods, 1-39.

Lintner J. (1956). Distribution of Incomes of Corporations Among Dividends, Retained Earnings, and Taxes.The American Economic Review, 46(2), 97-113.

Lipatov, V. (2012). Corporate tax evasion: The case for specialists. Journal of Economic Behavior Organization, 81(1), 185-206.

Litina, A., \& Palivos, T. (2016). Corruption, tax evasion and social values.Journal of Economic Behavior and Organization, 124, 164-177.

Logue, D. (1973). On the Pricing of Unseasoned Equity Issues: 1965-1969.Journal of Financial and Quantitative Analysis, 8, 91-103.

Manne, H. (1965). Mergers and the market for corporate control. Journal of Political Economy, $73,110-120$.

Milde, H., \& Riley, J. G. (1988). Signaling in Credit Markets. The Quarterly Journal of Economics, 103(1), 101-129.

Minnick, K., \& Noga, T. (2010). Do corporate governance characteristics influence tax management? Journal of Corporate Finance, 16(5), 703-718. 
Mitzkewitz, M., Nagel, R. (1993). Experimental results on ultimatum games with incomplete information. International Journal of Game Theory, 22(2), 171-198.

Morris, R. D. (1987). Signalling, Agency Theory and Accounting Policy Choice. Accounting and Business Research, 18(69), 47-69.

Myers, S. C. (1984). The Capital Structure Puzzle. The Journal of Finance, XXXIX(3), 575-592. Myers, S. C., Majluf, N. S. (1984). Corporate financing and investment decisions when firms have information that investors do not have. Journal of Financial Economics, 13(2), 187-221.

Nachbar, J. H. (2001). Bayesian learning in repeated games of incomplete information. Social Choice and Welfare, 18(2), 303-326.

Petersen, M. A. (2009). Estimating Standard Errors In Finance Panel Data Sets: Comparing Approaches. The Review of Financial Studies, 22(1), 435-480.

Plumley, A. H. (1996). The Determinants of Individual Income Tax Compliance: Estimating the Impacts of Tax Policy, Enforcement and IRS Responsiveness. Internal Revenue Service Publication, 1-90.

Raskolnikov, A. (2011). Statement before the Joint Hearing of the U.S. House Committee on Ways and Means and U.S. Senate Committee on Finance. Tax Reform and the Tax Treatment of Financial Product (December 6).

Tax-Avoidance Activities of U.S. Multinational Corporations. Contemporary Accounting Research, 20(4), 805-833.

Rego, S. O. (2003). Tax-Avoidance Activities of U.S. Multinational Corporations. Contemporary Accounting Research, 20(4), 805-833.

Rego, S. O., \& Wilson, R. (2012). Equity Risk Incentives and Corporate Tax Aggressiveness. Journal of Accounting Research, 50(3), 775-810.

Ritsema, C. M., Thomas, D. W., Ferrier, G. D. (2003). Economic and Behavioral Determinants of Tax Compliance: Evidence from the 1997 Arkansas Tax Penalty Amnesty Program. IRS Research Conference, 1-25.

Rock, K. (1986). Why new issues are underpriced. Journal of Financial Economics, 15, 187-212.

Ross, S. A. (1977). The Determination of Financial Structure: The Incentive-Signalling Approach. The Bell Journal of Economics, 8(1), 23-40.

Ruud, J. S. (1993). Underwriter price support and the IPO underpricing puzzle. Journal of Financial Economics, 34, 135-151. 
Samuelson, L. (2016). Game theory in economics and beyond. Journal of Economic Perspectives, 30(4), 107-130.

Shackelford and Shevlin. (2001). Empirical tax research in accounting: A discussion. Journal of Accounting and Economics, 31(1-3), 389-403.

Slemrod, J. (2004). The Economics of Corporate Tax Selfishness. National Tax Journal, 57(4), 877-899.

Shipman, J. E., Swanquist, Q. T., \& Whited, R. L. (2017). Propensity Score Matching in Accounting Research. The Accounting Review, 92(1), 213-244.

Sloof, R., Winden, F. Van. (2000). A Game-Theoretic Analysis of Lobbying and Pressure. Public Choice, 104(1), 81-120.

Spence, M. (1973). Job Market Signaling. The Quarterly Journal of Economics, 87(3), 355-374.

Stiglitz, J. E., Weiss, A. (1981). Credit Rationing in Markets with Imperfect Information. American Economic Association, 71(3), 393-410.

Taleb, N. N., \& Sandis, C. (2014). The Skin In The Game Heuristic for Protection Against Tail Events. Review of Behavioral Economics, 1, 115-135.

Thakor, A. V. (1996). The design of financial systems: An overview. Journal of Banking Finance, 20, 917-948.

Thompson, S. B. (2011). Simple formulas for standard errors that cluster by both firm and time. Journal of Financial Economics, 99(1), 1-10.

Wilson, R. J. (2009). An Examination of Corporate Tax Shelter Participants. The Accounting Review, 84(3), 969-999.

Wooldridge, J. M. (2010). Econometric analysis of cross section and panel data. 2 nd ed. Cambridge: Mit Press.

Zimmerman, J. (1983). Taxes and Firm size. Journal of Accounting Economics, 5, 119-149. 
Appendices 


\section{Methodological procedures}

\section{Section 3 - Methodological procedures (Do-file / Stata)}

disp "Have a great day!"

$* *$

$/ /$ To create a document with the programming

cd "G: $\backslash$ Meu Drive $\backslash$ Doutorado ATUAL $\backslash$ Tese atual $\backslash 2$ - Do financial institutions practice more tax avoidance $\backslash$ Paper 02 - Tax avoidance Banks x Non-banks $\backslash$ Base de dados"

log using Banks-NonBanks.txt, text replace

$* *$

//To import database

use "G: $\backslash$ Meu Drive $\backslash$ Doutorado ATUAL $\backslash$ Tese atual $\backslash 2$ - Do financial institutions practice more tax avoidance $\backslash$ Paper 02 - Tax avoidance Banks x Non-banks $\backslash$ Base de dados $\backslash$ Base.dta", clear

**Solving problem of variables that are number and have been imported as text destring gvkey datadate fyear indfmt consol popsrc datafmt conm curcd fyr at ceq csho dlc dltt intan oibdp pi pifo, replace

destring ppegt sale spi tlcf txpd txt xad xrd costat prec_f naics, replace

**CALCULATE THE VARIABLES //Replace Total Assets < 1

replace at $=$. if at $<1$

//GAAP ETR

gen gaap_etr=txt/(pi-spi)

//CASH ETR

gen cash_etr $=\operatorname{txpd} /($ pi- spi)

//Size

gen size $=\ln ($ at $)$

//Leverage

gen leverage $=(\mathrm{dltt}+\mathrm{dlc}) / \mathrm{at}$

$/ / R \& D$

gen r_and_d=xrd/ sale

replace $r \_$and_d $=0$ if $r \_$and_d $==$.

//Advertsing

gen advertising $=\mathrm{xad} / \mathrm{sale}$

//Foreign operations

gen foreign_operations=1 if pifo!=. replace foreign_operations=0 if foreign_operations==. 
//NOL (Net Operating Loss)

gen nol $=1$ if tlcf $!=$. replace nol $=0$ if nol==.

//Intangibles to total assets

gen intangibles $=$ intan $/$ at

//Gross PP\&E to total assets

gen gross_ppe $=$ ppegt $/$ at

//ROA

gen roa $=$ oibdp $/$ at

//Market-to-Book

gen market_to_book $=($ prcc_f $*$ csho $) /$ ceq

replace market_to_book $=$. if market_to_book $<=0$

**//Clearing Base Missings

drop if gaap_etr==.

drop if size $==$.

drop if leverage $==$.

drop if r_and_d==.

drop if foreign_operations==.

drop if nol==.

drop if intangibles $==$.

drop if gross_ppe==.

drop if roa==.

drop if market_to_book==.

** //Treatment of outliers - Winsorized the variables at leve 1\% and 99\%

winsor2 gaap_etr, cuts(1 99) by(fyr)

winsor2 cash_etr, cuts(199) by(fyr)

winsor2 r_and_d, cuts(1 99) by(fyr)

winsor2 advertising, cuts(1 99) by(fyr)

winsor2 leverage, cuts(1 99) by(fyr)

winsor2 foreign_operations, cuts(1 99) by(fyr)

winsor2 size, cuts(1 99) by(fyr)

winsor2 nol, cuts(1 99) by(fyr)

winsor2 intangibles, cuts(1 99) by(fyr)

winsor2 gross_ppe, cuts(1 99) by(fyr)

winsor2 roa, cuts(1 99) by(fyr)

winsor2 market_to_book, cuts(1 99) by(fyr)

**//Dummies by sectors 
tostring naics, replace

generate agriculture $=0$

replace agriculture $=1$ if $\operatorname{substr}($ naics, 1,2$)==$ " $11 "$

generate mining $=0$

replace mining $=1$ if $\operatorname{substr}($ naics, 1,2$)==$ " 21 "

generate utilities $=0$

replace utilities $=1$ if $\operatorname{substr}($ naics, 1,2$)==" 22 "$

generate construction $=0$

replace construction $=1$ if $\operatorname{substr}($ naics, 1,2$)==$ " 23 "

generate manufacturing_31 $=0$

replace manufacturing_ $31=1$ if $\operatorname{substr}($ naics, 1,2$)==$ "31"

generate manufacturing_32 $=0$

replace manufacturing_32 $=1$ if $\operatorname{substr(naics,~1,2)==~"32"~}$

generate manufacturing_33 $=0$

replace manufacturing_33 $=1$ if $\operatorname{substr}($ naics, 1,2$)==" 33 "$

generate wholesale $=0$

replace wholesale $=1$ if $\operatorname{substr}($ naics, 1,2$)==" 42 "$

generate retail_44 $=0$

replace retail_ $44=1$ if $\operatorname{substr}($ naics, 1,2$)==" 44 "$

generate retail $\_5=0$

replace retail_45 $=1$ if substr(naics, 1,2$)==" 45 "$

generate transportation_48 $=0$

replace transportation_48 $=1$ if $\operatorname{substr}($ naics, 1,2$)==" 48 "$

generate transportation_49 $=0$

replace transportation_49=1 if substr(naics, 1, 2) == "49"

generate information $=0$

replace information $=1$ if $\operatorname{substr}($ naics, 1,2$)==" 51 "$

generate finance $=0$

replace finance $=1$ if $\operatorname{substr}($ naics, 1,2$)==" 52 "$

generate real $=0$

replace real = 1 if $\operatorname{substr}($ naics, 1,2$)==" 53 "$

generate professional $=0$

replace professional $=1$ if $\operatorname{substr}($ naics, 1,2$)==" 54 "$ 
generate management $=0$

replace management $=1$ if $\operatorname{substr}($ naics, 1,2$)==" 55 "$

generate administrative $=0$

replace administrative $=1$ if $\operatorname{substr}($ naics, 1,2$)==" 56 "$

generate educational $=0$

replace educational $=1$ if $\operatorname{substr}($ naics, 1,2$)==" 61 "$

generate health $=0$

replace health $=1$ if $\operatorname{substr}($ naics, 1,2$)==" 62 "$

generate arts $=0$

replace arts = 1 if substr(naics, 1,2$)==" 71 "$

generate accommodation $=0$

replace accommodation $=1$ if substr(naics, 1,2$)==" 72 "$

generate other $\_81=0$

replace other_81 = 1 if $\operatorname{substr}($ naics, 1,2$)==" 81 "$

generate other_99 $=0$

replace other_99 = 1 if $\operatorname{substr}($ naics, 1, 2) == "99"

generate public $=0$

replace public $=1$ if $\operatorname{substr}($ naics, 1,2$)==" 92 "$

$* *$

//Sample by NAICS Industry

tab agriculture

tab mining

tab utilities

tab construction

tab manufacturing_31

tab manufacturing_32

tab manufacturing_33

tab wholesale

tab retail_44

tab retail_45

tab transportation_48

tab transportation_49

tab information

tab finance

tab real

tab professional 
tab management

tab administrative

tab educational

tab health

tab arts

tab accommodation

tab other_81

tab other_99

tab public

$* *$

//Dummies of years

tab fyear

gen year_2000 $=1$ if fyear $==2000$

replace year_2000 $=0$ if year_2000==.

gen year_2001 $=1$ if fyear $==2001$

replace year_2001=0 if year_2001==.

gen year $\_2002=1$ if fyear $==2002$

replace year_2002 $=0$ if year_2002==.

gen year_2003 $=1$ if fyear $==2003$ replace year_2003=0 if year_2003==.

gen year_2004=1 if fyear==2004

replace year_2004=0 if year_2004==.

gen year_2005 $=1$ if fyear $==2005$

replace year_2005=0 if year_2005==.

gen year_2006 $=1$ if fyear==2006

replace year_2006 $=0$ if year_2006 $==$.

gen year_2007=1 if fyear $==2007$

replace year_2007=0 if year_2007==.

gen year_2008 $=1$ if fyear $==2008$

replace year_2008 $=0$ if year_2008==.

gen year_2009=1 if fyear==2009

replace year_2009=0 if year_2009==.

gen year_2010 $=1$ if fyear $==2010$

replace year_2010=0 if year_2010==.

gen year_2011=1 if fyear==2011 
replace year_2011=0 if year_2011==.

gen year_2012 $=1$ if fyear $==2012$

replace year_2012=0 if year_2012==.

gen year_2013=1 if fyear $==2013$

replace year_2013=0 if year_2013==.

gen year_2014=1 if fyear==2014

replace year_2014=0 if year_2014==.

gen year_2015 $=1$ if fyear $==2015$

replace year_2015=0 if year_2015==.

gen year_2016 $=1$ if fyear $==2016$

replace year_2016=0 if year_2016==.

gen year_2017 $=1$ if fyear $==2017$

replace year_2017=0 if year_2017==.

gen year_2018 $=1$ if fyear $==2018$

replace year_2018=0 if year_2018==.

$* *$

//Sample by years Bank x Non-Bank

tab fyear finance

$* *$

//Knowing the data

codebook gaap_etr_w

codebook cash_etr_w

codebook r_and_d_w

codebook advertising_w

codebook leverage_w

codebook foreign_operations_w

codebook size_w

codebook nol_w

codebook intangibles_w

codebook gross_ppe_w

codebook roa_w

codebook market_to_book_w

$* *$

//Summarize all variables ((Median)

summarize gaap_etr_w cash_etr_w finance r_and_d_w leverage_w foreign_operations_w size_w nol_w 
intangibles_w gross_ppe_w roa_w market_to_book_w

summarize gaap_etr_w cash_etr_w finance r_and_d_w leverage_w foreign_operations_w size_w nol_w

intangibles_w gross_ppe_w roa_w market_to_book_w, detail

$* *$

//Summarize all variables by Bank (Median)

summarize gaap_etr_w if finance $==1$, detail

summarize cash_etr_w if finance==1, detail

summarize r_and_d_w if finance $==1$, detail

summarize advertising_w if finance $==1$, detail

summarize leverage_w if finance $==1$, detail

summarize foreign_operations_w if finance $==1$, detail

summarize size_w if finance $==1$, detail

summarize nol_w if finance $==1$, detail

summarize intangibles_w if finance $==1$, detail

summarize gross_ppe_w if finance $==1$, detail

summarize roa_w if finance $==1$, detail

summarize market_to_book_w if finance $==1$, detail

$* *$

//Summarize all variables by Non-Bank (Median)

summarize gaap_etr_w if finance $==0$, detail

summarize cash_etr_w if finance $==0$, detail

summarize r_and_d_w if finance $==0$, detail

summarize advertising_w if finance $==0$, detail

summarize leverage_w if finance $==0$, detail

summarize foreign_operations_w if finance $==0$, detail

summarize size_w if finance $==0$, detail

summarize nol_w if finance $==0$, detail

summarize intangibles_w if finance $==0$, detail

summarize gross_ppe_w if finance $==0$, detail

summarize roa_w if finance $==0$, detail

summarize market_to_book_w if finance $==0$, detail

$* *$

//Test of difference of means

ttest gaap_etr_w, by (finance)

ttest cash_etr_w, by (finance)

ttest r_and_d_w, by (finance)

ttest advertising_w, by (finance) 
ttest leverage_w, by (finance)

ttest foreign_operations_w, by (finance)

ttest size_w, by (finance)

ttest nol_w, by (finance)

ttest intangibles_w, by (finance)

ttest gross_ppe_w, by (finance)

ttest roa_w, by (finance)

ttest market_to_book_w, by (finance)

$* *$

//Spearman's correlation

spearman gaap_etr_w cash_etr_w finance r_and_d_w leverage_w foreign_operations_w size_w nol_w

intangibles_w gross_ppe_w roa_w market_to_book_w, star (.05)

$* *$

//Pearson's correlation

pwcorr gaap_etr_w cash_etr_w finance r_and_d_w leverage_w foreign_operations_w size_w nol_w

intangibles_w gross_ppe_w roa_w market_to_book_w, star (.05)

//REGRESSION OLS **

//Regression - GAAP ETR

reg gaap_etr_w finance r_and_d_w leverage_w foreign_operations_w size_w nol_w intangibles_w gross_ppe_w

roa_w market_to_book_w

$* *$

//Regression - CASH ETR

reg cash_etr_w finance r_and_d_w leverage_w foreign_operations_w size_w nol_w intangibles_w gross_ppe_w roa_w market_to_book_w

**//PANEL REGRESSION

*Defining painel* xtset gvkey fyear

**GAAP ETR REGRESSION**

**Fixed Effects**

xtreg gaap_etr_w finance r_and_d_w leverage_w foreign_operations_w size_w nol_w intangibles_w gross_ppe_w

roa_w market_to_book_w, fe

estimates store fe 
**Random Effects**

xtreg gaap_etr_w finance r_and_d_w leverage_w foreign_operations_w size_w nol_w intangibles_w gross_ppe_w

roa_w market_to_book_w, re

estimates store re

**Testing which is the best model**

hausman fe re

**Testing heteroskedasticity** xtreg gaap_etr_w finance r_and_d_w leverage_w foreign_operations_w

size_w nol_w intangibles_w gross_ppe_w

roa_w market_to_book_w

*Wooldridge test for autocorrelation**

findit xtserial

xtserial gaap_etr_w finance r_and_d_w leverage_w foreign_operations_w size_w nol_w intangi-

bles_w gross_ppe_w

roa_w market_to_book_w

*Random Effects**

xtreg gaap_etr_w finance r_and_d_w leverage_w foreign_operations_w size_w nol_w intangibles_w gross_ppe_w

roa_w market_to_book_w, re

**CASH ETR REGRESSION**

**Fixed Effects** $x$ treg cash_etr_w finance r_and_d_w leverage_w foreign_operations_w size_w nol_w intangibles_w gross_ppe_w roa_w market_to_book_w, fe

estimates store FE

**Random Effects**

xtreg cash_etr_w finance r_and_d_w leverage_w foreign_operations_w size_w nol_w intangibles_w gross_ppe_w roa_w market_to_book_w, re

estimates store re

**Testing which is the best model** hausman fe re

**Testing heteroskedasticity** xtreg cash_etr_w finance r_and_d_w leverage_w foreign_operations_w size_w nol_w intangibles_w gross_ppe_w roa_w market_to_book_w, rob xttest0

**Wooldridge test for autocorrelation**

findit xtserial

xtserial cash_etr_w finance r_and_d_w leverage_w foreign_operations_w size_w nol_w intangi- 
bles_w gross_ppe_w roa_w market_to_book_w

*OLS x Random Effects**

**GAAP ETR** reg gaap_etr_w finance r_and_d_w leverage_w foreign_operations_w size_w nol_w intangibles_w gross_ppe_w

roa_w market_to_book_w, robust outreg2 using myreg_gaap.doc, replace ctitle(OLS)

xtreg gaap_etr_w finance r_and_d_w leverage_w foreign_operations_w size_w nol_w intangibles_w gross_ppe_w

roa_w market_to_book_w, re robust outreg2 using myreg_gaap.doc, append ctitle(Random Effects) addtext(Year dummies, Yes)

\section{$* *$ CASH ETR**}

reg cash_etr_w finance r_and_d_w leverage_w foreign_operations_w size_w nol_w intangibles_w gross_ppe_w roa_w market_to_book_w, robust outreg2 using myreg_cash.doc, replace ctitle(OLS)

xtreg cash_etr_w finance r_and_d_w leverage_w foreign_operations_w size_w nol_w intangibles_w gross_ppe_w roa_w market_to_book_w, re robust outreg2 using myreg_cash.doc, append ctitle(Random Effects) addtext(Year dummies, Yes)

** //Regression Quantile

sqreg gaap_etr_w finance r_and_d_w leverage_w foreign_operations_w size_w nol_w intangibles_w gross_ppe_w roa_w market_to_book_w, quantiles(10 50 90) reps(20)

sqreg cash_etr_w finance r_and_d_w leverage_w foreign_operations_w size_w nol_w intangibles_w gross_ppe_w roa_w market_to_book_w, quantiles(10 50 90) reps(20)

$* *$

//Propensity Score Matching - GAAP ETR (Sarbanes Oxley Act)

gen TREAT $=0$

replace TREAT $=1$ if fyear==2002 | fyear==2003 | fyear==2004 | fyear==2005 | fyear==2006 | fyear==2007 | fyear==2008 | fyear==2009 | fyear==2010 | fyear==2011 | fyear==2012 | fyear==2013 | fyear==2014 | fyear==2015 | fyear==2016 | fyear==2017 | fyear==2018

*The variables that we have pre-treatment are: gaap_etr_w finance r_and_d_w leverage_w foreign_operations_w size_w nol_w intangibles_w gross_ppe_w roa_w market_to_book_w

* Propensity Score:

probit TREAT gaap_etr_w finance r_and_d_w leverage_w foreign_operations_w size_w nol_w intangibles_w gross_ppe_w roa_w market_to_book_w

predict pscore, $\mathrm{p}$

* Common support between treated and controls

sum pscore 
sum pscore if TREAT $==0$

sum pscore if TREAT $==1$

* Propensity score graph

psgraph, bin(100) treated(TREAT) pscore(pscore)

* Verifying if pscore is balanced in groups

** Dividing the pscore into ten blocks and seeing if the pscore is balanced in each of the blocks:

xtile $b 1=$ pscore, nquantiles $(10)$

reg pscore TREAT if $b 1==1$, rob

reg pscore TREAT if $b 1==2$, rob

reg pscore TREAT if $\mathrm{b} 1==3$, rob

reg pscore TREAT if $b 1==4$,rob

reg pscore TREAT if $\mathrm{b} 1==5$, rob

reg pscore TREAT if $b 1==6$, rob

reg pscore TREAT if $\mathrm{b} 1==7, \mathrm{rob}$

reg pscore TREAT if $\mathrm{b} 1==8$, rob

reg pscore TREAT if $b 1==9$, rob

reg pscore TREAT if $\mathrm{b} 1==10$, rob

* Performing the Matching

* Nearest neighbor - 1 neighbor - with replacement

psmatch2 TREAT, pscore(pscore) n(1) outcome(gaap_etr_w)

* See the created variables:pscore _pscore_id_n1_nn_pdif

br pscore_pscore _id_n1_nn_pdif

* Nearest neighbor - 1 neighbor - no replacement

psmatch2 TREAT, pscore(pscore) n(1) noreplacement outcome(gaap_etr_w)

* Nearest neighbor - 5 neighbors - with replacement

psmatch2 TREAT, pscore(pscore) n(5) outcome(gaap_etr_w)

* Nearest neighbor - 10 neighbors - with replacement

psmatch2 TREAT, pscore(pscore) n(10) outcome(gaap_etr_w)

* Graphics to see the effect of Matching

* Graph before matchinhg

twoway (kdensity _pscore if TREAT==1) (kdensity _pscore if TREAT==0)

* Graphafter matching

twoway (kdensity_pscore if TREAT==1 [aw=_weight]) (kdensity_pscore if TREAT==0 [aw=_weight]) if _weight $>0$ \&_weight!=. 
//Propensity Score Matching - CASH ETR (Sarbanes Oxley Act)

* The variables that we have pre-treatment are: cash_etr_w finance r_and_d_w leverage_w foreign_operations_w size_w nol_w intangibles_w gross_ppe_w roa_w market_to_book_w

* Propensity Score:

probit TREAT cash_etr_w finance r_and_d_w leverage_w foreign_operations_w size_w nol_w intangibles_w gross_ppe_w roa_w market_to_book_w

predict pscore $2, \mathrm{p}$

* Common support between treated and controls

sum pscore 2

sum pscore 2 if TREAT $==0$

sum pscore 2 if TREAT $==1$

* Propensity score graph

psgraph, bin(100) treated(TREAT) pscore(pscore2)

* Veryfing if pscore is balanced in groups

** Dividing the pscore into ten blocks and seeing if the pscore is balanced in each of the blocks:

xtile b2 = pscore2, nquantiles $(10)$

reg pscore 2 TREAT if $b 2==1$, rob

reg pscore 2 TREAT if $b 2==2$, rob

reg pscore 2 TREAT if $b 2==3$, rob

reg pscore 2 TREAT if $b 2==4$, rob

reg pscore 2 TREAT if $b 2==5$, rob

reg pscore 2 TREAT if $\mathrm{b} 2==6, \mathrm{rob}$

reg pscore 2 TREAT if $b 2==7$, rob

reg pscore 2 TREAT if $b 2==8$, rob

reg pscore 2 TREAT if $b 2==9$, rob

reg pscore 2 TREAT if $b 2==10$, rob

* Performing the Matching

* Nearest neighbor - 1 neighbor - with replacement

psmatch2 TREAT, pscore(pscore2) n(1) outcome(cash_etr_w)

* View the created variables:

pscore_pscore_id_n1_nn_pdif

br pscore_pscore_id_n1_nn_pdif

* Nearest neighbor - 1 neighbor - no replacement

psmatch2 TREAT, pscore(pscore2) n(1) noreplacement outcome(cash_etr_w)

* Nearest neighbor - 5 neighbors - with replacement

psmatch2 TREAT, pscore(pscore2) n(5) outcome(cash_etr_w) 
* Nearest neighbor - 10 neighbors - with replacement

psmatch2 TREAT, pscore(pscore2) n(10) outcome(cash_etr_w)

* Graphics to see the effect of Matching

*Graph before matching

twoway (kdensity pscore 2 if TREAT==1) (kdensity pscore 2 if TREAT==0)

*Graph after matching

twoway (kdensity pscore 2 if TREAT==1 [aw=_weight] $)($ kdensity pscore 2 if TREAT==0 [aw=_weight])

if _weight $>0$ \&_weight! =.

$* *$

//To save database

save Base_updated.dta

log close 